Portland State University

PDXScholar

6-12-1997

\title{
The Minimal Role of Legal Traditions at the International Court of Justice
}

Kalley Rae Aman

Portland State University

Follow this and additional works at: https://pdxscholar.library.pdx.edu/open_access_etds

Part of the Political Science Commons

Let us know how access to this document benefits you.

\section{Recommended Citation}

Aman, Kalley Rae, "The Minimal Role of Legal Traditions at the International Court of Justice" (1997). Dissertations and Theses. Paper 5216.

https://doi.org/10.15760/etd.7092

This Thesis is brought to you for free and open access. It has been accepted for inclusion in Dissertations and Theses by an authorized administrator of PDXScholar. Please contact us if we can make this document more accessible: pdxscholar@pdx.edu. 
The abstract and thesis of Kalley Rae Aman for the Master of Science in Political Science were presented June 12, 1997, and accepted by the thesis committee and the department.

COMMITTEE APPROVALS:

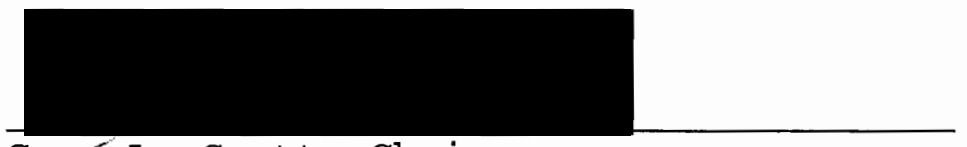
Gapy L. Scott, Chair

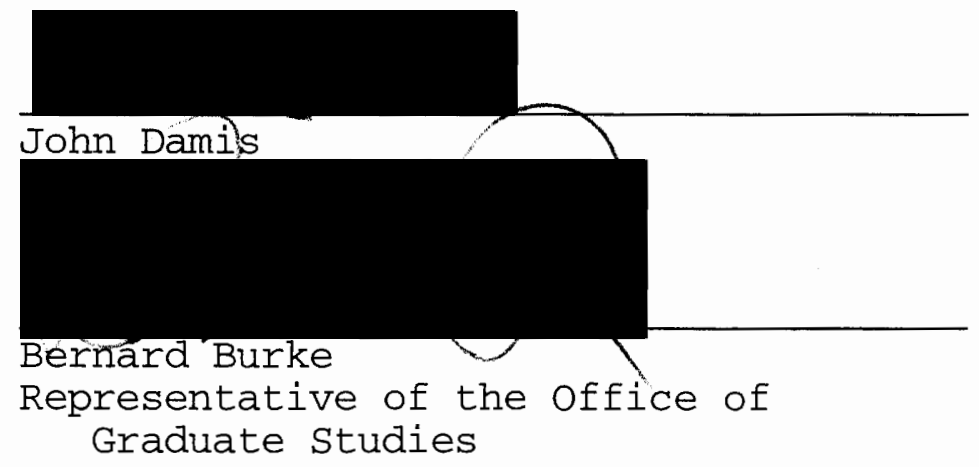

DEPARTMENT APPROVAL:

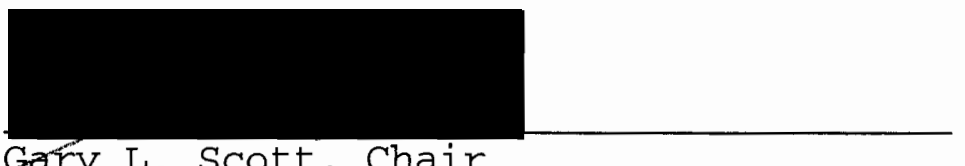

Gary L. Scott, Chair

Department of Political Science
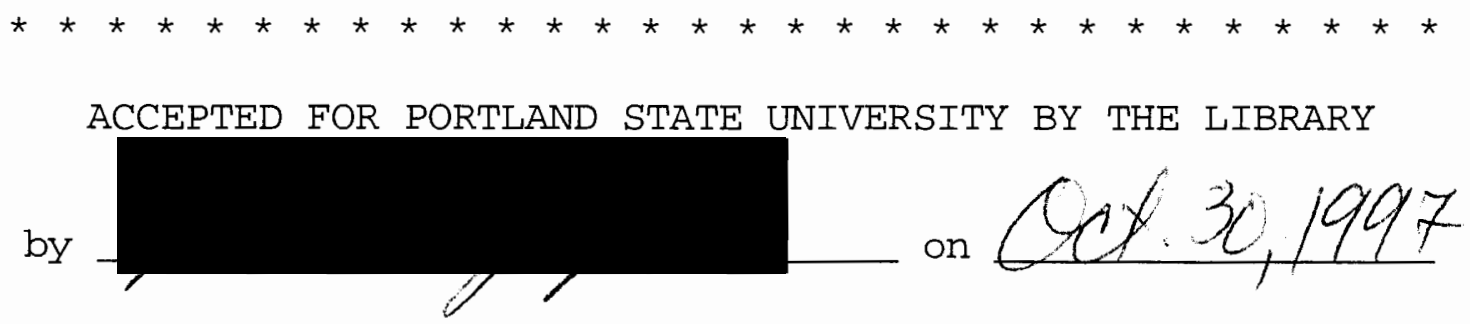
ABSTRACT

An abstract of the thesis of Kalley Rae Aman for the Master of Science in Political Science presented June 12, 1997.

Title: The Minimal Role of Legal Traditions at the International Court of Justice

International legal scholars and lawyers have dedicated much thought and energy to enhancing their understanding of how judges at the International Court of Justice (ICJ) come to decide cases the way they do. Although these studies of judicial behavior at the ICJ have provided insight into international judicial decision-making, still little is known about how international judges reach decisions.

This project was an attempt to improve upon the explanations, given thus far, for the decisions made by ICJ judges in the cases brought before the court. In this study I tried to ascertain whether and to what extent the legal tradition under which an ICJ justice has been educated and trained to practice law determines how she or he finds and applies the law in an international dispute. 
I also sought to answer the following question: Do the civil law and common law traditions differ in enough ways or to such a great extent as to render them distinct from one another?

I began by examining the world's three principal legal traditions, civil law, common law, and socialist law, according to three criteria common to macrocomparative surveys on legal tradition: history, the conception of law, and the institutional elements of a legal system.

The decisions of three ICJ cases were analyzed with a view to determining whether the justices voted along lines of legal tradition and/or discovered and applied the law in a manner typical of the legal tradition under which they were educated. From the analysis I concluded that legal tradition was not a significant variable in the judicial decision-making at the ICJ. The examination of the cases also indicated that the common law and civil law traditions appear to converging in so far as they have adopted the methods of the other tradition yet still diverging as they continue to reveal traditional differences. 
THE MINIMAL ROLE OF LEGAL TRADITIONS AT THE INTERNATIONAL COURT OF JUSTICE

by

KALLEY RAE AMAN

A thesis submitted in partial fulfillment of the requirements for the degree of

\author{
MASTER OF SCIENCE \\ in \\ POLITICAL SCIENCE
}

Portland State University

1997 
TABLE OF CONTENTS

page

I. Introduction. . . . . . . . . . . . . . . . . . . . 1

Legal Traditions Around the World . . . . . . . . 12

II. The Principal Legal Traditions: Civil Law, Common

Law, and Socialist Law . . . . . . . . . . . 19

The Civil Law . . . . . . . . . . . . . . . . 19

The Common Law Tradition . . . . . . . . . . . . 32

Are the Civil Law and Common Law Traditions

Converging? . . . . . . . . . . . . . . . . . . 45

Implications for International Law . . . . . . . . 51

The Socialist Legal Tradition . . . . . . . . . . 56

The Socialist Perspective of International Law . . 68

III. The International Court of Justice . . . . . . . . 77

ICJ I: The Case Concerning Right of Passage Over Indian Territory, Judgment (12 April 1960) . . . . 81

IV. ICJ II: The North Sea Continental Shelf Cases, Judgment (20 February 1969) . . . . . . . . . . . . 111

V. ICJ III: The Case Concerning Certain Phosphate Lands in Nauru, Judgment (Preliminary Objections)

(June 26, 1992) . . . . . . . . . . . . . . . . . . 141

VI. Conclusion . . . . . . . . . . . . . . 177

Are Common Law \& Civil Law Really Different? . . . 184

Notes . . . . . . . . . . . . . . . . . . 189

Works Cited.................. 216 


\section{CHAPTER ONE}

\section{Introduction}

For years, legal scholars and others taking an interest in law have theorized about how judges make decisions. Some have hypothesized that judges rule according to their own political or social interests ${ }^{1}$, others have argued that judges allow only the law and relevant legal principles to influence their legal reasoning and decision-making in the cases that are brought before them. ${ }^{2}$ Still, many other writers have suggested that it is a combination of factors, including the judge's socio-economic background, his or her legal education and political and social interests, and her or his sense of responsibility to uphold the law that contribute to the process of deciding a legal dispute. ${ }^{3}$

Legal scholars and international lawyers have dedicated much thought and energy to enhancing their understanding of how judges at the International Court of Justice come to decide cases the way they do. ${ }^{4}$ Undoubtedly, few would find the reasons for these studies surprising. International lawyers, particularly those 
who represent countries with disputes before the court, have an interest in understanding how the justices who are deciding the cases will reach a conclusion about the facts of the conflict and the law that governs it; the better international lawyers can predict the way justices will decide, the greater their hopes of reaching a desirable outcome.

One might suppose also that legal scholars or enthusiasts of international law seek knowledge of the legal reasoning of ICJ judges so that they may improve upon their explanations and predictions of ICJ decisions. By gaining insight into the decision-making process at the ICJ, scholars and enthusiasts of the law contribute to their own pursuit of intellectual development and that of the academic community.

This thesis endeavors to make such a contribution; it is an attempt to improve upon the explanations, given thus far, for the decisions made by ICJ judges in the cases brought before the court. As stated at the outset, many arguments are advanced to explain judicial behavior. However, when one looks toward the ICJ, one finds that past studies have not shed enough light on the decision- 
making process at the ICJ. Little is yet known about how international judges reach decisions.

In this thesis I will try to ascertain if and to what extent the legal tradition under which an ICJ justice has been educated and trained to practice law determines how she or he finds and applies the law in an international dispute. This will be accomplished through the case study method. I have chosen three cases for analysis: The Right of Passage case (India V. Portugal) ${ }^{5}$, The North Sea Continental Shelf Cases (Denmark/The Netherlands V. Germany $)^{6}$, and The Case Concerning the Phosphate Lands in Nauru (Nauru V. Australia).?

These three disputes were chosen from among the roughly 76 contentious cases rendered by the ICJ because they each represent a period of the Court's activity that is distinguishable from the next. Gary scott and Karen Csajko examined the history of the Court's activity and found, based on the political and legal landscape since the inception of the ICJ, that its history could be logically divided into three eras: ICJ I (1946 through 1962), ICJ II (1963 through 1985) and ICJ III (1986 to present). ${ }^{8}$ 
These particular cases were chosen from the era they represent because the decisions were the most divisive of the period. ${ }^{2}$ In other words, the decisions in these cases were not only split, i.e. dissenting and separate opinions were cast, but were widely split with, in some cases, the majority of the justices opting out of the Court's judgment through separate opinions, declarations, or dissents.

I have chosen to analyze these decisions on the basis of legal traditions for two reasons. First, little research has been done on the effect that legal education and training has on the performance of ICJ justices. Lyndell Prott offers a relatively brief investigation of the influence of legal education on the judges; however, his inquiry extends to only two cases and he chooses these because they stand out as examples of this type of influence. ${ }^{10}$ In this project, I am attempting to improve upon Prott's methodology so that I may draw informative conclusions about the decision-making at the ICJ.

Second, it seems that inquiries into other factors that are typically cited as significant variables in judicial reasoning and decision-making, e.g. socio- 
economic background of the judge, political interests, and ethical or moral concerns, have not substantially improved the understanding of scholars and lawyers on how decisions are reached at the ICJ. While much of the research on judicial behavior at the ICJ is insightful and enlightening, it still appears that not enough is known about the process of reaching a judgment at the World Court. ${ }^{11}$

I should state at the outset that I do not propose to draw grand conclusions about how judges at the ICJ reach a judgment. Instead, I will heed the advice of experts in the field of judicial behavior who often issue warnings about placing too much emphasis on one variable or hastily separating one variable in the judicial decision-making process from the multitude of potential others. One follower of the ICJ states the challenge ahead of me nicely:

Naturally one cannot expect to determine in what exact proportion each of these factors has influenced the judge's thinking. It would be rash in the extreme to try to calculate the exact proportion of each element of personal experience on a judge's mentality, or to try to discover their precise degree of influence on a particular decision - such influence being essentially incalculable. The aim of this analysis is only to expose these factors in the hope that this will create more 
awareness of their influence. ${ }^{12}$

\section{WHAT IS A LEGAL TRADITION?}

Simple observation teaches us that law varies across the globe. Legal principles, legal processes, legal institutions, and legal structures all differ from one political society to the next. ${ }^{13}$ The divergence of law and legal mechanisms is perhaps most visibly apparent in the diversity of regional, national, and municipal laws in force throughout the world. ${ }^{i 4}$

Each sovereign state has, of course, its own national legal system. These legal systems are essential for the maintenance of order in these states and remain a cornerstone of their sovereignty. Within these systems, states enact laws and enforce them according to the principles and procedures they desire.

Less observable is what is known as a legal tradition. Legal traditions encompass much more than the laws and legal machinery of a single state. As we will see in the following pages, legal traditions provide the broader theoretical framework for the discrete national legal systems. More specifically, they embody the historical and cultural background within which groups, 
whether states, localities, tribes, or collectivities, approach and implement the law. They are, as one scholar has nicely put it,

..a set of deeply rooted, historically conditioned attitudes about the nature of law, about the role of law in the society and the polity, about the proper organization and operation of a legal system, and about the way law is or should be made, applied, studied, perfected, and taught. The legal tradition relates the legal system to the culture of which it is a partial expression. It puts the legal system into cultural perspective. ${ }^{15}$

A legal tradition, then, "is not a set of rules of law about contracts, corporations, and crimes,"16 rather it is a disposition towards law which is influenced and informed by the culture in which it operates. It is the context under which specific rules of law are made and implemented, thus the legal tradition is not only prior to the rules about "contracts, corporations, and crimes" but, more importantly, it is the theoretical point of origin for these laws.

Craig Lawson offers a schema for simplifying legal systems which may also serve as a useful aid for understanding the idea of a legal tradition. ${ }^{17}$ Using a technique which often appears in macrocomparative surveys, Lawson identifies four features that are 
commonly used to compare legal traditions. These are 1) history;

2) conception of law; 3) structural elements of the formal system of laws; and 4) institutional elements of the legal system. ${ }^{18}$ Although I will not, at this point, proceed to examine each legal tradition according to these features, it seems that by providing an explication of each of these four features, one might gain a better grasp on the notion of a legal tradition.

1. History: Each legal tradition has its own history, that is, the ideas that we hold today towards law are not entirely our own. The history of a legal tradition is a narrative of the ideas and events that have shaped the contemporary legal system. John H. Merryman notes that "law is among other things, an expression of a culture; ideas about law are part of the intellectual history of a people." ${ }^{19}$ Granted, an exploration into the history of a legal tradition may not directly tell us everything we need to know about contemporary policies, laws, and legal mechanisms, ${ }^{20}$ but it does set the theoretical stage for the contemporary legal situation. 
2. A Conception of Law: The second feature noted above is not consciously developed by those who adhere to a legal tradition. ${ }^{21}$ As Lawson explains, a conception of law can be defined as "an underlying set of assumptions about the nature of law and its role in organizing social life."22 It is a fundamental attitude towards law that is both "predominant and historically deep-rooted."23 The conception of law has overarching significance for legal systems and those groups and individuals it governs since it will "color all the workings of the legal order." ${ }^{24}$

The remaining two features reflect a concern with less abstract aspects of a legal tradition.

3. The Formal Elements of A Legal System: This typically refers to the individual rules of law in legal systems. However, comparatists have found that the organization of legal systems into larger groupings on the basis of more general and structural elements is more practical and, arguably, more valuable than comparing the individual rules of a system..$^{25}$ "The similarity of rules is in most cases an unreliable indicator of the 
convergence or divergence of the legal system, "Merryman notes. "The rule ordinarily symbolizes far more than its bare text states. ${ }^{26}$ Rules do not say anything about "legal extension, legal penetration, legal culture, legal structures, legal actors and legal processes."27 And as Lawson points out, rules and doctrines are "the least enduring and most superficial elements of legal systems." 28 Brierly agrees, stating that "a system of law is something more than merely the sum total of all the rules valid in a given country and at any given time." 29 Grouping legal systems into traditions involves taking into consideration "constant elements" rather than the "less stable rules found in the law at any given moment." 30 Hence, structural elements of legal systems are most often chosen for the purposes of macrocomparative study of legal traditions; these are considered to be enduring elements of a legal system and reflect the continuity of law. ${ }^{31}$ The following structural elements are most often chosen for the purposes of macrocomparative study: the major divisions or branches of a body of laws, its fundamental or pervasive concepts, and its terminology. ${ }^{32}$ 
4. The Institutional Elements of A Legal System: These are "the animating forces in a legal system." 33 They include the Courts, legislatures, associations of lawyers, and other legal processes that can be found within the legal structure. ${ }^{34}$ In order to learn more about a legal tradition, the comparatist might ask what role legislatures play in the particular legal systems that tradition governs. Or she might make inquiries into the part that lawyers and other advocates play in the legal systems .

A legal tradition, then, is a narrative of a culture's ideas and attitudes towards law and its role in society. These attitudes are reflected in the structure of the legal system as well as its institutions. To build a legal system, a society must know in advance what it wants from the rule of law; it must have formed an idea of how law ought to be or is created; it must have a conception of the type of relationship its members will have with the law; and it must have some notion of how it would like to see law implemented and enforced. In short, the society must have expectations about the 
functions of the legal system and the principles upon which it will operate.

But these expectations do not appear overnight, in fact, they can be traced back to ideas that are hundreds, even thousands of years old. It is the history of these ideas, and the cultural context within which they are developed, which forms the legal tradition and, subsequently, the mindset with which a society approaches the law.

\section{LEGAL TRADITIONS AROUND THE WORLD}

There are three principal legal traditions in the world today: the civil law tradition, the common law tradition and the socialist tradition of law. ${ }^{35}$ The civil law tradition is the dominant legal tradition in most parts of Western Europe, all of Central and South America, many parts of Asia and Africa and in a few enclaves of the common law world - Quebec, Puerto Rico, and Louisiana. ${ }^{36}$ The United States, Great Britain, Ireland, Canada, Australia, and New Zealand all adhere to the Anglo-Saxon common law tradition. ${ }^{37}$ Parts of Asia and Africa have also been substantially influenced by the 
common law tradition. ${ }^{38}$ The Socialist law tradition operates in the states of the former Soviet Union and in those Eastern European states that once constituted part of the Soviet Bloc. ${ }^{39}$

As we shall see, each of these three traditions is of European origin. Merryman explains that they are all

closely allied to the development of European civilization. They express ideas and embody institutions which have been formed in the western historical and cultural context. ${ }^{40}$

The civil law and common law traditions in particular have developed in a similar historical and cultural setting. In fact, some comparatists argue that the histories of these two traditions and the conceptions of law they hold are so alike that to speak of them as two distinct legal traditions is misleading. ${ }^{41}$ If this is the case, i.e. if the civil and common law traditions are really one in the same except for some minor differences, then this project is in jeopardy, for most of the judges at the ICJ have been educated and trained under a common law or civil law system. In other words, if the legal traditions do not diverge in ways that might matter to 
the decision-making of justices, then this study seems pointless. However, the contention that the civil and common law traditions share virtually all of their fundamental characteristics and thus should not be thought of as two distinct approaches to law is simply that - a contention. There are others who argue that the traditions diverge in both subtle and explicit ways which are reflected in the institutions, processes, and structure of the legal systems. ${ }^{42}$

In order to come to any conclusion about the similarities or differences between legal traditions, an examination of the traditions must be undertaken using a defined set of criteria. I will once again borrow the criteria used by Lawson in his comparative study of civil law and common law legal traditions: history, conception of law, structural elements of the formal system of laws, and institutional elements of the legal system. ${ }^{43}$ Lawson explains that the comparison of legal traditions involves identifying particular features:

One must find a taxonomy which compares fundamental features - those which are more likely to be enduring and widely dispersed - and features which broadly represent the range of laws and institutions within a legal system. ${ }^{44}$ 
The four features proposed by Lawson are useful tools for analysis; they provide enough generality to make possible a comparison of what are potentially very diverse legal traditions yet they establish fairly clear guidelines for determining what can or cannot be incorporated into the analysis. ${ }^{45}$ In other words, comparison based on the four features alone allows for manageability over a wealth of information some of which is relevant to the analysis and some of it not. These features appear to be relevant to the purpose of this project, i.e. determining the influence of legal tradition on judicial decision-making at the ICJ, for two reasons. First, they comprise what are the enduring and fundamental features of a legal tradition. As discussed above, comparatists agree that an attempt at comparison of legal traditions based on changing and unstable elements, for instance the individual rules of legal systems, fails to satisfy the standards of comparative scholarship. ${ }^{46}$ Second, application of the set of criteria proposed by Lawson to this project makes it a manageable endeavor.

In my own analysis I will, however, omit the third feature, structural elements of the formal system of 
laws. As discussed above, comparatists discourage drawing conclusions about legal traditions or legal systems from a comparison of the particular rules of a legal system. They argue that a more fruitful endeavor would take into account the structural features of the system. But it seems that for the purpose of this thesis, an exploration into structural features is unnecessary; an analysis of the traditions based on the other three features will suffice.

From the examination of the traditions we can hopefully begin to find answers to two questions. First, do the traditions differ in enough ways or to such a great extent as to render them distinct from one another? Second, do the legal decisions at the ICJ reflect a commitment to the principles and procedures of a legal tradition and if so can legal education and training of justices greatly enhance one's power to explain and predict judicial decision-making at the ICJ?

Before turning to an examination of the civil law, common law, and socialist law traditions, I would like to point out that these are not the only legal traditions represented throughout the world. Other major religious 
and nonwestern legal traditions include Islamic law, Hindu law, Jewish law, Chinese and Japanese (and Korean) law, and the variety of indigenous African legal traditions usually summed up as African customary or tribal law. ${ }^{47}$ Although these nonwestern legal traditions are of equal importance to the international legal community and the ICJ as the Western legal traditions, they will not be included in this study. This examination will encompass only civil law, common law, and socialist law as the justices that have sat at the ICJ have overwhelmingly been educated and trained under one of the three Western legal traditions.

Finally, one caveat will be issued before proceeding to the discussion of the legal traditions. Setting aside for the moment the question of whether or not the legal traditions are truly distinct from one another, one must still show caution when trying to place ideas, concepts, institutions, structures, etc. into categories. Taxonomies are useful for the purposes of explaining phenomena; however, they do not exist apart from our conception of that phenomena. Legal traditions, then, are a theoretical construct; they represent the scholar's 
need to organize and understand phenomena. In fact,

there is no such thing as the civil law system, the common law system, or the socialist law system. Rather, there are many different legal systems within each of these three groups or families of legal systems. But the fact that different legal systems are grouped together under such a rubric as "civil law," for example, indicates that they have something in common, something that distinguishes them from legal systems classified as "common law" or "socialist law." 48

It is to these commonalties between and among legal

systems that I now turn. 


\section{CHAPTER TWO}

\section{THE THREE PRINCIPAL LEGAL TRADITIONS: CIVIL LAW, COMMON LAW, \& SOCIALIST ILAW}

The student making a comparison of the methods of legal thinking in the common law and the civil law must be constantly on his guard against one-sided views, for they are too easily adopted by the superficial observer in this area. ${ }^{49}$

\section{THE CIVIL LAW}

\section{$\underline{\text { HISTORY }}$}

The civil law tradition is the oldest of the three principal legal traditions; it can be traced back to Justinian's Corpus Juris Civilis of the sixth century A.D. ${ }^{50}$ In an effort to reclaim and reorganize the Roman legal system, the Roman Emperor Justinian prepared an authoritative text on the Roman Civil Law. Although the Corpus Juris Civilis was influential during the existence of the Roman Empire, after the empire's dissolution it fell into disuse until the renaissance of the 11 th and 
12th centuries. Thus, the birth of the civil law tradition is typically considered to have been in the middle ages with the revival of the Corpus Juris Civilis by the legal scholars of the Renaissance.

The Corpus Juris Civilis became the primary subject of study at the Italian legal universities, including Bologna. Merryman offers two reasons for the Italians' fascination with Justinian's compilations. First, the Renaissance was marked by a heightened interest in the Holy Roman Empire. ${ }^{51}$ Since the Corpus Juris Civilis was written by a Holy Roman Emperor, it was thought of as "imperial legislation" conferred upon the people by the authority of both the pope and the emperor. ${ }^{52}$ Second, with the renewed faith in the potential of reason, the twelfth century Italians hailed the Corpus Juris Civilis as a piece of "written reason", a work of intellect superior to the laws established by the barbaric Germans. ${ }^{53}$ The prominence of the Corpus Juris Civilis rose as the legal universities of Bologna and other Italian cities became the foremost institutions for legal study. ${ }^{54}$ As men from all of Europe flocked to the Italian universities to study law and then returned home to practice it, the 
Corpus soon evolved into a body of law common among the European nations.

Although the jus commune, as it is known, was not a uniform body of law applicable to all of the nations of Europe, it was similar to the law of the Holy Roman Empire in that it was created to overcome the diversities across the continent. ${ }^{55}$ It intended to provide jurists with a common language and method which oriented them in the search for just solutions. ${ }^{56}$ As Rogowski phrases it, "the civil law is not a distinct field of law, but an umbrella concept for legal cultures on the European continent. . " 57

The development of the jus commune was greatly affected by the events that unfolded in European society in the $16 \mathrm{th}, 17 \mathrm{th}$, and $18 \mathrm{th}$ centuries. The predominance of Justinian's text diminished as the intellectual revolution that framed the American and French revolutions made its mark on the civil law.

The influence of the Enlightenment on the development of the jus commune is apparent in changes such as the glorification of the secular state, the exaggerated emphasis on private property and liberty of 
contract, the abolition of feudal obligations and relationships, and nationalism. ${ }^{58}$ The new found principles of equality of persons and natural rights to property, liberty and life reflect the enlightenment preoccupation with secular natural law. ${ }^{59}$ The fear of government instilled by this movement and its valorization of personal liberties is manifested in the principle of separation of powers and, in France, in the limiting of the role and power of the judiciary. ${ }^{60}$ Finally, the rationalism prevalent in 18 th century Europe is evidenced in the codification of civil law into a "coherent, systematic form. "161

The nineteenth century witnessed a fragmentation of the civil law, with the European states making national law exclusive to their own states. The civil codes formulated by the European states, particularly France, embodied principal concepts from Roman civil law. To this day, the sovereign states of Europe have distinct national legal systems. Nonetheless, the influence of the jus commune is, according to some scholars, undeniable: 
But what binds such nations together is that these indigenous legal institutions have been combined with the form and substance of Roman civil law, under the influence of the jus commune. The Roman influence is very great; the native legal contribution, while substantial, is generally of subsidiary importance. It does not go to such matters as basic legal attitudes and notions, or to the organization and style of the legal order. These are drawn from the older, more fully developed and sophisticated Roman civil law tradition. ${ }^{62}$

According to this view, the law of the individual European states is first, a product of jus commune and second, a creation of each of the states.

\section{CONCEPTION OF THE LAW}

As the historical survey indicated, the civil law tradition was born out of the Renaissance scholars' interest in an authoritative rule of law based on reason. It was later reborn out of the Enlightenment thinkers' excitement about natural law, the idea of equality of persons, and again, reason. Because of the persistent commitment to principle and the human capacity to reason evidenced in the history of the civil law, it should come as no surprise that civil law lawyers and scholars have historically placed great faith in abstraction. ${ }^{63}$ 
Law is, in the civil law world, a theoretical enterprise and hence is often referred to as a "law of scholars."64 Law is conceived of as a rational process; logical, rigid and clear. ${ }^{65}$ The codes embody this process, they represent an attempt to "rationalize the answers and anticipate legal problems before they arise." 66 The codes manifest the civilian lawyers' conception of law, they are "the materialization of a legal philosophy" and a "solidification of society's ever changing morals into a fixed set of rules." ${ }^{67}$ The code, then,

is a construction of the mind designed to impose a rational and well defined legal order on a particular society... what you have is a snapshot, a frozen moment in time, of your rights and obligations as they apply to you and to your relations with others and with society. ${ }^{68}$

Civil law reasoning is deductive. From the materials of law (statutes, regulations, etc.) the civilian lawyer deduces universal, inherent principles and relationships. The legal process in civil law countries is syllogistic; as one lawyer has noticed, civilian law lawyers engage in what he calls "drawer methodology. "69 When thinking through a legal problem, one element of reason leads logically to another and so forth 
until the answer is found in the appropriate code. ${ }^{70}$ The process of legal reasoning is similar to pulling drawers, one by one, until one drawer contains the answer to the problem. ${ }^{71}$

The civilian lawyer is not searching for the drawer with the best answer. She or he is on a quest for the right answer. ${ }^{72}$ In civil law, the lawyers do not search for a partisan agreement, instead they search for the general rule that governs the factual situation at issue. ${ }^{73}$ Each adjudication involves the application of some interpretation of the code to a particular set of facts. ${ }^{74}$ Hence, the facts play a subsidiary role to the rule. In fact, the codes are intended to be fully comprehensive so that the facts of the case don't preclude a rational resolution:

legal technique involves the interpretation of statutory texts, analysis of concrete problems so as to "fit them into the system" conceptually. ${ }^{75}$

It is assumed in the civil law world that the written codes contain the answer to a dispute and the goal of those in the legal process is to find the answer that, on principle, is the right one. Indeed justice requires 
that the civilian lawyer seek to refer facts back to supposed universal principles.

INSTITUTIONAL ELEMENTS OF THE LEGAL SYSTEM: A LOOK AT LEGAL EDUCATION \& TRAINING AND THE ROLE OF JUDGES

Legal Education:

What is perhaps most surprising to the common law observer is that legal education in the civil law world is a general education at an undergraduate university. ${ }^{76}$ This observation is not unimportant, however, for as will be shown, the different contexts for earning a law degree in common law and civil law countries signify even greater differences between legal education under these two traditions.

Glendon, Gordon and Osakwe point out that the greatest divergence in the legal education of these two traditions appears in the manner in which the student is initiated into the study of law. Mirjan Damaska identifies three enduring features of a continental legal education: instruction in the grammar of law, a presentation of the most important fields of law, and 
training in legal reasoning. ${ }^{37}$

The instruction in the grammar of law involves the analysis of legal concepts followed by the creation of more general concepts and then a study of the relationship of these concepts. ${ }^{78}$ It is a "step by step conceptual digestion of the law that results in a network of precise interrelated concepts, broad principles and classificatory ideas. "79

The panoramic presentation of the most important fields of law, the second feature of legal education in civil law countries, emphasizes not particular legal facts but the abstract legal issues that worry civilian lawyers and scholars. Because the civil law legal education is set in a general university and is considered more of a general education than a professional education, it is also more academic than practice-oriented. Instruction is more philosophic in nature and less concerned with practical legal problems and resolutions. ${ }^{80}$ students are introduced to the study of law through a "systematic overview of the framework of the entire legal system." 81

Generally, instructors tend to be more concerned 
with substantive knowledge and information than procedural questions. ${ }^{82}$ Lecture is the primary method of teaching law and class materials usually consist of treatises and codes. ${ }^{83}$ To the professor, a student's sensitivity towards logical consistency over wide areas of the law is an indication of a good lawyer in the future. ${ }^{84}$ Law is regarded, in varying degrees, as a science with the professor knowing the truth and imparting it to the students. ${ }^{85}$

Students are taught patterns of legal reasoning which correspond to the conception of law that predominates in civil law legal systems. In the United States we have developed the phrase "to think like a lawyer" to refer to a type of approach to a problem. This phrase does not carry the same connotation in civil law countries. Students are taught not to problem-solve and develop the best argument but to look for the correct answer to the legal problem. ${ }^{86}$ They are not instructed in the art of argumentation; they are educated to reason through the problem for its logical conclusion. Merryman notes that the principal object of scholarship in the civil law tradition is to build a 
science or theory of 1 aw. ${ }^{87}$ The legal education in civil law societies is reflective of that objective. As Damaska observes, the lawyer educated on the continent will see this objective betrayed with an emphasis on factual questions and too much concern about justice in a given case. ${ }^{88}$ Thus, the practice of law is downplayed during one's legal education and a comprehensive understanding of the legal system and the principles upon which it is founded are emphasized. ${ }^{89}$

Upon graduation, the law graduate in a civil law system has a number of options. However if she or he chooses to enter the legal profession as an attorney, more practical training will be required. ${ }^{90}$ Legal education on the continent is not intended to prepare students for life as a lawyer. As was pointed out in the examination, civil law is a "law of scholars" and the legal education at the university perpetuates that conception.

Role of Judges:

Traditionally, the part that judges play in civil law societies has been minimal in comparison with other legal traditions. ${ }^{91}$ The position has historically been a 
bureaucratic one offering little flexibility or creativity for its holders. ${ }^{92}$ The civil law judge is thought of as a civil servant with the duty of applying the appropriate legislation to a legal conflict. ${ }^{93}$ She or he is part of a professional judiciary and is treated with the same respect as other public servants. ${ }^{94}$

A career in the professional judiciary can begin as soon as one graduates from law school. ${ }^{95}$ The process of becoming a judge is relatively uncomplicated: one applies for the position, takes state examinations, and, assuming the application is accepted and the exams passed, becomes a judge. ${ }^{96}$ Before long, she or he will be deciding minor Cases. ${ }^{97}$

In civil law societies, judicial decision has involved little more than the application of a particular written rule of law to the facts. ${ }^{98}$ Thus the power of the judge to influence the development of law has been virtually absent. In fact, in civil law legal systems judges are almost anonymous. ${ }^{99}$ Working within a legal tradition which valorizes the legal theory of scholars, civil law judges look to the writings of academics for arriving at decisions. ${ }^{100}$ Academics interpret the law and 
judges, when adjudicating a dispute, look to these interpretations and apply them accordingly. ${ }^{101}$ The authority to apply precedent to a pending legal dispute is given to the judge only after the principles in the precedent have "hardened into customary law."102

Judgments on the continent are not personalized and are rarely divided. As Zweigert and Kotz explain, judgments

should primarily be impersonal acts of state which parade the majesty of the law in front of citizens in awe of authority. ${ }^{103}$

The continental judge is discouraged from writing dissenting opinions. ${ }^{104}$ The judgment of the civil law court is considered authoritative, unquestionable, and final. ${ }^{105}$ Because each legal problem is supposed to have one right answer, civil law societies value unanimous court decisions. Hohmann notes that there is a reluctance in civil law countries to think of courts as "participants in an ongoing debate" about legal problems and their solutions. ${ }^{106}$ He explains that the civil law style is for decisions to flow from an impersonal, unified authority. ${ }^{107}$

According to Merryman, the process of judicial 
decision can be fit into a formal syllogism of scholastic logic. ${ }^{108}$ The code contains the major premise, the facts of the case serve as the minor premise, and the conclusion follows from the two. ${ }^{109}$ As he sees it, the civil law judge is "an operator of a machine designed and built by legislators"110; she or he applies what others create. The others, Merryman argues, are the legislators whose names we recognize (Justinian and Napoleon) and scholars whose works we might have read (Gaius, Irnerius, Bartolus, Mancini, Edomat, Pothier, Savigny). ${ }^{111}$ Judges in civil law countries have not enjoyed the same status as these historic figures nor have they left a comparable legacy in the civil law tradition. ${ }^{112}$

\section{THE COMMON LAW TRADITION}

\section{$\underline{\text { HISTORY }}$}

One third of the earth's population lives in a region where common law has made its mark. ${ }^{113}$ The influence of common law is found in former British colonies: The United States, Australia, Canada, India, Pakistan, South Africa, Ghana, Nigeria, Sierra Leone, Gambia, Liberia, Kenya, Uganda, and Tanzania. ${ }^{114}$ 
The origin of the common Law tradition is typically traced back to A.D. 1066, the date of the Norman Invasion when William I defeated the Anglo-Saxons in the Battle of Hastings. ${ }^{115}$ David and Brierly note, however, that it is not the actual act of conquest itself that altered the history of English Law. ${ }^{116}$ Instead, it was the strong, centralized, and experienced administrative organization, the "feudal pyramid" brought with the foreign occupation that forever changed the course of the Anglo-Saxon legal tradition. ${ }^{117}$

In connection with the increase in royal power in England that began with the reign of William $I$, the royal courts of justice became vested with an unprecedented range of jurisdiction which eventually included all of England. ${ }^{118}$ The king found that through an increase in the volume of disputes decided by the royal judiciary, he could increase profits for the kingdom, as litigants had to pay court fees, while extending his power and authority throughout the territory. ${ }^{119}$ Empowered by the King, this handful of royal courts with absolute jurisdiction developed, through their rulings, new procedures and new substantive law applicable to all 
Englishmen. ${ }^{120}$ This set of rules and laws came to be known as the common law.

During what is known as the "Age of Reform", philosopher Jeremy Bentham called for changes in the common law system. ${ }^{121}$ By the nineteenth century, the court system in England had become disorganized with courts claiming overlapping jurisdiction. ${ }^{122}$ This disorganization posed a major problem to the English legal system as it was the judicial decisions, not legislation, which served as the primary, and at that point in history the only source of law. The reform resulted in a transformation of the court system in England. A hierarchy of courts was established and jurisdiction was divided among them on the basis of particular areas of law. ${ }^{123}$

As the nineteenth century approached its end, several pieces of legislation were enacted in England which covered specific areas of commercial law. ${ }^{124}$ These "codifying statutes" were not comprehensive codes or regulations embodying societal values. Rather, they were "orderly presentations of existing rules which had been developed by the courts of common law."125 The legislation represented in written form the precedents set by the 
courts.

To this day there is no comprehensive codification of family law or the law of succession, law of contract or law of torts in England. ${ }^{126}$ The decisions of Courts remain the primary source of law. Historically, the legislation that has been promulgated has dealt with very specific questions rather than comprehensive areas of law. ${ }^{127}$ Further, these statutes are not revolutionary:

these statutes can only be understood against the background of the unwritten common law, for they use the concepts and categories and invariably presuppose the rights and doctrines which have been developed by the courts."

Like the states operating under the civil law tradition, those countries besides England that adhere to the common law tradition have put their own mark on their legal system. Although the English have historically demonstrated a distaste for law based on legislation, some common law countries, such as the United States rely on both case law and statutes as their sources of law. Nonetheless, case law still takes precedence over legislation as the judges in the United States have the authority to strike down legislation that runs counter to 
the Constitution or to judicial precedent.

Like the civil law tradition, then, the common law is a type of jus commune that sets the parameters for how a legal system which operates under its principles and procedures can be constructed.

\section{CONCEPTION OF LAW}

As one comparatist has observed, the transition from Roman law to English law represents the realization by humans that we have limitations and are incapable of answering the philosophical questions posed by Plato. The common law embodies this resignation and its followers, instead of asking "What is justice?" and striving to create law that manifests the answer, seek to find the best possible solution for each dispute. ${ }^{128}$ The principles of individualism and liberty stand out as foundational to the common law project. ${ }^{129}$ Common law favors rights rather than duties, emancipation rather than control and responsibility rather than paternalism. ${ }^{130}$ Common law is valorized for its liberal spirit:

Englishmen have thought of the Common Law as being the essential guarantee of freedom, serving to protect the citizen against the arbitrary inroads of absolute authority, 
a function of which on the continent is performed by the Constitution. ${ }^{131}$

Ironic as it may seem, the legal tradition that originated under a powerful monarchy and gives extraordinary power to judges to make law, is highly suspicious of authority. Common law follows from the notion that individuals have a right to contract freely and to procure property free from government intrusion. ${ }^{132}$ The aim of common law has not been to craft a comprehensive legal theory. Since its inception, the goal of common law actors has been to develop a procedural network whereby discrete disputes between conflicting interests could be resolved. ${ }^{133}$ Common law has historically been seen as being dominated by "procedural thinking" and, as was pointed out above, concerns about substantive law have been minimal compared to civil law countries. In fact, common law judges in England have shown to be disdainful of social legislation. ${ }^{134}$ In their eyes, social change is to be effected through court decisions. ${ }^{135}$

Although the aversion for legislation displayed by other common law states may not be as vehement as England's, the United States, Canada, Australia and the 
others still rely on precedent as the primary source of law. ${ }^{136}$ In these legal systems, the focus is on the facts surrounding a particular dispute and the precedents are categorized on the basis of such facts. ${ }^{137}$ Precedents are the substance of analysis in common law legal systems and law is often found through a knowledge of the facts of cases. ${ }^{138}$ A lawyer or judge who wants to find out what the law is on a particular matter looks for cases with similar facts and determines what the court said, and thus what precedent has been established. ${ }^{139}$

So unlike its counterpart on the continent, the common law tradition does not value law for its clarity, its logic, or for its conformity with standards of rationality. Law is not always clear in the common law world as it must be interpreted from court decisions which, even when dealing with what appear to be similar sets of facts, may contradict one another or apply different reasoning. Further complication arises out of the reliance on the facts of the case. Since each case is unique but may share similar circumstances with another, it becomes difficult to decide which cases are analogous to one another. The inevitable result of this 
process is disagreement in the legal community over how a court decision ought to be interpreted, conflicting ideas about which precedents are applicable to which cases, and most importantly, different ideas of what the law truly is.

Hence, in common law legal systems, law is conceived of as an exercise in argument with the best position becoming law. This is not to say that law in common law states is devoid of principle. The principles structure the parameters for argument and indeed often form the substance of it. As was noted above, the liberty of the individual is one principle that is presupposed in common law legal systems. Still, common law values the quest for practical solutions to practical problems encountered by free individuals; it is in this sense pragmatic. ${ }^{140}$ It does seek nor does it consider possible the quest for answers to enduring questions on the nature of the just society. 
INSTITUTIONAL ELEMENTS OF THE LEGAL SYSTEM: A LOOK AT

LEGAL EDUCATION \& TRAINING AND THE ROLE OF JUDGES

\section{Legal Education:}

As we have already observed, a civil law legal

education is offered at the undergraduate university. In common law societies, the path to earning a law degree is quite different. A law degree is earned in common law societies by attending a law school - an independent institute of higher education. A juris doctoris is a graduate degree which is earned after one is awarded an undergraduate degree at a four-year university. A legal education is treated not as a general education but as a professional education that prepares the student for legal practice. ${ }^{141}$

Upon entering law school, a student of the common law is typically instructed to read cases while paying close attention to the facts. ${ }^{142}$ Students are taught to examine the facts with a view to identifying the pertinent legal issues in the case. ${ }^{143}$ After discovering all of the legal issues, they are to determine what precedent was established in the case and finally, they 
are taught how to analyze it. ${ }^{144}$ This is the common law process of legal reasoning.

As one can see, legal reasoning in the common law is an inductive process. The law student begins with the specific facts to arrive at the general conclusion. ${ }^{145}$ The facts direct students and practitioners to the law which is most often found in law reports. Though the process has its own logic, it is not logical and rigid in the sense that the law is in the civil law world. The precedents do not necessarily follow from the facts; as stated earlier, one often finds conflicting precedents by courts dealing with analogous factual situations.

Students of the common law are taught to be pragmatic. They learn to ask, "What did we do last time?" when searching for the law on a given issue. The classroom is more interactive than in the civil law societies; there are typically fewer students in each class and professors generally expect each student to participate in class discussion. ${ }^{146}$

Since the common law is not considered a "law of scholars" and is more often viewed as a "law of lawyers", the professors and the lectures that they deliver are not 
valorized to the extent that they are in the civil law. Law in these societies is made by court decisions and, as many argue, lawyers. While many scholars are lawyers, their words are not perceived as creative of law as are the words of the judges or lawyers. Moreover, as was previously pointed out, professors most often teach the law by analyzing the work of legal practitioners and reading case decisions. It is less often that law school courses stress an academic orientation towards law. Because of the emphasis on the resolution of concrete, contemporary problems, the student with an acute ability for finding legal solutions to current conflicts is sure to succeed at law school. By acquiring the analytic skills essential to common law legal reasoning and applying them to concrete problems he or she is becoming prepared to practice law. That is precisely what a common law legal education aims to do educate students about the law and train them to practice it.

Role of the Judge:

One comparatist has remarked that the common law 
judge is "the oracle of the law."147 Another has referred to common law judges as somewhat of a "culture hero", even a "father figure". ${ }^{148}$ These phrases and comparisons indicate that the common law judge is an influential figure in the legal system.

Indeed the common law judge is often a well-known figure. She or he usually has had a successful career as an attorney and is regarded highly among her or his colleagues. ${ }^{149}$ Appointment to the bench varies from state to state, however the appointee is typically a highly competent and experienced legal practitioner. ${ }^{150}$ Once appointed to the bench, common law judges, particularly those in England, find themselves in an astonishing position in both the legal system and society. ${ }^{151}$ They enjoy a relatively high degree of independence from both the other limbs of the government and their fellow judges. ${ }^{152}$ The common law judges are encouraged to think for themselves and to deliver their own opinions, concurring or dissenting, in the event that they find the unsatisfactory the judgment delivered by the majority of the court. These separate and dissenting opinions are valuable because they have the potential, with the 
changes in society or in a court's composition, to become law in the future.

In a common law legal system law develops with court decisions; common law essentially means the law created and molded by judges. ${ }^{153}$ It is conceivable that what is law today may be replaced by a new law tomorrow. ${ }^{154}$ The role of common law judges is not only interpretive but creative. In common law countries like the United States where codes have been developed and a constitution is in place, the judges are often asked to interpret the written documents. However, what is often referred to as an interpretation of law becomes creative of law as judges decide what vague or ambiguous legislation means. ${ }^{155}$ Common law judges create the law by first, resolving a question that arises from a specific factual situation and second, making their decision binding on future cases with similar sets of facts. ${ }^{156}$

As statutes in common law states are typically narrow and directed towards simplistic matters, common law judges attach lower value to them. ${ }^{157}$ Precedents, on the other hand, represent the materials of argument and 
it is to them that lawyers and judges typically look to for law.

\section{ARE THE CIVIL LAW AND COMMON LAW TRADITIONS CONVERGING?}

I began this chapter with a quotation about the danger of taking one-sided views when comparing methods of legal thinking. One might argue that I failed to heed my own advice in the foregoing discussion of the two dominant legal traditions. However, as I stated in the introduction, the presentation of the traditions intended to highlight those features that are enduring and that make the traditions distinct from one another. As in any comparison of this kind, one must take into consideration that there are anomalies in each system and that transformations in society may affect transformations in the legal systems and ultimately the legal traditions. Thus there are few absolutes in either of the legal traditions.

Recently, a controversy has been sparked by those who contend that the civil law and common law legal traditions are not as divergent as was once believed. ${ }^{158}$ 
These individuals argue that the distinction made between the two traditions regarding the reliance on case law versus codes is no longer relevant. They cite an expansion of the function of judges in civil law societies as evidence for the convergence:

As legislators are becoming overtaxed by the novel problems in life and the civil and commercial codes on the Continent grow more out-dated, these countries are more and more turning to case-law to resolve disputes. ${ }^{159}$

On the other hand, common law states appear to be moving in the opposite direction. Zweigert and Kotz note that these states are increasingly looking to legislators to deal with questions that are obscured by case law. ${ }^{160}$ Garner observes that on the matter of the sources of law, common law and civil law societies "are not so diverse as may prima facie appear."161 Finally, Aldisert notices that the United States has borrowed from the civil law tradition the reliance on codes and statutes as sources of law. ${ }^{162}$

Craig Lawson argues that the similarities go even deeper than the case law/code distinction. He maintains that civil law and common law states both developed out 
of Western conception of law and hence share ideas about the place of law in the social order, the form of law, the application of law, and the substance of law. ${ }^{163}$ He points out that both the civil and common law traditions view minimum interference with individual freedom as the single greatest object of the rule of law. Individualism and liberty are cardinal principles of both common and civil law thought, hence the interests and needs of the free individual are favored over those of the larger group. ${ }^{164}$ Lawson further observes that law occupies a primary place in the social order in both legal traditions and applies equally to all persons regardless of their race, color, gender, ethnicity, etc. ${ }^{165}$

Finally, the two traditions share fundamental legal concepts including consent, obligation, rights, person, fact, exception, interest, and so on. ${ }^{166}$ Lawson's observations lead him to conclude that the two traditions, common law and civil law, should be thought of as related members of a larger western liberal democratic traditions. ${ }^{167}$ The common law and civil law legal traditions share important fundamental concepts and practices yet are distinct families within the larger 
tradition of Western legalism.

Merryman agrees that there are similarities between the common law and the civil law about the conception of law but believes that they have a more recent origin. ${ }^{168}$ He argues that developments in national and regional legal systems illustrate "a growing consensus about the law's proper extension within the society" and indicate "an increasingly common legal culture - a broader sharing of basic attitudes about the nature of law and the proper design and operation of the legal system."169 As he sees it, the interests of states have begun to converge and in this process, states have agreed that law is the proper mechanism for protecting or advancing those shared interests. As law becomes more universal, the differences between common law and civil law begin to fade.

Glendon points out that changes are occurring in the legal education of the two traditions as law schools and universities try to establish a better balance between theory and practice. ${ }^{170}$ She presents an argument in support of the claim that convergence in legal education will eventually affect convergence between legal 
traditions. ${ }^{171}$

While these observations would likely heighten one's doubts about the divergence of the common law and civil law traditions, it is equally important to point out that each of these scholars recognizes the enduring and significant differences between the two traditions. Merryman, for instance, sees the convergence of state interests and the common and civil law legal systems as threatened by an increasing divergence on the international scene between states with strong parochial interests. ${ }^{172}$ As law is an expression of its culture, the political divergence is ultimately reflected in the legal system. ${ }^{173}$

Aldisert recommends that his observation about the United States' increasing utilization of codes be considered in light of the fact that a conception of what a code is and the functions it should perform in the legal process are two different things in the United States and in France. ${ }^{174}$

Craig Lawson also states that an understanding of his argument for considering the legal traditions similar should take into account the lasting differences. He 
points out that the case analysis method in common law still receives much emphasis and that the civil law relies heavily on statutory interpretation. ${ }^{175}$ Additionally, the professional cultures of these two systems, particularly the role of the judges, remain distinct. ${ }^{176}$ In fact he contends that the role of the judiciary is the most distinguishing feature of these two legal traditions and that the stark difference I discussed above still remain. ${ }^{17}$ He also notes that legal reasoning and legal education in the two traditions remain significantly different. ${ }^{178}$

Zweigert and Kotz also warn students of comparative law not to overemphasize the apparent convergence between the dominant Western legal families. They argue that in civil law societies" "the processes of law, especially court decisions still cling to traditional styles and forms."179 Glendon, Gordon, and Osakwe agree with Lawson, Zweigert, and Kotz that significant differences between the two traditions remain more in the area of "mental processes, styles of argumentation, and in the organization and methodology of law than in positive legal norms." 180 
Lastly, Zweigert and Kotz contend that the question of whether or not the two traditions are converging on whether statute or judicial decision is the primary source of law isn't a very interesting one. ${ }^{181}$ The more important question is whether in arriving at a decision in a case, judges in common law societies and civil law societies use different methods of finding and applying law. ${ }^{182}$ Zweigert and Kotz seem to think that they do:

Given that the development of political ideas and institutions in Western Europe was quite different from that in England and that in consequence the standing of the judge, the role of the advocate, the methods of legal education, and the forms of procedure all differed widely, it will come as no surprise that the techniques of discovering and applying the law, indeed the typical methods of legal thought as a whole, have developed very differently. ${ }^{183}$

\section{IMPLICATIONS FOR INTERNATIONAL ILAW}

Very little has been written on how the common and civil law traditions view international law. Perhaps there is a reason for this. If it is the case that both the common law and civil law traditions are structured 
according to basic principles of western legal thought like freedom, individualism, rights and obligations, then we can expect that a judge on the World court educated under the civil law tradition and another judge on the World Court educated under the common law would possess a similar understanding of these ideals and their relation to the social order. This is not to say that the two judges would agree on the precise meaning of these terms when applied to a set of facts or that they would share similar attitudes toward these legal ideals. Rather it is to say, like the scholars above, that these judges would assume a similar social order, a similar role for law, and a similar set of legal norms. In short, they would approach an international legal dispute from the perspective of the Western legal tradition which emphasizes individualism, freedom from state intrusion, and the possession of rights and correlative duties. These expectations are further justified by the fact that international law is a creation of Western legal minds. International law is founded upon the same basic principles as common law and, even more so, civil law, and in this century the international legal 
structure has been developed by civil and common law legal scholars. One can observe the fundamental ideals of individualism and freedom that are central to those traditions given expression in international law through concepts like state sovereignty. Hence, if we accept the analysis of comparatists, international law most likely shares with the common and civil law traditions the enduring, fundamental similarities of all Western legal families and is most likely viewed by both common and civil law judges alike through the lens of western legal thought.

The divergence between the common and civil law traditions on the matter of legal education, legal reasoning, the role of the judge, and the sources of law would, on the other hand, appear to have consequences for international law. The comparatists agree that the Western legal framework is shared by common law and civil law students, however, they also agree that differences endure. Alice Erh-Soon Taj elucidates the differences between common and civil law that she finds significant to the internationalization of law. ${ }^{184}$ She avers that common law "recognizes the need to balance and weigh many 
factors in doing justice according to law: the law and principles of law, past discussions and decisions, moral sentiments and standards of behavior to be found in the relevant community, expectations and aversions that may reasonably be expected to govern the behavior of people at particular times and in particular circumstances, considerations of welfare and ability, of public policy and interest and more recently of social justice." 185 Civil law instead relies on open-ended concepts like "fair, reasonable, proper, sound, common-sensical and just." 186 Erh-Soon's analysis can be understood as implying that judicial decision at the level of international law would be very different depending on the legal tradition, common law or civil law, with which a dispute is approached.

It seems logical to suppose that the divergences identified by Erh-Soon and all the other comparatists would continue to be played out at the world Court, where justices of these differing traditions adjudicate disputes. Although international law does have a procedure and substance all its own, judges come to the Court with an education in the law and a history of 
approaching the law in a particular fashion. One can expect that these habits do not fade away once an individual has become an international judge. Indeed the absence of an international legal tradition that educates and trains its students like the common and civil law legal traditions necessitates recourse to those established traditions or whatever other approaches one might employ for reasoning through the legal dilemma. ${ }^{187}$ Moreover, the purpose of this project is to determine the effect of legal tradition on a judge's discovery and application of the law. Thus, the supposition made here is that legal tradition, particularly the legal education and the role of the judge within that tradition, matters to judicial decision in domestic law and therefore might matter to judicial decision in international law since the justices take to the world Court their own education and training.

The analysis of the decisions at the ICJ may not end the debate over whether the common law and civil law traditions are converging. However, it will focus on the methods used by the judges for applying and finding the law and through this process hopefully shed some light on 
the debate.

\section{THE SOCIAIIST LEGAL TRADITION}

\section{History}

The eighty year old socialist law tradition is young compared to its counterparts in other areas of the world. ${ }^{188}$ Although the Marxist philosophy upon which it is based originated a century earlier, it wasn't until the 1917 October Revolution in the former Soviet Union that a socialist legal tradition began to form. ${ }^{189}$ since that date, socialist law has been distributed to many other countries outside the former Soviet Union including China, Poland, Vietnam, Cuba, Mongolia, Albania, East Germany and Czechoslovakia. ${ }^{190}$

As stated in the first Chapter, socialist law is part of a larger Western legal tradition. Socialist law "exists within the family of civil law systems" but is infused with Marxist-Leninist ideology. ${ }^{191}$ This may seem surprising given that classical Marxists have traditionally had no use for the law and have viewed it as an instrument of exploitation. ${ }^{192}$ "Socialist legality" didn't come into force, however, until after a struggle, 
lasting from about 1917 through 1921, between, on the one hand, Soviet jurist E.B. Pashukanis and other classical Marxists who thought that law would wither away under Socialism, and on the other hand, those in the Communist Party, led by Andrei Vyshinsky, who wanted to use the rule of law to facilitate the Marxist path to Communism. With Stalin's official support, victory came to Vyshinsky and the others who wanted to build a socialist theory of law. Stalin too believed that the rule of law could facilitate the betterment of humankind and thus the Soviets' transition to Communist society. ${ }^{193}$ Hence, he followed the lead of other European leaders who had established western codes of law with the purpose of centralizing power. ${ }^{194}$ Because of his acceptance of Western legal thought and the promulgation of a constitution of 1936 in addition to a set of civil and criminal codes, scholars have referred to stalin as the "true father of modern soviet law."195 But this title may be somewhat misleading. Since he eventually used it as a tool for legitimizing and facilitating his infamous "reign of terror", Stalin's commitment to a western legal tradition and the rule of law appears disingenuous. 
The Soviet Union underwent momentous legal reform under its next leader, Nikita Kruschev. By the time of his death in 1964, the Soviet Union had codified a substantial amount of legislation, civil and criminal, and had replaced the facade of law created by Stalin with a rule of law created, implemented, and enforced by the Communist Party. ${ }^{196}$ The Soviet Union, then, from the late $1950^{\prime} \mathrm{s}$ to the mid $1960^{\prime} \mathrm{s}$, saw the development of a "Socialist legality" but with a methodology and infrastructure based on the civil law tradition. ${ }^{197}$

As in the civil law tradition, legislation was and continues to be the primary source of law. Judges under the socialist tradition enjoy even less independence than those in the civil law tradition and their teachings and writings are not considered law-making. ${ }^{198}$ The following Iist of secondary sources of law in the Socialist legal tradition indicates that civil law and socialist law are significantly different; they are uniquely socialist: acts of social organizations, acts of state abitrazh (networks of tribunals having exclusive jurisdiction over economic disputes between the state and other enterprises), acts of military commands, court judgments, 
and Marxist-Leninist doctrine.

The leadership of Leonid Breshnev contributed to the development of a Socialist legality rooted in civil law. Under his rule, the Constitution of 1977 was promulgated, many of the existing codes were modified, and new legislation was enacted. ${ }^{199}$

Further developments occurred under Mikhail Gorbachev. The structural transformations he initiated in the Soviet Union involved, among other things, empowering the Socialist legal system to assist in the implementation of the policies introduced by Perestroika. One scholar, writing in 1986, observed that "Today's Socialist legality, incessantly proclaimed as the means of modeling society and educating its citizenry, facilitates improvements in the legal system, legal profession, and legal education... the present soviet regime relies on law to legitimize and stabilize a very unrevolutionary, even conservative regime."200

Although the legal system appears to have been gradually given more legitimacy and power since 1917, traditionally the Communist party leaders have steered the course for both the state and socialist legality. In 
fact, the legal system in Socialist society must be understood as inseparable from the state. The Socialist conception of law demands that the legal system further the interests of the state.

\section{CONCEPTION OF THE LAW}

Again, Socialist law is founded upon the ideology of Marxism-Leninism. It begins with the assumption that legal relationships and forms of state have their roots in the material conditions of life. A rather lengthy quotation from Marx provides a succinct explanation of the essence of he and Engels' philosophy:

In the social production of their lives people enter into definite and necessary relationships which are independent of their will - production relationships, which correspond to the definite degree to which their material productive powers have developed. The totality of these production relationships constitutes the economic structure of society, the real basis upon which is built the juridical and political superstructure and to which definite forms of social consciousness correspond. The means of production of material life condition the social, political, and spiritual processes of Iife in general. "201

The writings of Andrei Vyshinsky provide further insight into the Marxist-Leninist conception of law, or 
perhaps more appropriately phrased "Socialist legality". He explains that law is one of the superstructures forming the society's economic structure and that law "depends on and is generated by production relationships." 202 In a capitalist society law expresses the will of those who dominate - the capitalists. It is one of the tools the bourgeoisie class employs in its effort to oppress and exploit the productive masses. "Law is merely the will of the dominant class, elevated into a statute. "203

Socialist law, however, serves an entirely different purpose. It "protects the interests of the toiling masses, who have been emancipated from exploitation and the weight of capitalism."204 Socialist law, then, cannot be understood apart from the Socialist state. According to Vyshinsky, "law draws its force and obtains its content from the state" ${ }^{205}$, thus the ends of Socialist law are the ends of the Socialist state as defined by the Communist Party:

* the elimination of exploitation and social inequality

* the distribution of resources in proportion to labor

* the guarantee to each individual full exercise of 
creative Eorces. ${ }^{206}$

Vyshinsky acknowledges Socialist legality's civil law roots. He points out that soviet law is made up of the Corpus Juris Romani - "the gospel of Capitalist society"but insists that it has been infused with "the revolutionary legal consciousness of the masses." 207

According to Socialists, the Socialist legal system is designed to fulfill its mission of total reorganization of society. ${ }^{208}$ It champions state ownership of land and of the dominant means of production and only grudgingly tolerates even the most minor instances of private ownership. ${ }^{209}$ It upholds national economic planning and absolute fidelity to Soviet leadership. ${ }^{210}$ Finally, it seeks to mobilize the citizens for a united movement towards the ideal society. ${ }^{211}$

This last goal illuminates the spiritual dimension of Socialist legality and of Marx's philosophy in general. Glendon, Gordon, and Osakwe refer to this aspect as "the theology of Socialist law." 212 Marxism is a spiritual ideology, "a philosophy whose basic task is the fundamental remaking of the conscience of the people."213 
stated in very simplistic terms, socialist legality is an all-encompassing ideology that seeks to replace the capitalist economic structure with, first, Socialism, and ultimately, Communism; law in a Socialist state has a facilitative function. But, as Zweigert and Kotz have observed, Socialist law also intends to be educational. Through consciousness-raising of the masses, the production relationships that exist under capitalism will be overthrown and supplanted with collective ownership of resources. Law operates to further the Socialist cause and it is intended to teach the transgressor how to live according to the principles of Socialism. The single guiding principle of Socialist law is Socialism and law's function is understandable only in light of Socialist ideolog்y .

INSTITUTIONAL ELEMENTS OF THE FORMAL LEGAL SYSTEM: A

LOOK AT LEGAI EDUCATION \& TRAINING AND THE ROLE OF JUDGES

\section{Legal Education:}

Immediately following the october Revolution, the Soviet system of legal education underwent massive 
changes. The first step made by the Communist Party was to, in 1918, open up university law faculties to all who applied. ${ }^{214}$ In 1919, the decision was made by Soviet authorities to send legal personnel to the European continent for education and training. ${ }^{215}$ As this was the era of "legal nihilism", the traditional institutions for legal education, known as university law faculties, were replaced with faculties of social science and an academic education was stressed over a legal one. ${ }^{216}$ Subsequently, law school enrollment dropped dramatically in the 1920's. When Vyshinsky's "Socialist legality" was officially approved by Stalin, legal study was reinstated and the university law faculties reopened. ${ }^{217}$ Since that time, though, enrollment at law schools has been kept at a minimum. Although socialist legality had been embraced by the Communist Party and is, at the present, increasingly becoming a significant dimension of Socialist rule, the Communist Party has consistently kept the number of lawyers in society at a minimum. ${ }^{218}$ Those individuals who have been given the opportunity to earn a law degree in the Soviet Union completed either a four year or five year program at a 
university law faculty. ${ }^{219}$ The courses the students are required to take are similar to, at least prima facie, those offered in the other traditions we have examined: legal and governmental theory, legal and governmental history, governmental law and Soviet structure, Administrative and Financial Law, International Law, Civil Law, Criminal Law and Criminology, The Civil Trial, The Criminal Trial, Penology, and Labor Law. ${ }^{220}$ Considering its origin in civil law, it is not surprising that a Socialist legal education is in many ways similar to a European one. A Socialist legal education is free, i.e. the state provides it at no cost to the student. ${ }^{221}$ As in civil law states, a legal education in the Soviet Union is non-professional and under exclusive control of the universities. ${ }^{222}$ Thus it emphasizes the theoretical over the practical, the abstract over the concrete. ${ }^{223}$

Substantive knowledge of codes of law and Socialist ideology is the primary focus of legal study in Socialist countries and very little emphasis, if any, is placed on the development of skills of critical analysis. ${ }^{224}$ Students are schooled in the philosophy underlying the 
law and are instructed in what the law is in particular areas and how to correctly apply it.

One's success in a Socialist law school is determined by one's proficiency for delivering oral presentations; the ability to write well is given little weight in the grading process. ${ }^{225}$ The planned shortage of lawyers in the former U.S.S.R. allows the state to guarantee every law school graduate a job as a jurist. ${ }^{226}$

Role of Judges:

Unlike their peers in the common law, judges in the socialist legal tradition are not an elite group of citizens. ${ }^{227}$ They receive low salaries and for years the Soviet Union did not require judges to have a legal education, hence their professional status has not been high. 228 Traditionally, judges in socialist legal systems have been accountable to the Party and have been required to uphold and advance its objectives. ${ }^{229}$ Consequently, judges in the socialist tradition have lacked the independence, status, and prestige that judges in common law systems enjoy. ${ }^{230}$

It has been observed that "the judiciary is truly 
the least dangerous branch of the Socialist government. "231 With the exception of Poland, most of the Socialist governments have modeled their judiciary after the soviet Union's. ${ }^{232}$ In Communist China, Hungary, Mongolia, and Cuba the primary role of judges is to apply predetermined law to a given case. ${ }^{233}$ Decisions are typically unanimous and the name of the author is almost always unknown. ${ }^{234}$ In the event that a judge dissents from the decision of a court and writes an opinion, it is common practice in Socialist countries for the dissenting opinion to go unpublished. ${ }^{235}$

Although the courts are directly accountable to the Party, it is the case that in some areas of law legislators have given judges freedom, within established parameters, to apply creativity. ${ }^{236}$ This appears to be more and more the case as legislatures have vested the Courts with the power "to facilitate development" of the Socialist person and "dispense justice" as it is understood in Socialist terms. ${ }^{237}$ Still, the overriding position in Socialist states is that legislation established by representative bodies should not be delimited by "judge-made law"..$^{238}$ And although courts in 
Socialist states have fostered the development of Socialist law, historically the true source of law has been the Party. ${ }^{239}$

Vyshinsky states clearly the responsibility of the Socialist jurist committed to the philosophy of MarxismLeninism:

[He] must expand his thinking beyond legal relationships and legal norms. He must reject this method in favor of dialectic materialism.. he must ponder relations of state/society, economic structure, production relationships.. the jurist cannot separate the science of public law from the science of economic development. ${ }^{240}$

\section{THE SOCIALIST PERSPECTIVE OF INTERNATIONAL L.AW}

The Socialists' view of international law is inseparable from their understanding of Western politics in general. International law is a tool employed by the bourgeoisie to facilitate their domination over the toiling masses. E.B. Pashukanis summed up succinctly the Socialist position on international law: "modern international law is the legal form of the struggle of the capitalist states among themselves for domination over the rest of the world. "241

James Hildebrand notes that the Soviets nonetheless 
admit that all states, including their own, use international law as a weapon. The only difference between the Socialist states and the Western states is that the former use international law to strengthen the "democratic principles of law and peace in international relations," while the latter uses it as a "means of deceiving the peoples, of concealing imperialist designs of expansion and aggression. "242

Hildebrand offers an excellent analysis of the relationship between Socialist law and international law. He notes that the Socialist view of society creates a dilemma for soviets in the realm of international law. He argues that Socialists, in an effort to be part of an international community, have had to decide whether to create an international legal system all their own or to collaborate with the Western powers regardless of their fundamentally irreconcilable socio-political outlooks. ${ }^{243}$ According to Hildebrand, the history of Socialist legal thought with regard to international law has involved a series of attempts to reconcile traditional international law with Marxist-Leninist doctrine. ${ }^{244}$

Hildebrand and others suggest that it was the 
writings of one Soviet legal theorist in particular, Grigori I. Tunkin, which brought the Socialists closer to a reconciliation of international law and Marxism. ${ }^{245}$ In 1956, Tunkin conceded that international law would have to represent, to at least a certain extent, a compromise between socialist and capitalist states desirous of a body of rules applicable to all states. If international law were to embody only socialist principles or only capitalist principles then the states with differing ideologies would be unable to agree on universal rules for state behavior. Despite these concessions, Tunkin nonetheless remained firm on the notion of soviet supremacy in international law and credited his home state with guiding the course of international law. ${ }^{246}$ At roughly the same point in time that Tunkin was contributing his ideas on Socialist legal theory, the great Socialist states, China and the U.S.S.R., agreed to adhere to five principles in their international legal relations with capitalist states:

1. the principle of the maintenance of mutual respect for the territorial integrity and sovereignty of other 


\section{states ;}

2. the mutual obligation not to attack other states;

3. the mutual obligation of non-intervention in the internal affairs of other states;

4. mutual equality and the granting of equal advantages;

5. peaceful coexistence. ${ }^{247}$

In more recent years, cooperation has replaced coexistence as the most important element in the international legal relationship between the soviets and the Western states. ${ }^{248}$ The "new thinking" that was introduced into Soviet Society in the mid to late 1980's in the form of Perestroika and Glasnost and which fueled the break-up of the U.S.S.R. has helped to engender a less antagonistic relationship, at least legally speaking, between the Soviets and the developed Western states. Still, one would expect differences to remain. Surely, as long as the Socialist and capitalist states have fundamental political disagreements, these will be reflected in international law. However, I would argue that even if these political disagreements vanished tomorrow, the legacy of Socialist legal education and 
training would remain at the World Court for some time. Although Hildebrand noticed as early as 1969 a warming of the relationship between the Soviet Union and the Western states, those Soviets in positions of power in international law today were educated and trained under a strongly Socialist state. ${ }^{249}$ Even though dramatic changes have occurred in the U.S.S.R. in the past decade or so, those transformations do not erase the Socialist past and in fact, those transformations remain in a state of instability. So, the fact that the soviets and the Western states have warmed up to one another in the international legal arena does not eradicate the possibility that a Socialist legal education determines the way in which a judge on the court discovers and applies international law. Indeed, it might be the case that it is precisely this socialist legal education and training that divides Socialist judges from their western counterparts in those cases that they disagree. Since it will take at the very least another twenty years until the newest generation in the U.S.S.R. could become influential in international law, it ought to be expected that if Socialist legality were to fade out of the 
international legal scene, it would not be for many years to come.

From the discussion of the Socialist legal system above, one would expect to find substantive and procedural divergences between Socialist judges at the ICJ and their counterparts educated under other legal traditions. If Socialist thought structures Socialist legality and is as all-encompassing as legal scholars like Vyshinsky and Tunkin argued it was, then one would expect the decisions of Socialist judges at the ICJ to reflect elements of Socialist, or Marxist-Leninist thought. This is made even more true by the fact that judges educated under a Socialist legal tradition were taught to be a servant of the Socialist state and to unquestioningly enforce its laws. Of course the judges at the World Court are not instructed to enforce or apply Socialist law or to follow the dictates of a Communist Party. However, one would likely infer from the teachings of the legal scholars noted above that the Socialist judge is supposed to represent Socialist principles at an international forum. The judge's commitment to Socialist ideals may have relaxed a bit 
with the transition from coexistence to cooperation, but one would not want to suppose that cooperation on the part of the Soviets means acceptance of capitalist principles and practices.

One's expectations of finding elements of MarxistLeninist thought may contradict, however, the expectation that Socialist judges will not deliver lengthy written opinions or that they will not deliver separate opinions at all. The emphasis in Socialist legal education on oral over written presentation makes an analysis of a written decision by a Socialist judge potentially problematic. An examination of a judgment for MarxistLeninist thought is not made easy by a short written judgment or no opinion at all.

On the other hand, one should not be surprised to find at the World Court a history of Socialist judges dissenting without a written opinion since the opinion of the judges in Socialist legal systems is not highly valued. Still, on the other hand, one might not be surprised by a Socialist judge who never dissents since dissenting opinions are highly discouraged in socialist legality. 
Since these expectations are clearly contradictory, I would like to emphasize that the focus of this study is international law, not domestic law. With this and the Socialist position on international law in mind, I would think it more likely that Socialist judges at the World Court would dissent from the judgment submitted by the majority of justices than acquiesce simply because that is what they were educated to do. The Socialist judge plays a role at the world Court that is entirely different than the role she or he would play in the judiciary of her or his native state; the requirements of the role of representing the Party are very different at home than in international legal relations. A judge operating within the socialist state upholds the law created by the Party by behaving as a diligent servant of the Party. A Socialist judge at the world Court is not dealing with law created by the Party and thus, to be a diligent servant of the Party may have to dissent from the majority who might represent western powers.

One should not expect, however, that a dissenting Socialist judge at the World Court will deliver an opinion amounting to a lengthy treatise on Marxism- 
Leninism. The legal tradition under which these individuals have been bred taught them habits and methods that should be reflected in their decision-making at the World Court. Further, with the cooperation that has been witnessed in the international legal relations between the Soviet Union and the West one would expect to see a degree of ideological tolerance evolving between these judges. 


\section{CHAPTER THREE}

\section{The International Court of Justice}

The ICJ has rendered decisions in over 76 international disputes since its inception in $1946 .{ }^{250}$ This project looks at three of these cases and analyzes them with a view to discovering whether the legal tradition under which a justice is educated and trained for a career in the legal profession determines how she or he finds and applies the law when adjudging an international dispute at the World Court. The limitations of space and time preclude a full-scale investigation into each and every decision made by the Court throughout its entire history. Instead, a determination may be made through an examination of a smaller set of cases chosen on the basis of clearly defined criteria. ${ }^{251}$

The three disputes selected for analysis were chosen because they each satisfied certain criteria. First, each case was decided during a period of the ICJ's activity that is distinguishable from the next. Scott, Bothwell, and Pennell examined the history of the Court's activity and found, based on the political and legal 
developments since its inception, that the ICJ's history could be logically divided into three eras: ICJ I (1946 through 1962), ICJ II (1963 through 1985), and ICJ III (1986 to present). ${ }^{252}$

Scott et al. argue that ICJ I can be understood as a period of legal idealism. ${ }^{253}$ with the recent memory of two world wars firmly in their minds, state leaders turned to international law for a peaceful settlement of their disputes. ${ }^{254}$ ICJ I represents one of the busiest schedules in the Court's history; from 1946 to 1962 thirty one contentious cases and 12 advisory opinions were submitted to the court. ${ }^{255}$

The period known as ICJ II marked a significant decline in the number of cases submitted to the court. ${ }^{256}$ From 1963 to 1985, the Court received only 12 submissions of contentious cases and 6 submissions for advisory opinion. ${ }^{257}$ Scott et al. further point out that several of the judgments delivered by the court during these years were outrightly defied. ${ }^{258}$ They explain this period of inactivity at the court as the result of the intensification of cold war hostilities, including the October 1962 Cuban Missile Crisis. ${ }^{259}$ 
Like ICJ I, ICJ III represents a period of "post-war legal euphoria."260 As the cold war has come to an end, the ICJ is experiencing another round of high activity. It appears that once again states are perceiving their disputes as ones that would be best solved through the application of legal rules and principles.

The cases I chose satisfied a second criterion: division. Divisive judgments appear to provide excellent case studies for reaching conclusions about judicial decision-making by individual justices at the World Court. Because they typically generate individual opinions, both dissents and concurring opinions, they also tend to provide further insight into the legal reasoning of individual justices. On the other hand, cases with a majority judgment representing nearly every justice on the court tell us comparatively less about the way each judge found and applied the law in a given case. To be sure, a judgment supported by the entire court may be indicative of a uniform method of finding and applying the law in a particular case. Nonetheless, the history of the Court demonstrates that it has been split on more occasions than it has been in full agreement, and thus 
warrants an examination into potentially divergent approaches to judicial decision at the World Court.

More importantly, however, divisive judgments represent those cases that most likely diverge on lines of legal tradition. Because the judges come to the Court with very different backgrounds and legal experience, a one-sided judgment most likely indicates that legal tradition did not determine how the justices found and applied the law. The cases I have chosen are widely split with, in some cases, the majority of the Court filing separate opinions, declarations or dissents in opposition to the Court's judgment or the way in which it arrived at the judgment.

I have also chosen to omit from the following examination the decisions and votes of the ad hoc judges in these cases. Although the votes of these individuals carry equal weight in the cases and are often accompanied by individual opinions, research indicates that ad hoc judges almost always vote in favor of the state that appointed them. ${ }^{261}$ In one study, Il Ro Suh found that from 1922-1967 ad hoc judges voted with the government that appointed them in $91 \%$ of the decisions. ${ }^{262}$ Thomas 
Hensley found, in another study, that ad hoc judges deviated from the other justices on the court $44 \%$ of the time, showing a marked voting preference for the countries selecting them. This evidence should not be surprising, as ad hoc judges are appointed to the Court for one case by a state who is a party to that case.

ICJ I: The Case Concerning Right of Passage Over Indian Territory, Judgment (12 April 1960) ${ }^{263}$

\section{Facts and Arguments:}

On December 22, 1955 the state of Portugal filed an application with the ICJ requesting that the Court uphold a Portuguese right of passage through Indian territory. ${ }^{264}$ Portugal maintained that its sovereignty over three enclaves in the Indian Peninsula, Goa, Daman and Diu, was violated in July, 1954 when Indian authorities prevented Portugal from passing through Indian territory to the enclaves. ${ }^{265}$

In its application Portugal explained that prior to July, 1954 the Indian and British practice was to, allow the Portuguese to pass through Indian territory with the purpose of exercising Portuguese rights of sovereignty 
over the enclaves. The Application alleged that since 1950 the situation had changed and that the Government of India had denied a right of passage in July of 1954 pursuant with the "an open campaign" it was waging for the annexation of Portuguese territories, specifically the enclaves located within Indian territory. ${ }^{266}$ It further alleged that the Indian government had initiated and supported a violent uprising on the enclaves that begun prior to July of 1954 and that by denying Portugal passage the Indian government was effectively preventing the Portuguese government from putting a stop to the violence. ${ }^{267}$

Portugal insisted that India's refusal to allow Portugal the right of passage in July of 1954 was in violation of international law and part of a larger effort on the part of India to expropriate the enclaves that belonged to the state of Portugal. Counsel for Portugal cited the following sources of law as supportive of the state's position: 1) The Treaty of Poona concluded between Portugal and the Marathas in 1779 transferring sovereignty of the enclaves to Portugal; 2) local custom and general custom; and 3) concordance of 
municipal legal systems with respect to access to enclaved land. ${ }^{268}$ Portugal further argued that state practice and opinio juris supported its alleged right of transit. ${ }^{269}$

India invoked the reservations it had attached to its acceptance of compulsory jurisdiction of the Court. In its fifth preliminary objection, the government of India denied that the ICJ possessed jurisdiction over the case, insisting that the dispute involved Indian territory and thus fell under India's jurisdiction. ${ }^{270}$ In a sixth preliminary objection, it further opposed the Court's jurisdiction, but on the grounds that the situation began prior to February 5, 1930, the date set by India in its acceptance of the Optional Clause stipulating that no dispute arising earlier than it could be adjudicated by the Court. ${ }^{271}$

On the merits, India maintained that a right of passage could not be recognized generally; states reserve the right to limit the right of passage if the situation calls for it. A right of passage is both indeterminate and indeterminable - it finds no basis in principles of international law or in custom, local or general. ${ }^{272}$ 
Counsel for India further argued that the treaty Portugal relied on for its case was not a treaty at all but rather a set of negotiations that never resulted in an agreement. ${ }^{273}$ India held that there was never any official transfer of sovereignty of the enclaves in question to the state of Portugal; if the Portuguese usurped sovereignty of the enclaves, the Indians reasoned, the right of passage surely did not come with this title of sovereignty. ${ }^{274}$ India also pointed to governmental acts of both Great Britain and India between 1818 and 1954 as proof of a denial on their part of a Portuguese right of passage. ${ }^{275}$

Finally, in defense of its denial of passage to Portugal on July 1954, India described the violent uprising in the enclaves as a liberation movement by Asians who desired to join the Union of Independent India. ${ }^{276}$ India denied the accusation that it was assisting the overthrow of Portuguese power in the enclaves and argued that at the time of the request for and subsequent denial of passage to Portugal, any Portuguese presence in the enclaves would have escalated the violent conflict. ${ }^{277}$ 


\section{Judgment:}

The issue at the heart of the Right of Passage case is one that concerns all states: territorial sovereignty. The Court in the Right of Passage Case was charged with determining the limits and/or extent of state sovereignty with regard to a right of passage. A right of passage threatens a state which must cede it to other states because it represents a limitation to the authority that that state may assert over territory its government rightfully claims as its own.

The overriding issue of sovereignty is evidenced in the questions upon which the court voted. The following is a breakdown of those votes:

1) 13 to 2 - The Court rejected India's fifth preliminary objection wherein the Indian government argued that the question of the grant or refusal of the passage claimed over Indian territory by Portugal fell exclusively within the domestic jurisdiction of India and outside the jurisdiction of the court; 
2) 11 to 4 - The Court rejected India's sixth preliminary objection wherein the Indian government argued that the dispute arose before 5 February 1930;

3) 11 to 4 - The Court found that Portugal did have in Indian territory between the enclaves of Dadra and NagarAveli and the coastal 1954 a right of passage over intervening district of Daman and between those enclaves, to the extent necessary for the exercise of Portuguese sovereignty over the enclaves and subject to the regulation and control of India, in respect of private persons, civil officials and goods in general;

4) 8 to 7 - It found that Portugal did not have in 1954 such a right of passage in respect of armed forces, armed police, and arms and ammunition;

5) 9 to 6 - The Court found that India had not failed in 1954 to fulfill its obligation in regard to that right of passage $i^{278}$ 
Majority $=M$
Dissent $=D$

Separate Opinion $=$ so

JUDGES-TRADITION
\begin{tabular}{|l|c|c|c|c|c|}
\hline Klaestad - civil & $\mathbf{1}$ & $\mathbf{2}$ & $\mathbf{3}$ & $\mathbf{4}$ & $\mathbf{5}$ \\
\hline Zaf. Khan - common & $\mathrm{M}$ & $\mathrm{M}$ & $\mathrm{M}$ & $\mathrm{M}$ & $\mathrm{M}$ \\
\hline Basdevant - civil & $\mathrm{M}$ & $\mathrm{M}$ & $\mathrm{M}$ & $\mathrm{M}$ & $\mathrm{M}$ \\
\hline Hackworth - common & $\mathrm{M}$ & $\mathrm{M}$ & $\mathrm{M}$ & $\mathrm{M}$ & $\mathrm{M}$ \\
\hline Winiarski - civ/soc & $\mathrm{M}$ & $\mathrm{D}$ & $\mathrm{D}$ & $\mathrm{M}$ & $\mathrm{M}$ \\
\hline Badawi - civil & $\mathrm{M}$ & $\mathrm{D}$ & $\mathrm{D}$ & $\mathrm{D}$ & $\mathrm{D}$ \\
\hline Spender - common & $\mathrm{M}$ & $\mathrm{M}$ & $\mathrm{M}$ & $\mathrm{D}$ & $\mathrm{D}$ \\
\hline Armond-Ugon - civil & $\mathrm{M}$ & $\mathrm{M}$ & $\mathrm{M}$ & $\mathrm{D}$ & $\mathrm{D}$ \\
\hline Kojevnikov- social & $\mathrm{D}$ & $\mathrm{D}$ & $\mathrm{D}$ & $\mathrm{M}$ & $\mathrm{M}$ \\
\hline Quintana - civil & $\mathrm{M}$ & $\mathrm{M}$ & $\mathrm{D}$ & $\mathrm{M}$ & $\mathrm{M}$ \\
\hline Cordova - civil & $\mathrm{M}$ & $\mathrm{M}$ & $\mathrm{M}$ & $\mathrm{M}$ & $\mathrm{M}$ \\
\hline Koo-common & $\mathrm{M}$ & $\mathrm{M}$ & $\mathrm{M}$ & $\mathrm{D}$ & $\mathrm{D}$ \\
\hline Spiropoulos - civil & $\mathrm{M}$ & $\mathrm{M}$ & $\mathrm{M}$ & $\mathrm{D}$ & $\mathrm{D}$ \\
\hline
\end{tabular}

By a vote of 13 to 2 the Court rejected India's fifth

preliminary objection. The Court observed that Portugal

had invoked international law to support its position and it agreed with the Portuguese that the dispute was on an international plane. ${ }^{279}$ It also struck down India's sixth preliminary objection which precluded a state from

bringing to the Court a dispute which originated prior to 5 February 1930. The court found the law relevant to this objection in the PCIJ's decision in the case of the Electricity Company of Sofia and Bulgaria. ${ }^{280}$ In that case the Court ruled that the prior situation or facts of a dispute which are to be considered in adjudicating that 
dispute are only those which are the source of the dispute not the source of the right in question in the dispute. ${ }^{281}$

On the merits, the Court upheld India's argument that the Treaty of Poona did not grant sovereignty of the enclaves to Portugal and that rather what was established was a revenue tenure. ${ }^{282}$ By granting permission of transit to the Portuguese to collect revenue in the villages the Indian and British governments had not established a Portuguese right of passage.

On the matter of customary international law, however, the Court did accept Portugal's argument that because the British and Indian governments never objected to the Portuguese representing themselves as sovereign of the enclaves, those governments tacitly recognized Portugal as sovereign over the village. According to the Court, past practice demonstrated that the passage by the Portuguese of private persons, civil officials, and goods into the enclaves went unhindered, with the exception of blockages during World War II. ${ }^{283}$ The Court observed that for one and one quarter century, the constant and uniform practice of allowing free passage between Daman and the 
enclaves for transporting private persons, civil officials and goods endured and thus developed into a law between the Parties with the establishment of a right for Portugal and a correlative obligation for India. ${ }^{284}$

The situation was different, however, for passage of armed forces, armed police, and arms and ammunition. The Court found no evidence supporting Portugal's claim that all transit was exercised or permitted and in fact it cited evidence that demonstrated that previous authorization was required to send armed forces, etc. through British and then Indian territory. ${ }^{285}$ In short, the court found a right of transit and a correlative obligation with regard to the passage of civil and private persons and goods but neither a right nor an obligation pertaining to the passage of armed forces, armed police, arms, and ammunition.

\section{Composition of the Court: ${ }^{286}$}

Helge Klaestad (Norway): Judge Klaestad earned his Doctor Juris at the University in Oslo, a civil law institution. Shortly thereafter he embarked on a career in international arbitration. He presided over the AngloGerman Mixed Arbitral Tribunal in London and in the 
following year he became the Sole Arbitrator of a number of bilateral treaties. After many more similar appointments, Judge Klaestad was finally appointed to the Supreme Court of Norway in 1931 and fifteen years later he became a justice at the ICJ. Judge klaestad served on the ICJ from 1946 to 1961.

Muhammad Zafrulla Khan, (Pakistan): Judge Zafrulla Khan was educated under the common law tradition as he received his Bachelor of Arts from Punjab University and a Bachelor of Laws from King's College in London. He has held many prestigious appointments including President of the General Assembly of the United Nations, member of the Supreme Court of India and first Minister for Foreign Affairs of the newly created Republic of Pakistan. Judge Zafrulla Khan served on the ICJ from 1954 to 1961 and again from 1964 to 1973.

Jules Basdevant, (France): Judge Basdevant earned his Doctor of Law in Legal, Political and Economic Sciences in a civil law institution on the European continent. He was a professor of law at Rennes, Grenoble and Paris and 
at the Naval Staff College, the Centre of Higher Naval Studies, and at the Academy of International Law at The Hague. Judge Basdevant was a member of the French delegation at many international conferences, an agent of the French government in many international arbitrations, and legal advisor to the French Foreign Ministry. He served on the ICJ from 1946 to 1964 .

Green H. Hackworth, (U.S.A.): Educated at Valparaiso, Georgetown University, George Washington University and the University of Kentucky, Judge Hackworth was a student of the common law tradition. For twenty years he worked in the state Department serving as an attorney, a solicitor, and as legal advisor to the secretary of state. He sat on the Supreme Court of the District of Columbia and represented the United states at numerous international legal conferences. Judge Hackworth served on the ICJ from 1946 to 1961.

Bohdan stefan Winiarski, (Poland): Judge Winiarski was educated in the law at Warsaw, Cracow, Heidelberg and Paris, all civil law universities at the time of his 
education. Early on in his tenure at the ICJ, however, the October revolution brought Socialist thought to the Soviet Union and to its Eastern European satellites, including Poland. His teaching position in Cracow was interrupted in 1917 when he was enlisted in the Russian Army. He eventually returned to teach law in Poland and serve as a diplomat for his country. Judge Winiarski served on the ICJ from 1946 to 1967.

Abdal-Hamid Badawi, (Egypt): Judge Badawi received his Doctor of Law from the University of Grenoble, a civil law institution. In Egypt he was a Professor of law, a Director in the Ministry of Justice, and Legal Adviser to the government. He also served as Minister of Finance, Minister for Foreign Affairs, and Senator. Like many of his counterparts on the ICJ, he was a delegate for his country at many international conferences. Judge Badawi served on the ICJ from 1946 to 1965.

Sir Percy Spender, (Australia): Judge Spender received a common law legal education at Sydney University in Australia. His interests led him to a career in public 
service in both domestic and international roles. He was a member of the House of Representatives, Treasurer, Minister for External Affairs, and Ambassador to the United States. He led many Australian delegations to international conferences and was Vice-President of the 5 th General Assembly of the U.N. Judge Spender served on the ICJ from 1958 to 1967.

Enrique C. Armand-Jgon, (Uruguay): Although no clear information exists, it appears that Judge Armand-Ugon received his Doctor in Law and Social Sciences in Uruguay, a civil law state. There he worked as a Provincial Attorney, a Judge of the Court of First Instance, a Judge in the Court of Appeal, a Judge in the High Court, and he finally served as President of the High Court. Like his counterparts on the World Court, he was represented his country at many international conferences. Judge Armand-Ugon served on the ICJ from 1952 to 1961.

Feodor Ivanovich Kojevnikov, (U.S.S.R.): Judge Kojevnikov studied socialist law at Moscow University in the 1920's. 
He became a professor upon graduation and twice served as Dean of his Faculty. Kojevnikov held several appointments with the soviet government including President of the Legal Section of the Society for Cultural Relations of the USSR with Foreign Countries and Member of the Committee of Experts in Legal Science at the Ministry of Culture of the USSR. Judge Kojevnikov served on the ICJ from 1953 to 1961.

\section{Lucio Manuel Moreno Quintana, (Argentina): Judge Moreno} Quintana earned a Doctor of Law at Buenos Aires, a civil law institution, in 1920. For most of his life he worked as a university professor in Buenos Aires however his success took him to lectures all over the world. He held the directorship of the International Law Institute in Buenos Aires and in addition to teaching, held public offices. Judge Moreno Quintana served on the ICJ from 1955 to 1964 .

Roberto Cordova, (Mexico): Judge Cordova also studied law under the civil law tradition, at the National University of Mexico. Throughout most of his career 
prior to becoming a judge at the ICJ he served as a diplomat for Mexico. He was a delegate to numerous international conferences and was appointed Legal Advisor to the Mexican Foreign Service. Judge Cordova served on the ICJ from 1955 to 1964.

v.k. Wellington Koo, (China): Judge Wellington Koo was educated in the common law in America at Columbia University. He became a government official upon his return to China and from 1915 to 1920 he served as Minister to Mexico, Cuba and the USA. He represented China at the League of Nations and from 1926-1927 was both Prime Minister and Foreign Minister of China. Judge Wellington Koo served on the ICJ from 1957 to 1967.

Jean Spiropoulos, (Greece): Judge Spiropoulos was educated in the civil law on the European continent and earned his Doctor of Law in Leipzig in 1922. In Greece he became a Professor of International Law at Salonika and Director of the Legal Department of the Ministry of Foreign Affairs. He then turned to the international sphere where he held, among other positions, the 
chairmanship of the International Law Commission. He was a delegate for Greece at several international conferences and served as judge ad hoc in the Ambatielos case. Judge Spiropoulos served on the ICJ from 19581967 .

\section{Analysis:}

From the distribution of votes presented in the table above, one is led to conclude that, at least in the case of the justices who comprised the majority and were educated under either a common law or civil law system, legal tradition was not a variable in the judicial decision-making process. An analysis of the decision confirms this observation.

In its effort to find the law, the court concerned itself primarily with the practice that had evolved between the two states. Indeed it explicitly found the law governing this dispute in one and one quarter century's worth of state practice between Portugal, on the one hand, and India and Great Britain on the other. The law applicable to this matter was a product of the interactions of these particular states: 
The Court is here dealing with a concrete case having special features. Historically the case goes back to a period when, and relates to a region in which, the relations between neighbouring states were not regulated by precisely formulated rules but were governed largely by practice. Where therefore the court finds a practice clearly established between the two States which was accepted by the Parties as governing the relations between them, the court must attribute decisive effect to that practice for the purpose of determining their specific rights and obligations. Such a particular practice must prevail over any general rules. ${ }^{287}$

Taking into consideration that state practice and opinio juris are fundamental sources of customary international law, the judgment may not be surprising. ${ }^{288}$ Nonetheless, the Court's emphasis on the history of the relations of the two states, i.e. the facts, and the understandings the governments had about these relations, is reflective of the common law style of reasoning. One sees in an examination of the decision that the court spent little time dwelling on the principle of territorial sovereignty at issue in the case and in fact searched for the limits and/or extent of sovereignty through its examination of the facts and of the understandings each state displayed about Portugal's passage through Indian territory. 
This common law style of reasoning is countered by the Court's application of the law which is more representative of a civil law approach to adjudication. The justices who comprised the majority limited their function to an application of the law found through a knowledge of the facts. They did not set out to create law or impose judge-made law on Portugal and India. Instead, they applied the law that they perceived to have been created by the two states in conflict over the course of history.

Thus the Court's method of finding and applying the law was not representative of one legal tradition nor was the judgment a product of only or mostly civil law judges or only or mostly common law judges; the judgment embodied methods of judicial reasoning and decision that could be traced back to both the common and civil law traditions.

Thus we may want to interpret the decision of the court in The Right of Passage Case as more reflective of international law and the rules it establishes for the justices than of a particular type of legal tradition that dominated the court at that time. If customary 
international law, a primary source of international law, is the law governing this dispute, then an examination of the facts is the requisite method for discovering the law. If it is customary international law that is being determined, the Court would want to determine what the state practice relevant to the dispute was between the two states and whether or not the additional component of opinio juris had been developed. Further, if the Court perceived its function in the same way as states perceived it, then it would assist the states in determining what law they had created rather than creating law itself.

The dissenting opinions do, however, raise the possibility that legal tradition may have been a variable in at least one decision. Like the majority, the dissenters are an eclectic group. Aside from the two ad hoc judges, they are composed of three civil law judges, one common law judge, one judge educated in the common law and Asian law, one Socialist judge, and one judge educated in the civil law and practiced in Socialist law. Justice Moreno Quintana, a civil law judge, began his process of legal reasoning with an explication of the 
principle of state territorial sovereignty which he viewed as placing a burden on Portugal to prove why India had an obligation to honor a right a passage. ${ }^{289} \mathrm{He}$ averred that a right of passage is neither varying nor inexact; "The right either exists in law or it does not." 290 He further refused to consider the claim of sovereignty based on practice as he saw that the Court had done in its judgment. Before turning to an analysis of the facts, Moreno Quintana explained how he would judge their significance in the dispute:

In the international sphere the normal method of acquiring rights or of contracting obligations takes the form of an agreement, which in its widest sense is termed a treaty... In any case, I consider that the validity of a general principle may take the place of international custom, and the existence of international custom the place of a treaty. ${ }^{291}$

It appears, from this brief analysis, that Moreno Quintana's entire judgment hinged on what he believed should have been done in principle as he concludes it with a statement about how the Court's support of the Portuguese claims to sovereignty over the islands equates to support of the survival of the colonial system. To uphold Portugal's claim to a right of passage with regard 
to civilians and goods is to "fly in the face of the United Nations Charter. ${ }^{292}$ He warned the Court that it, as the judge of its own law and the judge of its own age, "cannot turn its back upon the world as it is. International law must adapt itself to political necessities. " 293

Moreno Quintana appears to be searching for an answer to the fundamental question underlying the civil law tradition: "What is just?" His single-minded concern with principle is representative of the reasoning taught to students of the civil law. However, if his method for discovering the law looks more reflective of the civil law tradition, then his admonition to the court betrays a common law perception of the judge as a powerful individual with the authority and duty to create law as she or he sees fit. He implores the Court to take a stand against imperialism through its judicial capacity, in essence asking the court to make a political statement rather than a legal one. He is, in this sense, the quintessential common law judge exercising the power to make grand statements about the morality of the law. These observations notwithstanding, the substance of 
Moreno Quintana's concerns can lead one to a different conclusion about why he discovered and applied the law the way that he did. Recall that Moreno Quintana is a judge from Latin America, specifically Argentina. With this in mind, his decision may look more like a political statement than a legal one. It is no secret that many Latin American governments and those of other relatively less developed states have been and continue to be dissatisfied with what they perceive to be a domination of global resources by more developed and consequently, more powerful states. ${ }^{294}$ These governments often criticize the institution of colonization of smaller, less developed regions by larger, more powerful states as exploitative relationships designed to keep the power imbalance in place. ${ }^{295}$ Thus, Moreno Quintana's admonition could have been, and in light of the observations made about the influence of legal tradition on the majority and on Moreno Quintana, may have more likely been politically motivated. If Moreno Quintana's discovery and application of the law exemplifies elements of both the common law and civil law traditions, and perhaps too the Socialist law tradition with its disdain for Western 
imperialism, then it seems that the probability that the legal tradition under which he was educated and worked most of his life, the civil law, is slim. This being the case, it would seem that the alternative explanation, based on political convictions, is the more powerful one. This finding further strengthens the conclusion made about the judgment.

Armand-Ugon and Badawi were the only other dissenters whose methods for discovering and applying the law may be attributable to a civil law education. Badawi expressed concern over the difficulty of reconciling recognition of sovereignty with the exercise of a discretion which, in principle, repudiates one essential consequence of that sovereignty. ${ }^{296}$ Still, he indicated that the answer to this question could only be found through a thorough analysis of the facts. He did, however, mention that the confusion surrounding some of the facts may have obscured the "true legal aspect" of the relations between Portugal and Great Britain, and then India - an indication that truth is somewhere lurking behind the confusion of the facts. ${ }^{297}$ Armand-Ugon also demonstrated a slight interest in 
finding the "right" answer; he expressed concern with the right of territorial sovereignty and the demands that it made upon the states and the Court. Before presenting his argument, Armand-Ugon advised his fellow judges:

Our reasoning must proceed on the basis of the validity of the argument in favour of full sovereignty and of that in favour of a saranjam... It would be inadmissible to grant sovereignty over certain territories or a saranjam of certain villages and then to set up obstacles to the fulfillment of the obligations agreed upon. ${ }^{298}$

Both Armand-Ugon and Badawi then reasoned, albeit to varying degrees, with a governing principle in mind.

The rest of the justices who dissented from at least one question on the merits concentrated exclusively on the facts of the case and on what law could be found in the history of the dispute. Judge Spender, who disagreed with the Court's distinction between the passage of armed forces, etc. and civilian goods and persons and its conclusion that India had not acted contrary to its obligation, appears to have placed concerns of principle in his argument as a second premise. He began his argument with an analysis of the meaning of the Treaty of Poona and proceeded to examine the historical record on 
Portuguese passage to the enclaves, citing dates and British and Indian responses to requests for passage. ${ }^{299}$ Only after the discussion of facts did spender touch upon some of the principles governing the dispute. He stated that "a necessity to apply for a license before an act is done is not necessarily incompatible with a right to do that act." ${ }^{300}$ He further asserted that "discretion in refusing and granting permission is not absolute - it is controllable and must be exercised in good faith. "301 This type of argument is also on display in Wellington Koo's separate opinion. Like Spender, he objected to that part of the Court's decision that takes armed forces, armed police, and arms and ammunition out of the scope of the right of passage. ${ }^{302}$ And again, like Spender, Wellington Koo paid close attention to the facts of the case, including documents such as agreements, notes, and treaties. He cited dates and recorded the responses of Britain and India to Portuguese requests for transit to the enclaves.

Again, only after he established the factual situation and found that there developed a practice of allowing all types of goods and persons to pass to the 
enclaves did Wellington Koo make recourse to principles of international law or ideas about state behavior. ${ }^{303}$ Once he established that India behaved in ways indicating that it considered Portugal the sovereign over the enclaves, Wellington Koo commented that the fact that an enclaved land has been able to enjoy passage through the surrounding land of another state is "based upon. reason and the elementary principle of justice." ${ }^{304}$

Another disagreement on the Court that cannot go unmentioned, one between Kojevnikov and Winiarski, hints to a split along lines of legal tradition. Judge Kojevnikov's brief and unexplained refusal to accept jurisdiction contrasts with Judge Winiarski's joint dissent with Badawi wherein, based on an analysis of the facts and arguments of the parties, they reject the Court's position on the sixth preliminary objection and find the origin of the dispute at an earlier date.

This prima facie divergence, however, might not be a split at all as Winiarski's education was considerably more eclectic than that of the Soviet judge. Recall that Winiarski studied in Paris and Heidelberg in addition to Cracow and Warsaw and that Socialism had not been 
introduced into poland until after his education. So although Winiarski identified himself as a Socialist, his civil law education combined with what may be a civil law tendency to perceive of his judicial function as more participatory (when compared to the Soviet perception) may have made a strong imprint on his judicial role in this case.

Kojevnikov, on the other hand, studied law in Moscow immediately after the introduction of Socialism. This was also the era of "legal nihilism" when law schools and the legal profession were downplaying the importance of law including the role of the judge. One might be able to explain Kojevnikov's brief declaration as indicative of his Socialist legal education which did not place high value on the practice of writing as it did on oral presentation. Kojevnikov's brief and terse declaration corresponds with the expectation that Socialist judges at the World Court would continue to display some of the habits they learned as students of Socialist law. The fact that he dissented does not contradict the expectations stated in Chapter Two as it was noted that the role of the Socialist judge on the World Court is 
dramatically different than her or his role in the Socialist state and as such one would expect to see dissenting opinions delivered by Socialist judges.

It was also noted in Chapter Two that a short opinion might obscure any evidence of ideological predispositions in the opinion of a socialist judge. Kojevnikov supported India's preliminary objections and objected to the Court's reasoning on the grounds that Portugal did not in 1954 or at any point prior to that time have sovereignty over the enclaves. These statements are brief and make no reference to a Socialist ideology, thus any conclusions drawn from this opinion regarding his Marxist-Leninist mentality would be highly speculative. However, one might consider that the socialist legal tradition is resentful of what socialists perceive as western imperialism and it places a high value on state sovereignty.

Finally, Spiropoulos submitted a declaration testifying to his agreement with Spender, Armand-Ugon, and Wellington Koo on the submissions of Portugal on the merits. Perhaps Spiropoulos's agreement with what appear to be two different types of arguments symbolizes what 
one would want to conclude from the observations above. It appears in this case that even if civil law or common law methods of discovering and applying the law can be found in the dissenting opinions of a few justices, specifically Badawi, Armand-Ugon, Kojevnikov, and Winiarski, most of the justices appear to be deciding cases according to some other approach. Spender and Wellington Koo, although they seemed to have predominantly applied common law methods of reasoning, appear to have discovered and applied the law in a way similar to the majority, combining common law and civil law techniques. The only disagreement between the opinions of those two, Spender and Wellington Koo, and the majority was their interpretation of the facts.

There is evidence which indicates that the civil law dissenters may have employed methods of discovering and applying the law traceable to their legal education, but the majority and the common law dissenters appear to be adhering to the rules of international law which have created for the justices a particular role with identifiable constraints. Also, it is more likely that Moreno Quintana was motivated in his decision by 
political convictions rather than legal concerns.

Finally, it seems reasonable to suppose that the source of disagreement between Kojevnikov and Winiarski might be attributable to their distinct legal educations since both justices represented Socialist states.

The general conclusion that one must draw from the analysis of the Right of Passage Case, then, is that legal tradition appears not to have been a variable in the decision-making process of most of the judges but may have determined, albeit to what degree is unknown, the way in which three or four of the dissenters, civil law and socialist judges, discovered and applied the law. 
CHAPTER FOUR

ICJ II: THE NORTH SEA CONTINENTAL SHELF CASES, JUDGMENT $(20$ February 1969) 305

\section{Facts and Arguments:}

Prior to submitting their dispute to the ICJ, Germany, The Netherlands and Denmark had attempted to resolve a disagreement over the delimitations of the continental shelf in the North Sea. The Netherlands and Denmark insisted that the delimitation was governed by a mandatory rule of law which, reflecting the language of Article 6 of the Geneva Convention on the Continental Shelf, was designated as the "equidistance-special circumstances rule." 306

The effect of this rule is that in the absence of agreement by the Parties to employ another method, all continental shelf boundaries must be drawn by means of an equidistance line, unless or except to the extent to which "special circumstances" are recognized to exist. Denmark and The Netherlands stressed that this rule was binding on Germany independently of any specific assent, 
direct or indirect. ${ }^{307}$

The two countries advanced an additional, and more abstract argument. They argued that the positive law supportive of their position could be augmented by the natural law governing delimitation of continental shelves.

The supremacy of the equidistance-special circumstance rule could be found, in addition to written agreements, through the exercise of reason; it was an a priori and necessary rule of delimitation to be applied towards a resolution of this dispute. ${ }^{308}$

Germany continually objected to the resolution proposed by the other two countries. Instead, it invoked the "just and equitable share" principle which allocates to the state an amount of the continental shelf in proportion to the length of its coastline or sea frontage. ${ }^{309}$ Germany additionally argued that the nature of the shelf created a situation whereby all of the countries were entitled to a piece of the central portion. ${ }^{310}$

In a joint agreement to submit their dispute to the ICJ, the parties asked the Court to answer the following 
question: "What principles and rules of international law are applicable to the delimitations as between the parties of the areas of the continental shelf in the North Sea which appertain to each of them beyond the partial boundary determined by the above-mentioned Convention of 1 December 1964?"311

\section{Judgment:}

By a vote to 11 to 6 the court found

a) the use of the equidistance method for delimitation not being obligatory on Parties;

b) there being no other single method of delimitation the use of which is in all circumstances obligatory;

c) the principles and rules to be applied to this particular delimitation are as follows:

1. delimitation is to be effected by agreement in accordance with equitable principles, and taking account of all the relevant circumstances, in such a way as to leave as much as possible to each Party all those parts of the continental shelf that constitute a natural prolongation of its land territory into and under the sea, without encroachment on the natural prolongation of the land territory of the other;

2. any overlappings are to be divided between them in agreed proportions.

d) in the course of the negotiations, the factors to be taken into account are to include:

1. the general configurations of the coasts of the 
Parties, as well as the presence of any special or unusual features;

2 . the physical and geological structures of the areas involved.

3. the element of a reasonable degree of proportionality. ${ }^{312}$

Majority $=$ M

Dissent $=D$

Separate opinion $=$ so

JUDGES-TRADITION
\begin{tabular}{|l|c|}
\hline Rivero - Civil & VOTE \\
\hline Koretsky - social & DO \\
\hline Fitzmaurice - comm & M \\
\hline Tanaka - comm/civ & D \\
\hline Morelli - civil & D \\
\hline Zaf. Khan - common & M \\
\hline Lachs - civ/com/soc & D \\
\hline P. Nervo - civ/com & SO \\
\hline Forster - civil & M \\
\hline Gros - civil & M \\
\hline Ammoun - civil & SO \\
\hline Bengzon - civil & D \\
\hline Petren - civil & M \\
\hline Onyeama - common & M \\
\hline Jessup - common & SO \\
\hline
\end{tabular}

The majority of the Court dismissed Germany's request for a delimitation of the North Sea continental shelf on the basis of the just and equitable share principle. "Delimitation of a continental shelf," the judgment read, "must be equitably effected, however, it 
cannot have as its object the awarding of an equitable share."313 Characterizing the just and equitable share doctrine as "wholly at variance with the most fundamental of all the rules of law relating to the continental shelf," the Court proceeded to answer Denmark and the Netherlands contention: Does the equidistance-special circumstance principle constitute a mandatory rule, on either a conventional basis or according to customary international law? $?^{314}$

The Court quickly struck down the two states' argument based on natural law stating that with regard to the relations of states, no obligation is known prior to practice. ${ }^{315}$ It then turned to the positive law presented by the states. After reviewing treaty history, discussions of the International Law Commission, committees of experts on delimitation, and international conferences regarding continental shelf delimitation, the Court concluded that the principle of equidistance had at no time been regarded as an inherent necessity of continental shelf doctrine. ${ }^{316}$

The majority further disagreed with Denmark and the Netherlands on their contention that the principle of 
equidistance had developed into a rule of customary international law as a result of its incorporation into the Geneva convention. ${ }^{317}$ The Court agreed that such development can occur but observed that in the case of the equidistance principle, no such "hardening" had taken place. The Court pointed out moreover that the Geneva Convention had not received a sufficient number of ratifications and accessions to characterize it as normcreating for all states nor had it been in force long enough for what was a principle at its drafting to have developed into a rule of law at the time of the dispute. ${ }^{318}$

\section{Composition of the Court ${ }^{319}$ :}

Jose Luis Bustamante y Rivero, (Peru): At the civil law universities of Arequipa and Cuczo, Judge Bustamente y Rivero studied law and politics, philosophy, history and letters. Before entering a career in political office which included such positions as Ambassador to Uruguay and Minister to Bolivia, Bustamente $y$ Rivero was a practicing attorney and served in the Peruvian judiciary. He was a member of the ICJ from 1961-1970. 
Vladimir M. Koretsky, (U.S.S.R.): Judge Koretsky's legal career began with a Socialist legal education at the Universities of Moscow and Kharkov. From 1920-1949 he held a chair at Kharkov and was a member of a number of law societies. In the 1940's and 1950's Judge Koretsky represented his country on international committees. He served as a judge on the ICJ from 1961-1970.

\section{Sir Gerald Fitzmaurice, (Great Britain): Judge}

Fitzmaurice earned a common law legal education at Gonville and Caius College in Cambridge. After practicing as a private attorney, Fitzmaurice became legal adviser for his country. He represented Britain at numerous international conferences. He was a member of the ICJ from 1960-1973.

Kotaro Tanaka, (Japan): Like other Asian scholars, Judge Tanaka was educated in the law in a number of countries and thus, in a number of traditions. He earned his law degree from Tokyo Imperial University and subsequently traveled to the common law USA and civil law Europe to do 
post-graduate work in commercial law. In Japan Tanaka became a prolific writer and served as a tutor for the Crown Prince and Princess, member of the House of Peers, Minister of Education, and Chief Justice of the Supreme Court. He was a justice at the ICJ from 1961-1970.

Philip C. Jessup, (U.S.A.): Judge Jessup earned an LL.D from Hamilton College, a Ph.D. from Columbia University, and LL.B. from Yale University, all common law institutions. He was a member of a law firm throughout much of his legal career and concurrently taught at Columbia and served as Assistant Solicitor at the State Department. Jessup represented the U.S. at many international congresses. He served as a judge at the ICJ from 1961-1970.

Gaetano Morelli, (Italy): Judge Morelli earned his Doctor of Law in Rome, a civil law country, and for the next forty years taught at universities across Italy. He also performed diplomatic functions for his native country and was a member of many legal societies. He was a member of the ICJ from 1961-1970. 
Muhammad Zafrulla Khan, (Pakistan): Discussed in previous study, p. 90 .

Manfred Lachs, (Poland): Before entering the London School of Economics, Judge Lachs studied law in Vienna and Nancy at civil law institutions. He remained in England throughout World War II and began his international legal career there. Once back in Poland Judge Lachs became an international representative for his country. He served on the ICJ from 1967-1993.

Luis Padilla Nervo, (Mexico): Although he earned one law degree from the University of Mexico, a civil law institution, Judge Padilla Nervo earned a second at George Washington University, a common law institution. He also studied law in Buenos Aires and the London School of Economics before embarking on a career as a Mexican ambassador and public official. He was a member of the ICJ from 1964-1973.

Isaac Forster, (Senegal): Judge Forster graduated from 
the Lycee Hoche in Versailles and received a law degree from the Paris Law faculty, a civil law institution. Most of his career was spent in the senegalese judiciary; however he also served as a representative for his country at many international conventions and commissions. He was a justice at the ICJ from 1964-1982.

Andre Gros, (France): Judge Gros earned a civil law education at Lyons and Paris Universities. He subsequently entered a career in academia, lecturing across France, in Argentina, and at The Hague. From 1947-1963, he held a position in the Legal Department of the Foreign Ministry and throughout those years represented France at numerous international conferences. He was a member of the ICJ from 1964-1984.

Fouad Ammoun, (Lebanon): After earning a Bachelor of Law at Beirut School of Law, Judge Ammoun traveled to Lyon, where he earned his Doctor of Law under the civil law tradition. He occupied many positions in the Lebanese government and judiciary serving as legal adviser, ambassador, Secretary-General, and Chairman of.several 
national, regional, and international committees. He was a justice at the ICJ from 1965-1976.

Cesar Bengzon, (Philippines): Judge Bengzon earned a Bachelor of Laws at the University of the Philippines in 1919. He immediately went to work for the Bureau of Justice and eventually became Chief Justice of the supreme court. In addition to teaching law at the Philippine universities, Judge Bengzon performed diplomatic functions for his government. He was a member of the ICJ from 1967-1976.

sture Petren, (Sweden): As a student at Lund University, Judge Petren earned a civil law degree and a degree in the Humanities. The many positions he filled in government include but are not limited to Associate Judge at the Court of Appeals, Director of Legal Department at the Ministry of Foreign Affairs, Ambassador, legal adviser, Professor, and member of International commissions. He served on the ICJ from 1967-1976.

Charles D. Onyeama, (Nigeria): Judge Onyeama's education 
began in Nigeria where he attended several schools of government. He earned his LL.B. at London University and studied law at Brasenose College in Oxford, both common law institutions. After serving for the Nigerian legislature, Judge Onyeama began a career in the judiciary where he eventually became Chief Justice of the Nigerian Supreme Court. He was a member of the ICJ from 1967-1976 .

\section{Analysis:}

Again, it appears from the votes that the majority of the Court did not discover and apply the law in a way reflective of their respective legal traditions. The analysis of the judgment supports this observation. Of the justices who composed the Court's decision in the North Sea Cases, three were educated under the common law, three were educated in the civil law and one, Judge Padillo Nervo, was educated in both the civil law and common law traditions. One common law judge, Jessup, and two civil law judges, Bustamante y Rivero and Ammoun, delivered separate opinions. 
The civil law and common law justices representing the majority in this case reasoned the legal dispute and employed a method of finding the law similar to the court in the Right of Passage Case. Here, as in the earlier case, the Court's judgment hinged on state practice and other observable factors. In fact the Court quickly struck down the natural law argument proposed by Denmark and the Netherlands by insisting that there existed no legal obligation, known prior to state practice, to use the equidistance method of delimitation.

The Court proceeded to review the positive law on delimitation in order to find the law applicable to the particular dispute. From an examination of the Truman Proclamation, records of the ILC, the conclusions of committees of experts on delimitation of continental shelves, conferences on delimitation and the history of state practice with regard to delimitation, the court found two rules of law that have historically governed delimitation. It then instructed the Parties to adhere to these particular rules when delimiting the shelf in the North Sea.

The point of contention that occupied much of the 
Court's time concerned the legal status of Article 6 in the Geneva Convention which, Denmark and The Netherlands argued, advanced the status of the equidistance method from a legal principle to a rule of international law. The Court's disagreement with this claim rested wholly on its observation of state practice or more accurately, the lack thereof, with regard to delimitation based on the equidistance principle. More importantly, it refused to find customary law in a treaty that, in its opinion, had few accessions and ratifications. The court chose not to find international law in a document that, in its analysis, was not binding on all states. Thus on the matter of the Geneva Convention, the Court put the lawmaking authority back into the hands of the states which, through their interactions, could advance a nonobligatory principle of law to an obligatory rule of law. Although this self-imposed limitation suggests a civil law-like approach to the application of law, one can find little or no evidence in this judgment of a traditional civil law approach to finding the law. There is no discussion or any hints of concern about what justice requires or what the "correct" answer to the 
dispute might be. Moreover, the court not only bases its decision on concrete evidence, but it flatly rejects the two abstract arguments it is presented: the argument for equidistance based on natural law and the argument for equidistance based on its evolution into customary international law. Because it was unable to find any hard evidence supportive of the claim that the idea of equidistance as a rule of law had been accepted by states or known to them regardless of their assent, the court subsequently rejected that claim. One cannot infer from this observation, however, that the more abstract arguments were rejected solely because of the fact of abstraction. Rather, what appears to concern the Court is the lack of factual evidence to support the abstract claims.

Again, it appears that the Court's decision is more reflective of an adherence to rules and principles of international law than the practices of a particular legal tradition. The majority represents almost equally the common law and civil law traditions and the judges' discovery and application of the law reflects methods and habits from both of the traditions. The judgment 
manifests the common law's emphasis on facts and the creation of law through concrete events yet evinces a self-imposed limitation on the part of the justices reminiscent of the civil law. The Court's instructions for the delimitation appear to be a product of common law-like reasoning but fall short of qualifying as a pragmatic resolution. The guidelines they set instead look more like an outline of the principles to which the parties must conform in the process of delimitation.

None of the separate opinions filed in this case represent a sharp divergence from the reasoning of the judgment. However one of the four separate opinions does seem to lend weight to the proposition that legal education and training of the justices determine how they discover and apply the law. Whereas the opinions of Padillo Nervo, Bustamante y Rivero, and Ammoun do not constitute a deviation from the majority on the discovery or application of the law, Judge Jessup's opinion appears to be representative of the common law tradition.

Bustamante $y$ Rivero, a judge educated under the civil law, submitted a reservation regarding one paragraph in the Court's decision wherein a comparison was made 
between drawing lateral boundaries on an equidistance basis for territorial waters and doing the same for delimitation of a continental shelf. ${ }^{320}$ Bustamante $y$ Rivero expressed concern over bringing territorial water delimitation into the decision as it is also a controversial issue between states and also was not a source of the dispute in the present case..$^{321}$

Civil law judge Padillo Nervo chose to append a separate opinion for the purposes of further justifying the Court's rejection of the argument that Article 6 of the Geneva Convention had evolved into customary international law. ${ }^{322}$ He examined in greater detail the principles agreed upon by the Parties to the Geneva Convention prior to its drafting and concluded that the States at Geneva "did not intend to accept the equidistance method as a general rule of law from which they could not depart and which would be binding on them in all cases. " ${ }^{323}$

Judge Ammoun, educated under the civil law, agreed with the Court's position that the equidistance principle was not opposable as a rule of treaty-law to Germany..$^{324}$ He nonetheless argued that the Parties could employ the 
equidistance-special circumstances method as derived from the general principle of law equity praeter legem. ${ }^{325}$

In an opinion which seemed to be directed more to the Parties than to the Court itself, common law judge Jessup pointed out that that the real issue underlying the dispute over the delimitation of the North Sea involved the exploitation of the oil and gas resources. ${ }^{326} \mathrm{He}$ expressed curiosity over why the Parties chose to argue on other legal principles which were "sometimes advanced with almost academic detachment from realities." ${ }^{327} \mathrm{He}$ even appeared to be advising the Parties as to how they ought to proceed with the negotiations as he discussed the possibility of an agreement between the Parties based on the principle of joint exploitation of the resources in the continental shelf. ${ }^{328}$ Lastly, Jessup reminded the Parties of their right to return to court in the event that they need further guidance during the process of negotiation. ${ }^{329}$

Undoubtedly, Justice Jessup's perception of the role of the Court in this dispute was quite different from the perception of the majority and Bustamente $y$ Rivero and Padillo Nervo. Jessup goes beyond directly answering the 
question submitted by the Parties and advises them on how they might have presented a better argument. He in fact informs them that their arguments exclude the real problem at hand, division of economic resources, and thus miss the point. He offers suggestions about negotiation that were not raised by the Parties or the court and in the end extends an invitation to the Parties to return to Court if they are unable to reach a resolution. Clearly, in this case Jessup views his role on the Court as involving more than strict application of the law created by states. Indeed Jessup typifies the common law judge; he steps outside of the limits imposed on him and the other justices by the Parties and proceeds to address issues and problems with which he is troubled. Although he doesn't appear to be trying to create law in his opinion, Jessup does appear to be trying to define for the states the dispute between them. He is essentially telling the States that they misunderstood the problem or at least misrepresented it and that he understands it correctly.

Jessup's common law roots are even more evident in his suggestion to the Parties that they consider joint 
application as a remedy for the problem. He appears to be more concerned with a practical, workable solution to the problem and is willing to state it in his own opinion rather than confine himself to the majority's more vague and principled set of instructions. In this case, then, Jessup meets the expectations one might have of a common law judge on the World Court. He affirms the majority's reasoning, which I identified as reflective of common law, and subsequently applies the law in a flexible and creative manner representative of the common law tradition.

The dissenters were a slightly more diverse group then the majority. They included the only judge educated under a Socialist system, Koretsky, plus two justices educated in civil law systems, Bengzon and Morelli, and one justice, Tanaka, who was educated under the Asian legal tradition and both common and civil law. The dissenting group also included a justice who represented the Socialist state but was educated under the civil law and underwent formative training in a common law legal system, Manfred Lachs.

Koretsky proposed a different interpretation of how 
a principle in international law becomes a rule binding upon all states. He argued that the function of international conferences and treaty-making is to codify principles and rules that have taken shape in state practice, in essence it is to express the opinio juris regarding particular state practices..$^{330}$ Koretsky reasoned that the principles and rules embodied in the Geneva Convention, including the equidistance-special circumstances method, were thus part of customary international law and applicable to this dispute. ${ }^{331}$ Finally, he observed that not one of the parties to the Geneva Convention opposed in any general way the principles and rules embodied in Article 6, although some states had reservations about specific geographical locations. ${ }^{332}$

One could not conclude that Judge Koretsky discovered and applied the law in a manner reflective of the Socialist legal tradition under which he was educated. His opinion does reveal what one might consider more abstract and theoretical concerns, however, as I demonstrated in Chapter Two, the civil law tradition is equally as concerned with substantive, philosophic 
problems as the Socialist legal tradition. Further support for this conclusion lies in Koretsky's lengthy and explanatory dissenting opinion which directly contradicts the expectations for a Socialist judge laid out in Chapter Two.

The other judge trained in Socialist law, Lachs, came to a conclusion similar to Koretsky. Lachs found evidence for claim that the equidistance principle had become a principle of customary international law obligatory on all states in state practice and in the fact that it is part of the Geneva Convention and has been accepted by the International Law Commission. ${ }^{333}$ Lachs argued that the object and purpose of the Geneva Convention, as with all multilateral treaties, limits the freedom of states to make reservations to wellestablished principles of international law. ${ }^{334} \mathrm{He}$ objected to Germany's claim that if the equidistance method applied to this dispute the special circumstances rule would have to go into effect because the method would allot Germany a lesser portion of the continental shelf than the Netherlands and Denmark. Lachs insisted that a lesser portion does not constitute "special 
circumstances. " 335

In light of his diverse background, it seems that one cannot pinpoint which legal tradition, if any, might have determined the way in which Lachs discovered and applied the law in this case. He is clearly looking at the dispute as a matter of legal principle and he worries more about the theoretical evolution of law than the formation of law as evidenced in state practice. This perspective is representative of the civil law tradition and the socialist legal tradition which it influenced. On the other hand, Lachs does not ignore state practice and opinio juris and finds examples of the equidistance method being employed by states. This attention to the historical facts and the lengthy, assertive dissenting opinion reveal Lachs's common law roots. It appears in Lachs's case, then, that one cannot know for certain if it was the civil law legal education that influenced his opinion or his training under the common law and then Socialist law.

One is led to make similar conclusions about Judge Tanaka's dissent. Tanaka began by mentioning five Agreements between states as examples of the application 
of the equidistance principle concerning the North Sea continental shelf and thus, as evidence for the recognition as customary international law this method of delimitation on the basis of state practice. ${ }^{336} \mathrm{He}$ proceeded to analyze the process known as customary international law, characterizing it as sociological process. He acknowledged that the formation of the equidistance method as a principle customary international law was speedy and attributed this speediness to a number of sociological factors including the Geneva Convention. ${ }^{337}$ He remarked that although it may not have been signed by all states, "the coming into existence of the Geneva Convention itself would psychologically and politically facilitate the adherence of the non-party states to the Convention or the introduction of the equidistance principle into their practice." ${ }^{338}$ Tanaka cited additional factors for his position including the urgent necessity of avoiding international conflict between coastal states, and the fact that a vacuum existed in the law of continental shelf that was filled by the Geneva Convention. ${ }^{339}$ Tanaka distinguished between legal positivists and 
others who see law as existing apart from the states and placed himself in the latter category. He stated that the essence of law is that it is "an objective order vis a vis those who are subject to it, and governing above them..."340 Finally, he admonished the court for failing to take advantage of the opportunity presented to it in this case to make a contribution to the progressive development of international law. ${ }^{341}$

Tanaka's opinion does not fit neatly into one legal tradition. Instead, it embodies methods that one might associate with at least two legal traditions. His immediate focus on factual evidence is typical of a common law approach to discovering law. His critical analysis of the theoretical construct known as customary international law is characteristic of a civil law approach to discovering law.

The position he takes on the law in opposition to the positivist approach might also be considered characteristic of a civil law approach to judicial decision. However, it might be more reflective of the Asian legal tradition under which Tanaka spent most of his legal career. Although the Asian legal tradition is 
not part of the focus in this project, I think it appropriate to submit that the idea of law as an objective order independent of its subjects is fundamental to the Japanese legal order. ${ }^{342}$ Moreover, the heavy influence of both common law and civil law on the Japanese legal system makes a determination about whether Tanaka's methods for discovering and applying the law were a result of education in civil law and common law countries or the outcome of his history as a Japanese legal professional very difficult to make. ${ }^{343}$

The final dissenter was Justice Morelli, a civil law judge. Morelli disagreed with the Court's rejection of the equidistance method as a principle of customary international law binding upon Germany for the delimitation of the North Sea. His analysis of the dispute and of the questions of law at hand was representative of the quintessential civil law judge. He devoted most of his opinion to an exegesis of the principle of equidistance in general and to the principles of law governing the delimitation of continental shelves. His support of the equidistance principle rested on the international legal principle 
known as contiguity and not on state practice:

I consider the rule of general international law prescribing the equidistance criterion for the delimitation of the continental shelve of various states to be a necessary consequence of the apportionment effected by general international law on the basis of contiguity. I am therefore of the opinion that it is not necessary to ascertain if a specific custom has come into existence in this connection. State practice in this field is relevant not as a constitutive element of a custom which creates a rule, but rather as a confirmation of such rule. Confirmation of the rule is also provided, within certain limits, by the provisions of the Geneva Convention. ${ }^{344}$

Morelli argued that written agreements between states are only declaratory in character and do no more than "record a situation which has already arisen automatically." ${ }^{345}$ In his search for the law, Morelli did not at any point engage in a discussion of the particular facts of the delimitation of the North Sea. Instead, he sought to access and explain the abstract principles of international law existing prior to international agreements and state practice in the area of continental shelf delimitation. He began with an analysis of the rights conferred upon states regarding continental shelves and proceeded to deduce to the rule or criterion of apportionment known as contiguity. ${ }^{346}$ His argument 
hinged on the logical procession from the notion of contiguity to the idea of proximity which led, finally, to the principle of equidistance. ${ }^{347}$

Justice Morelli appears to have perceived his role as judge as a relatively modest one. He reasoned through the problem from a strict theoretical approach and did not appear to be attempting to make new law or to be directing states to develop better law. He found what he believed to be the law by inferring from international legal principles; he did not make broad statements about how states should or should not be acting nor did he pronounce on what the role of international law and the Court ought to be. Justice Morelli appears to have applied the law in civil law-like fashion.

The analysis of the votes and decisions in the North Sea Cases indicates that, with the exception of perhaps two justices, the legal tradition under which a justice was educated and trained did not determine the way in which he discovered and applied the law in this case. The majority was represented, almost equally, by the civil and common law traditions, and from the analysis of the judgment one is led to conclude that the judges 
appear to have been guided more by the constraints established for them by international law than by the legal traditions under which they studied law and became legal professionals.

of the four individuals who filed separate opinions, Justice Jessup, a common law judge from the United States, is the only one whose discovery and application of the law seemed to reflect the legal tradition under which he was educated and trained. Finally, one of the dissenting opinions, Justice Morelli's could be characterized as highly representative of the legal tradition under which its author was educated and trained. All of the other dissenters employed methods for either discovering or applying the law which were typical of the legal tradition under which they were educated and/or trained but also employed methods characteristic of other legal traditions.

One might conclude that the opinions of Tanaka and Lachs were reflective of their diverse legal experience. Recall that these justices had an eclectic legal background each having affiliations with three different legal traditions. While it might be the case that these 
justices discovered and applied the law in ways typical of their legal background, one should be cautious about drawing such a conclusion from this analysis. Since most of the other justices employed methods for deciding the case that are representative of more than one legal tradition, the opinions of Tanaka and Lachs are not unusual in that respect. 
CHAPTER FIVE

ICJ III: THE CASE CONCERNING CERTAIN PHOSPHATE ILANDS IN NAURU, JUDGMENT (PRELIMINARY OBJECTIONS) (JUNE 26, $1992)^{348}$

\section{Facts and Arguments:}

The factual point of origin of this case is a trusteeship established by the United Nations over the now independent state of Nauru located in Micronesia. In 1947 three states, Australia, the United Kingdom, and New Zealand were established as the Administering Authority (AA) vested with the authority to exercise the administration of Nauru. ${ }^{349}$ In 1951 the Nauru Local Government Council (NLGC) was created to represent the Nauruan community and to perform local administrative functions. ${ }^{350}$

According to Nauru, in the following decade and on several occasions, the NLGC approached the United Nations with concerns about the rehabilitation of phosphate lands in Nauru which had been worked-out to near depletion by 
the British Phosphate Commissioners under the leadership of the AA..$^{351}$ Specifically, Nauru requested that the states composing the $\mathrm{AA}$ bear responsibility for financing the rehabilitation of the lands. An attempt to resolve the issue was made in 1967 with the promulgation of an Agreement between the NLGC, on the one hand, and the three states of the $A A$, on the other, by which, according to Australia, Nauru waived its claims to rehabilitation of the phosphate lands by the states composing the AA. ${ }^{352}$ Ellen Fitzgerald identifies the fundamental legal issue in this case as the nature of the trust obligation in international law..$^{353}$ She argues that the Court, in reaching a decision in this case, would be faced with the following questions: What was the character of the "sacred trust" in which Australia supervised the social, political and economic existence of Nauru until its independence in 1968? In examining the nature of the trusteeship in general, can one test its potency to determine when or how such a trust is violated? What are the consequences of such a breach? ${ }^{354}$ Ramon E. Reyes, Jr. agrees that the nature of a trust lies at the heart of this dispute and comments that this case "raised 
interesting questions of international law concerning accountability for the operations and conduct in a trust territory. " ${ }^{355}$

Antony Anghie finds additional significant legal issues framing this dispute. He notes that the case "is the first instance of a former dependent territory bringing action against a metropolitan authority for abusing its power when administering the dependent territory." ${ }^{356}$ Thus it raises the issue of colonialism. Additionally, Anghie observes, the case also presents "the stark plight of a people whose verdant island home. has been transformed by mining into a scarred wasteland." 357 Thus, it confronts the Court with the question of environmental damage and when and how to remedy it..$^{358}$

As this judgment was on the preliminary objections and not on the merits, the Court, at this phase, did not have to adjudicate on some of these larger legal issues identified above. Nauru's claims and Australia's objections submitted at this phase were intended to address the question of the Court's jurisdiction and the admissibility of Nauru's application. 
In its pleadings and in oral arguments before the Court, Nauru argued that the Agreement did not resolve the matter of rehabilitation of the phosphate lands and that when the Trusteeship was terminated in 1968 the dispute was still unsettled. ${ }^{359}$ Nauru asked the Court to adjudge and declare that Australia, due to its failure to finance the rehabilitation of the worked out phosphate lands in Nauru, bears responsibility for breaching the following obligations: 1) Article 76 the U.N. Charter and Articles 3 and 5 the Trusteeship Agreement for Nauru; 2) the international standards generally recognized as applicable in the implementation of the principle of self-determination; 3) the obligation to respect the right of the Nauruan people to permanent sovereignty over their natural wealth and resources; 4) the obligation of international law not to exercise powers of administration in such a way as to produce a denial of justice lato sensu; 5) the obligation of general international law not to exercise powers of administration in such a way as to constitute an abuse of rights; 6) the principle of general international law that a state which is responsible for the administration 
of territory is under an obligation not to bring about changes in the condition of the territory which will cause irreparable damage to, or substantially prejudice, the existing or contingent legal interest of another State in respect of that territory. ${ }^{360}$

Nauru requested that the court find that it has a legal entitlement to the Australian allocation of the overseas assets of the British Phosphate Commissioners which were marshalled and disposed of in accordance with the trilateral Agreement rather than shared with the Nauruan people. ${ }^{361}$ Lastly, it asked the Court to declare that Australia was under a duty to make appropriate reparation in respect of the loss caused to Nauru as a result of the breaches of its legal obligations. ${ }^{362}$ In its defense, Australia advanced preliminary objections to the application. First, it invoked its reservation to the optional clause excluding from the Court's jurisdiction all those disputes between Australia and other states which "the parties thereto have agreed or shall agree to have recourse to some other method of peaceful settlement." ${ }^{363}$ Second, it asserted that Nauru had, during debates at the United Nations, waived any 
claims to rehabilitation of the phosphate lands by Australia. ${ }^{364}$ Australian officials argued third that their government had been discharged of any obligation to finance the rehabilitation in Nauru once the Trusteeship had been terminated. ${ }^{365}$ Fourth, they objected to the Court's jurisdiction and inadmissibility of the application on grounds that Nauru had allowed an unreasonable amount of time to pass before its officials filed a complaint with the Court. ${ }^{366}$ Fifth, Australia argued that Nauru had failed to act in good faith with regard to the rehabilitation ${ }^{367}$. Sixth, it objected to the dispute on grounds that New Zealand and the United Kingdom were part of the $A A$ yet were not parties to the case and that a judgment by the Court would effect New Zealand and the U.K. ${ }^{368}$ Lastly, Australia contended that Nauru's claim regarding the overseas assets of the BPC was a new one. ${ }^{369}$ Australia argued that for all of the reasons stated above Nauru's application to the Court was inadmissible and the court lacked jurisdiction in this matter.

\section{Judgment:}


The court voted as follows:

1) 13 to 0 - rejected the preliminary objection based on Australia's reservation to the optional clause.

2) 12 to 1 - rejected the preliminary objection based on an alleged waiver by Nauru, prior to accession to independence, of all claims concerning the rehabilitation of the phosphate lands worked out prior to 1 July 1967.

3) 12 to 1 - rejected the preliminary objection based on the termination of the trusteeship over Nauru by the United Nations.

4) 12 to 1 - rejected the preliminary objection based on the effect of the passage of time on the admissibility of Nauru's application.

5) 12 to 1 - rejected the preliminary objection based on Nauru's alleged lack of good faith.

6) 9 to 4 - rejected the preliminary objection based on 
the fact that New Zealand and the United Kingdom were not parties to the proceedings.

7) 13 to 0 - upheld the preliminary objection based on the claim concerning the overseas assets of BPC being a new one.

8) 9 to 4 - found that it has jurisdiction and the application is admissible.

9) 13 to 0 - found that the claim regarding overseas assets is inadmissible. ${ }^{370}$

Majority $=M$

Dissent $=D$

Separate Opinion = so

\begin{tabular}{|c|c|c|c|c|c|c|c|c|c|}
\hline JUDGES-TRADITION & 1 & 2 & 3 & 4 & 5 & 6 & 7 & 8 & 9 \\
\hline Jennings - common & $\mathrm{M}$ & $\mathrm{M}$ & $\mathrm{M}$ & $\mathrm{M}$ & $\mathrm{M}$ & $\mathrm{D}$ & $\mathrm{M}$ & $\mathrm{D}$ & $\mathrm{M}$ \\
\hline Oda - common/asian & $\mathrm{M}$ & $\mathrm{D}$ & $\mathrm{D}$ & $\mathrm{D}$ & $\mathrm{D}$ & $\mathrm{D}$ & $\mathrm{M}$ & $\mathrm{D}$ & $\bar{M}$ \\
\hline Lachs - civ/com/soc & $\mathrm{M}$ & $\mathrm{M}$ & $\mathrm{M}$ & $\mathrm{M}$ & $\mathrm{M}$ & $\mathrm{M}$ & $\mathrm{M}$ & $\mathrm{M}$ & $\mathrm{M}$ \\
\hline Ago - civil & $\mathrm{M}$ & $\mathrm{M}$ & $\mathrm{M}$ & $\mathrm{M}$ & $\mathrm{M}$ & $\mathrm{D}$ & $\mathrm{M}$ & $\mathrm{D}$ & $\mathrm{M}$ \\
\hline Schwebel - common & $\mathrm{M}$ & $\mathrm{M}$ & $\mathrm{M}$ & $\mathrm{M}$ & $\mathrm{M}$ & $\mathrm{D}$ & $\mathrm{M}$ & $\mathrm{D}$ & $\mathrm{M}$ \\
\hline Bedjaoui - civil & $\mathrm{M}$ & $\mathrm{M}$ & $\mathrm{M}$ & $\mathrm{M}$ & $\mathrm{M}$ & $\mathrm{M}$ & $\mathrm{M}$ & $\mathrm{M}$ & $\mathrm{M}$ \\
\hline Zhengyu - com/asian & $\mathrm{M}$ & $\mathrm{M}$ & $\mathrm{M}$ & $\mathrm{M}$ & $\mathrm{M}$ & $\mathrm{M}$ & $\mathrm{M}$ & $\mathrm{M}$ & $\mathrm{M}$ \\
\hline Evensen - civ/com & $\mathrm{M}$ & $\mathrm{M}$ & $\mathrm{M}$ & $\mathrm{M}$ & $\mathrm{M}$ & $\mathrm{M}$ & $\mathrm{M}$ & $\mathrm{M}$ & $\mathrm{M}$ \\
\hline Tarassov - social & $\mathrm{M}$ & $\mathrm{M}$ & $\mathrm{M}$ & $\mathrm{M}$ & $\mathrm{M}$ & $\mathrm{M}$ & $\mathrm{M}$ & $\mathrm{M}$ & $\mathrm{M}$ \\
\hline Guillaume - civil & $\mathrm{M}$ & $\mathrm{M}$ & $\mathrm{M}$ & $\mathrm{M}$ & M & $\mathrm{M}$ & $\mathrm{M}$ & $\mathrm{M}$ & M \\
\hline Shahabudden - comm & $\mathrm{M}$ & $\mathrm{M}$ & $\mathrm{M}$ & $\mathrm{M}$ & $\mathrm{M}$ & SO & $\mathrm{M}$ & $\mathrm{M}$ & $\mathrm{M}$ \\
\hline Ranjeva - civil & $\mathrm{M}$ & $\mathrm{M}$ & $\mathrm{M}$ & $\mathrm{M}$ & $\mathrm{M}$ & $\mathrm{M}$ & $\mathrm{M}$ & $\mathrm{M}$ & $\mathrm{M}$ \\
\hline A. Mawdsley - civil & $\mathrm{M}$ & $\mathrm{M}$ & $\mathrm{M}$ & $\mathrm{M}$ & $\mathrm{M}$ & $\mathrm{M}$ & $\mathrm{M}$ & $\mathrm{M}$ & $\mathrm{M}$ \\
\hline
\end{tabular}


This judgment is significantly more one-sided than the previous two, i.e. the majority is quite larger in this case then in the others I have analyzed. This is not an oversight, rather, the cases decided in ICJ III thus far have not been as divisive as those in ICJ I and ICJ II. In the decisions that have been rendered during ICJ III up until the present, the justices have overwhelmingly voted together. This judgment represents the widest split of votes in this era.

One might have further noticed that this judgment is on the preliminary objections to the case. This is not problematic for the purposes of the study as questions of jurisdiction at the ICJ are substantive ones rather than procedural ones, as they are in municipal law, and thus, the justices are making decisions and reasoning about substantive law.

The only notable disagreement between the justices in this case was on the matter of the exclusion of New Zealand and the U.K. from the case, preliminary objections six and eight. The court refused to uphold 
these objections stating that it could think of no reason for declaring the Application inadmissible on these grounds. ${ }^{371}$ It noted that in this case the interests of New Zealand and the United Kingdom did not constitute the very subject-matter of the judgment and that although a finding by the Court regarding Australia's responsibility concerning the phosphate lands might well have implications for the legal situation of New Zealand and the U.K., no finding in respect of that legal situation would be needed as a basis for the Court's decision. ${ }^{372}$

The Court further noted that states which are not part of this case have permission to intervene. ${ }^{373}$ The Court ruled that the absence of the other states in the case, however, "in no way precludes the Court from adjudicating upon the claims submitted to it." ${ }^{374}$ The Court concluded that "the determination of the responsibility of New Zealand or the United Kingdom is not a prerequisite for the determination of the responsibility of Australia." ${ }^{375}$

On the first preliminary objection, the court unanimously found Australia's reservation inapplicable to the present dispute. Nauru and Australia had not made 
any agreement to have recourse to some other peaceful method of settlement in the event of a dispute over the phosphate lands. ${ }^{376}$ The Court rejected the second preliminary objection, Australia's claim that Nauru had waived all claims related to rehabilitation of the phosphate lands. It found, through an investigation of negotiations for the 1967 Agreement and discussions at the United Nations that Nauruan authorities "did not at any time effect a clear and unequivocal waiver of their claims...". . 377

After an analysis of discussions between Nauru, the states comprising the $\mathrm{AA}$, and the United Kingdom during the process of terminating the trusteeship, the Court rejected the third preliminary objection. According to the Court, the facts showed that at the time of termination of the trusteeship, everyone involved in the termination, including the Trusteeship Council in the United Nations and representatives in the General Assembly, the members of the AA, and the Nauruans, was aware of persistent disagreements between the NLGC and the $A A$ with regard to the rehabilitation of the phosphate lands. And although the General Assembly resolution 
that terminated the trusteeship did not expressly reserve any rights for Nauru with regard to the lands, it also did not discharge the $A A$ with respect to such rights. ${ }^{379}$ The Court ruled that "the rights Nauru might have had in connection with rehabilitation of the lands remained unaffected. " ${ }^{380}$

Australia's fourth preliminary objection, regarding the unreasonable passage of time between Nauruan independence and the submission of the application to the Court, was also rejected. The court argued that an unreasonable passage of time may, in some instances, render an application inadmissible. However, since no specific time limits have been set for the filing of an application with the Court, the Court reasoned, it is the responsibility of the Court to determine, in each individual case, if an unreasonable passage of time has elapsed so as to render the application inadmissible. ${ }^{381}$ After reviewing the history of correspondence between Nauru and Australia with regard to the rehabilitation of the phosphate lands, the Court ruled that the application was admissible. ${ }^{382}$

The Court readily struck down the fifth objection, 
alleging a violation of the principle of good faith on behalf of Nauru. It noted that Nauru submitted its application properly and in accordance with the international judicial process and that any further judgment regarding good faith would amount to a decision on the merits. ${ }^{383}$

Lastly, the Court unanimously upheld Australia's seventh and eighth objections wherein it argued that Nauru's claim concerning the overseas assets of the British Phosphate Commissioners was a new one and thus inadmissible. The Court agreed that for a new claim to be admissible it must either been implicit in the application or it must have arisen directly out of the question which is the subject matter. ${ }^{384}$ It found that neither standard was met. The Court's examination of Nauru's application showed that no reference to the disposal of the overseas assets of the BPC appeared in it except for a submission at the end asking the court to declare that it has a legal entitlement to the assets. ${ }^{385}$ The justices also agreed that if they were to include this claim on the merits, the subject of the dispute would be necessarily altered. ${ }^{386}$ 
With the exception of the sixth and eight preliminary objections, the only dissents to the six questions before the Court were produced by one individual, Judge Oda from Japan, who dissented on all but three of the votes.

\section{Composition of the court: ${ }^{387}$}

Sir Robert Jennings, (United Kingdom): Justice Jennings was educated at Downing College, a common law institution in Cambridge, before being awarded a fellowship at Harvard University, another common law legal facility. He remained in academia as a lecturer and published many manuscripts on international law. He also served as legal adviser to various governments and as counsel in numerous arbitrations. Justice Jennings was a member of the ICJ from 1982 to 1995.

Shigeru Oda, (Japan): Judge Oda earned a law degree from the University of Tokyo and subsequently spent three years studying under a common law system at yale University. In Japan he became a full professor of International Law and a diplomat. Judge Oda has been 
extremely active in the academic community and in the international legal community. He has served on the ICJ since 1976 .

Manfred Lachs, (Poland): Discussed in previous study, p. 119.

Roberto Ago, (Italy): Judge Ago earned a doctorate of law and political sciences from the civil law University of Naples. He has served as a professor of international law at many Italian universities, headed a number of Italian delegations to international conferences, and served as counsel for various governments in cases before the World Court. Judge Ago served on the ICJ from 19791995.

Stephen M. Schwebel, (United States): Judge Schwebel holds a law degree from Yale University but also studied the law in Cambridge at Harvard College, both common law institutions. He has taught law at Harvard and Cambridge Universities, served as legal adviser in the Department of State, headed delegations to United Nations committees, and authored countless articles on various 
matters in international law. Judge Schwebel has been a member of the ICJ since 1981.

Mohammed Bedjaoui, (Algeria): Judge Bedjaoui holds a Diploma of the Institute of Political studies at the University of Grenoble. Although his official bibliography doesn't provide the name of the institution where he holds a Doctor of Law, it appears that he earned it either at the University of Grenoble or at an institution in Algeria. In either case, Bedjaoui was educated under the civil law. He has held many posts for the Algerian government including Legal Adviser, Secretary-General, Minister of Justice and Keeper of the Seals, and Ambassador to France. He has been a judge at the ICJ since 1982 .

Ni Zhengyu, (China): In China, Judge Zhengyu was educated at the Chitz, Soochow and Dongwu Universities. He received a Doctorate of Law from a common law school, Stanford University. Soon after he began a long tenure as Legal Counsel in the Ministry of Foreign Affairs and in this capacity represented the PRC at many international 
conferences. Judge $\mathrm{Ni}$ was a member of the ICJ from 19851994.

Jens Evensen, (Norway): Justice Evensen holds a law degree from Oslo University, a civil law institution and a Doctorate from Harvard Law School, a common law institution. He also studied under the common law system at Columbia and Minnesota Law Schools. Evensen was a public prosecutor and then a advocate at the Supreme Court of Norway. For over a decade he was the DirectorGeneral of the legal Department of the Foreign Ministry. He also attended many international conferences on behalf of Norway. Judge Evensen served on the ICJ from 19851994.

Nikolai konstantinovitch Tarassov, (U.S.S.R. \& Russia): Tarassov was educated in the law at the Law Faculty of Moscow University, a Socialist legal institution. He has occupied many positions for the Soviet and Russian governments including Consultant to the Legal Department of the Presidium of the Supreme Soviet, Head of the Secretariat for the Secretary of the Presidium, 
Counsellor at the U.S.S.R. embassy in Iran, and representative at the United Nations. Judge Tarassov was a judge on the ICJ from 1985-1994.

Gilbert Guillaume, (France): Judge Guillaume received a Bachelor's Degree in civil law from the University of Paris. He has been a Legal Adviser to France and a French representative at many international conferences. He was Director of Legal Affairs for France, representing the government in many cases, and a professor at the University of Paris. Judge Guillaume has been a member of the ICJ since 1987.

Mohamed Shahabuddeen, (Guyana): Judge

Shahabuddeen studied law at London University, a common law facility, where he obtained his LL.D. and Ph.D. In Guyana he was Solicitor General and then Attorney General. He also served as Minister of Justice and as representative of Guyana to many international meetings. Judge Shahabuddeen has been a member of the ICJ since 1988 . 
Andres Aguilax Mawdsley, (Venezuela): Judge Aguilar earned a Doctorate in Political and Social Sciences from Caracas University, a civil law institution, and a Master's Degree in Civil law from McGill University in Montreal. For one decade he was a lecturer in Venezualan universities but left the academic realm to pursue a career as a diplomat for his government. Judge Aguilar Mawdsley was on the ICJ from 1991-1995.

Raymond Ranjeva, (Madagascar): Judge Ranjeva also holds degrees from two different countries. In Madagascar he obtained a degree in law and administration and a diploma in political science and public law. In Paris, a civil law state, he earned another diploma in political science and public law and also a Doctorate of Law. Ranjeva has occupied many positions in academia and government including professor, Dean, Rector of the University of Antananrivo, delegate at international conferences, and counsel for Madagascar in international cases. He has been a member of the ICJ since 1991.

\section{Analysis:}


It is clear that legal tradition did not determine the way in which the justices discovered and applied the law in preliminary objections one, seven, and nine. This claim is justified by the fact that the Court was composed of a fairly diverse group of justices representing over five legal traditions and that there were no dissents on these votes.

Once again what stands out in the judgment is a method of discovering the law similar to the common law approach. In each decision, possibly with the exception of the sixth objection, the justices referred to the facts leading up to the dispute to make their decision. In almost every vote, their decision followed from a review of the discussions and correspondence that had taken place between Nauru, Australia (and the other states of the AA), and members of the bodies of the United Nations involved in the trusteeship.

This common law style is also manifested in the decision on the sixth objection involving the admissibility of the application in light of New Zealand's and the United Kingdom's absence. To demonstrate the law on this claim, the court reviewed 
past court decisions by the PCIJ and ICJ and national courts. Although the Court's deference to previous court rulings does not necessarily amount to an acceptance of the principle of stare decisis, this method for discovering the law is characteristic of the common law system founded on the notion of precedent and uncharacteristic of the civil law and socialist law traditions. ${ }^{388}$

The Court's application of the law does not appear to reflect any particular legal tradition, or perhaps more accurately it evidences elements of all three of the legal traditions examined in Chapter Two with no one of them overrepresented. The judgment does not signal a group of powerless, deferential judges looking outward for the law, as one might expect from a socialist or civil law judge.

Indeed, in its answer to the question of a reasonable time of passage, the Court stated without equivocation that it possesses the authority to determine what constitutes an unreasonable passage of time. Further, it upheld its jurisdiction over the case on the matter of the absence of the United Kingdom and New Zealand even 
though the law surrounding the legal interests of third states might be regarded as somewhat vague.

The Court, on the other hand, does not apply the law in traditional common law fashion. There is no evidence to suggest that the justices wielded expansive authority and created law apart from the law created by states. They concerned themselves strictly with the practice between Australia and Nauru and refrained from making declarations of law which had no basis in state practice or international agreements.

Judge Shahabuddeen filed a separate opinion for the purposes of explicating the reasons why he agreed with the Court on the sixth preliminary objection. He argued that even if one assumed that the obligations under question applied to all three of the states comprising the $A A$, the suit could be brought against Australia alone (as opposed to a suit against Australia, New Zealand, and the United Kingdom)..$^{389}$ He observed that Australia had been given the leading role in administering Nauru and that it had exclusive authority to administer Nauru for all practical purposes. ${ }^{300}$ Shahabuddeen dismissed Australia's claim that it did not 
possess authority over the phosphate industry stating that the extent of Australia's authority over Nauru was so great as to include the overwhelming bulk of the territory's economy. ${ }^{391}$ He concluded that the United Kingdom and New Zealand had virtually no input into the administration of Nauru. ${ }^{392}$

Shahabuddeen referred to statements made by the ILC and to municipal law, including the law of torts in English Law, and writings of publicists as supportive of the position that a state could be sued alone even if it shared the obligation at issue with another state or states. ${ }^{393}$ The judgment, he maintained, only applies to the state being sued and does not impose legal responsibility on the states absent from the case.

Shahabuddeen, a common law educated judge, appears to have reasoned the problem in a way similar to the majority. In fact he clearly states that his opinion does not diverge from the Court's judgment but supplements it and provides further support for its conclusions. Like the majority, Shahabuddeen discovers the law through an analysis of the facts of the case and applies it in a way that is not reflective of one legal 
tradition in particular. Also like the majority, Shahabuddeen's approach to decision-making cannot necessarily be attributed to his common law education as it was shown that the same approach was taken by civil law and Socialist law judges in the Court's judgment. Preliminary objections two, three, four, and five provide further support for the conclusion that legal tradition did not determine the decision-making of the majority. One justice, Oda from Japan, dissented on all of these four votes plus votes six and eight. An analysis of his dissent, however, shows that Oda took the same approach to discovering the law as the majority. In his decision, oda was primarily concerned with what he perceived to be Nauru's past silence on the matter of the rehabilitation of the worked-out phosphate lands. He meticulously reviewed all of the facts of the case, including all correspondence between Nauru and Australia and Nauru and the United Nations regarding the rehabilitation of the lands and found that Nauru failed, on several crucial occasions, to express to Australia the concerns about the financing of the rehabilitation that it eventually brought before the court. ${ }^{394}$ oda agreed with 
Australia's contention that Nauru waived its claim to rehabilitation of the worked-out phosphate lands by failing to reserve the claim in the 1967 Agreement between the States. ${ }^{395}$ He further pointed out that Nauru was totally silent on the issue of rehabilitation on the date of its independence. ${ }^{396}$ This continued silence, Oda argued, leads one to the conclusion that Nauru waived the claim to rehabilitation of the lands. ${ }^{397}$

Oda upheld Australia's preliminary objection based on the passage of time between Nauruan independence and its submission of the Application to the Court. Again he noted that no claim was put forward when it should have been, at the time of Nauruan independence. ${ }^{398}$ Oda found, through an examination of the facts, that Nauru had kept silent on the matter for fifteen years and therefore violated the principle of good faith by failing to act with due diligence. ${ }^{399}$ Oda concluded his decision by stating that he hoped Australia will consider assisting Nauru in the rehabilitation as the latter is a newly independent state and thus in a vulnerable natural and social situation. ${ }^{400}$

Oda's meticulous attention to the factual history of 
the dispute is characteristic of a common law approach to discovering the law. This was the preliminary phase of the case and the Court wasn't asked to decide on the merits, but justices still must determine what law governs the dispute and apply it to the dispute to determine if the Court has jurisdiction over the dispute. Like the majority, Oda looked to the correspondence between Nauru and Australia and the United Nations to discover whether there was evidence for the claim that Australia had breached its international obligations. Oda applied the law in a way similar to the majority. He did not go beyond the boundaries established by international law, as would a traditional common law judge, by attempting to create law that did not already exist in written agreements or state practice. On the other hand, his encouragement to Australia to assist Nauru in the rehabilitation of the phosphate lands might be regarded as evidence of a common law orientation towards judicial decision which emphasizes creativity and independent thought.

It appears that oda was divided from the majority by virtue of the way he interpreted the facts. When he 
looked at the history of the dispute, he saw something very different than what was seen by the rest of the Court; where the Court saw Nauru making repeated attempts to resolve the disagreement, Oda saw silence. Therefore it was in the interpretation of the facts, not the importance of them, that led to Oda's dissent.

By nine votes to four the Court rejected Australia's preliminary objection based on the fact that New Zealand and the United Kingdom were not parties to the proceedings. The dissenters were Jennings, Oda, Ago, and Schwebel. Jennings, a common law educated judge from Britain, applied the formula from the case of the Monetary Gold Removed from Rome in $1943^{401}$ which limits the Court's exercise of its jurisdiction over a case if a third state's "legal interests would not only be affected by a decision, but would form the very subject-matter of the decision." 402 Jennings asserted that the legal interests of the United Kingdom and New Zealand would form the subject matter of any decision in Nauru's case against Australia and therefore the Court lacked jurisdiction. ${ }^{403}$

Jennings noted that if the Court was to find 
Australia liable for breaching its international legal obligations, an assessment of damages would be made. Since New Zealand and the United Kingdom were part of the $A A$ and the BPC, he argued, any assessment would clearly and unavoidably be a decision in respect of the legal interests of the other two states. ${ }^{404}$ He reasoned that the Court lacked the jurisdiction to make a decision affecting the other two states. ${ }^{405}$

Jennings's dissent is typical of the common law tradition. He discovered the rule of law in a prior court ruling and applied it to the present dispute to reach a conclusion about these particular circumstances. He mentioned three of the "salient instances of the inextricable involvement," of the legal interests of the United Kingdom and Australia and ruled that these facts alone lead to the conclusion that the subject-matter of the decision would be formed by the legal interests of the two states. ${ }^{406}$

Although one might be able to demonstrate that Jennings's discovery of the law was determined by his legal education, his application of the law was more representative of the civil law tradition. His dissent 
was very brief and to the point and it lacked any evidence that he perceived his role as creative of law. It appears that he did not expand his reasoning to include his own personal beliefs about the law or this particular dispute.

One must not overlook the fact that Jennings' native state, the U.K., had an interest in this case. As the United Kingdom was one of the Parties potentially affected by the Court's decision, in all likelihood the British government would like to have seen the Court dismiss the case. Even if this judgment was not directly applicable to the United Kingdom or New Zealand, one would suppose that if Nauru was victorious at the ICJ, a suit against the other two countries might be forthcoming and that the judgment against those two states would be similar to the one against Australia.

Some observers might infer from this fact that Jennings's opinion was politically motivated. They would probably argue that Jennings felt it his duty to uphold the interests of the United Kingdom. They might contend, moreover that his own political convictions paralleled the position of the British government and thus he may 
have been disallowed from ruling in favor of Nauru. However, their claims would be difficult to support as Jennings's opinion does not provide any evidence indicating that he voted in opposition to the majority out of devotion to his government. One would be hardpressed to find any statements or insinuations in the opinion which would justify such a conclusion.

The third common law dissenter, Justice Schwebel, argued that private law sources and analogies are unhelpful in international law where jurisdiction is consensual. ${ }^{407}$ Schwebel turned to ICJ cases to determine the law on the question of involving New Zealand and the United Kingdom in the dispute. Schwebel pointed to his dissent in Nicaragua V.U.S. ${ }^{408}$ and to the Land, Island and Maritime Frontier Dispute ${ }^{409}$ between El Salvador and Honduras as supportive of the principle that if the legal interests of a third state will not merely be affected but effectively determined by the Court's judgment, the Court should not proceed to give judgment in the absence of that third state. ${ }^{40}$ Looking towards the facts, Schwebel found that all of Australia's actions with regard to the governance of Nauru were on behalf of the 
three states collectively. ${ }^{411}$ He concluded that a judgment on Australian responsibility would be a judgment on the responsibility of the United Kingdom and New Zealand.

Judge Schwebel's opinion is a classic example of the common law style. Although he disapproves of the Court's use of private law sources and analogies, he applies the common law method of examining cases to discover the law. More significant is the fact that Schwebel chose his own dissenting opinion in Nicaragua V.U.S. ${ }^{412}$ as supportive of his legal position in this case. In the domain of international law, cases do not establish precedent, and moreover, dissenting opinions are not deemed to be creative of law. Schwebel's reference to his own dissenting opinion is indicative of a judge who views his own decisions, even if they are dissents, as noteworthy and as potential rules and principles of law. As I pointed out in Chapter Two, in common law systems it is not uncommon for dissenting opinions to eventually become the law of the land as standards, norms, and ideals change. Thus in common law systems, dissenting opinions are not only regularly written but are highly valued. Schwebel's reliance on his own dissenting opinion in 
a previous case, an opinion which was incidentally the source of much controversy in the international legal community, is a clear example of a common law discovery and application of the law. Schwebel discovered the law through an analysis of the cases and in typical common law form displayed independence and authority by supplying his own opinion, which was not accepted as binding in the first case, as binding in the present case. He devoted much time in this dissenting opinion to an explanation of his position in the Nicaragua case, again evidencing a belief that his independent opinion is one that has significant consequences for international law.

It appears in this case, then, that Schwebel discovered and applied the law in a manner consistent with his legal education and training. His decision hinges entirely on terms of past PCIJ and ICJ rulings and the facts of this particular dispute. And he expands the international judicial role to allow for more creativity, authority, and independence.

The final dissenter, Judge Ago, is an Italian educated in the civil law. Ago objected to the Court's 
decision regarding the absence of the United Kingdom and the New Zealand because as he saw it there existed an insurmountable contradiction between two facts: 1)Nauru brought suit against Australia alone and; 2) the task of administering Nauru was entrusted to three distinct sovereign states. ${ }^{413}$ Ago argued that the authority conferred by the United Nations was done on the basis of the legal equality of the three powers. ${ }^{414}$ He conceded that Australia may have, as other judges have pointed out, discharged more tasks than the other two states but argues that this fact can "in no way affect the fundamental situation of equality of rights and obligations between three partners.." 415

Ago contended that Nauru had every reason to bring action against all three of the states as opposed to Australia alone. ${ }^{416}$ He pointed out that Nauru chose not to sue all of the states and thus reasoned that a ruling by the Court on these claims against Australia "will, inevitably, affect the legal situation of the two other states, namely, their rights and obligations." $417 \mathrm{He}$ concluded that a judgment by the court would deprive it of its "indispensable consensual basis." 418 
Ago's civil law roots are manifest in his repeated concern with the rights and obligations of Australia and New Zealand. However, he never clearly explicated those principles, as would a traditional civil law judge. Additionally, he stated at the outset that his argument hinges on the existence of two "insurmountable contradictory facts". It is these facts, he argued, that lead him to a conclusion different from the majority.

Ago's application of the law also fails to conform neatly into one legal tradition. His opinion constitutes a firm dissent, an exercise discouraged in both the civil law and socialist law traditions. However, it doesn't evidence the independence, creativity, and authority on display in Schwebel's opinion. Ago, like Oda, seems to have interpreted the facts in such a way as to come to a conclusion in opposition to that of the majority.

The analysis of this case is similar to the analyses of the cases before it: it appears that with the exception of two justices, Schwebel and perhaps Jennings, the justices did not discover and apply the law in a manner consistent with the legal traditions under which they were educated. The votes alone represent clear and 
convincing evidence that legal tradition did not determine how the justices discovered and applied the law. The analysis provides further support for this conclusion.

One noteworthy observation is the solidarity of the judges educated and trained in civil law states. With one exception, Ago, they all voted with the majority. This observation may not shed much light on the judicial decision-making process as the discovery and application of the law in the judgment was not reflective of only civil law.

The only two judges on the Court educated and trained exclusively in the common law tradition, Jennings and Schwebel, dissented from the majority. Both of these opinions exhibited definite common law predispositions. Jennings appeared to have discovered the law in typical common law fashion, through an application of case law, but doesn't seem to have adhered to that tradition when applying the law. I also noted above that one must consider the argument that Jennings's decision was dictated by the fact that the United Kingdom had an ostensive interest in the case. I attempted to refute 
this argument by demonstrating that there was no evidence to support it.

Schwebel appears to discover and apply the law in quintessential common law style. One might argue that his opinion was also the product of political interests and that the United States's alliances with the United Kingdom, Australia, and New Zealand dictated Schwebel's decision-making. This thesis appears to be refuted, however, by Schwebel's previous dissent in the Nicaragua case which, he argues, is consistent with his dissent in this case. If Schwebel's position is truly consistent, then it appears that he may have carved out a legal position that was applicable to both cases.

In the following chapter I will make some concluding remarks about the findings from these case studies, the controversy over the convergence or divergence of the civil and common law traditions, and how judicial decision at the World Court may or may not shed light on that debate. 


\section{CHAPTER SIX}

\section{CONCIUSION}

I noted in Chapter one that this project does not aim to determine "in what exact proportion" legal tradition might influence judicial decision at the International Court of Justice. Nor is this thesis an effort to detect all of the factors which possibly influence an ICJ judge's thinking. Instead, the aim is a more modest one.

Again the purpose of this exercise was to ascertain to what extent the legal tradition under which an ICJ justice was educated and trained in the law determines how she or he decides an international legal dispute. The best possible approach to answering this question might be to analyze each and every case the ICJ has decided in the manner I have done here. However, the limitations associated with a thesis project precluded me from analyzing nearly 80 court cases.

This exploratory exercise constitutes a less 
comprehensive, yet still informative method, of discovering whether and to what extent legal tradition determines how an ICJ justice finds and applies the law. Although I did not examine each and every case decided by the Court, the cases analyzed in the foregoing pages are the most divisive of the era in which they were decided, i.e., they represent the widest split of votes, and thus were the most likely cases to reflect differences between judicial decisions based on legal tradition. In other words these three cases constitute a sample from all of the ICJ cases that, when put to analysis, can provide an answer to the question of this project without prejudicing the outcome of the study.

The analysis of the Right of Passage case yielded Iittle evidence to support the claim that legal tradition determines how an ICJ judge finds and applies the law. Although there was evidence to indicate that the civil law dissenters may have employed methods of discovering and applying the law traceable to their legal education and that the Socialist judges may have disagreed because of their different legal educations, the decision by the majority and the opinions of the common law dissenters 
seemed to be more reflective of the rules of international law which have created for the justices a particular role with identifiable constraints. Moreno Quintana's dissent lent further support to the claim that legal tradition was not an important variable in judicial decision as his opinion seemed to be motivated by political convictions rather than legal rules and principles. Thus, if the legal tradition under which an ICJ justice was educated and trained mattered to the judicial decision-making process in this dispute, it was only in the case of four justices: two civil law dissenters and two socialist dissenters.

The analysis of the decisions in the North Sea Continental Shelf Cases produced similar results. Of the fifteen permanent justices who contributed to that decision, only two, Morelli and Jessup, seemed to find and apply the law in a way reflective of the legal tradition under which they were educated and trained. The rest of the justices appeared to have been guided by the rules of international law that have been laid down by the states. They found the law through an analysis of state practice and kept their function limited to a 
direct answer to the question asked by the Parties to the dispute.

The same can be said of the Court in the Case of the Phosphate Lands in Nauru. Only two of the justices, Jennings and Schwebel, appeared to have been discovering the law in a fashion typical of their legal tradition, the common law. And only one of them, Schwebel, applied the law in common law style. The majority, like the majorities in the previous two cases, discovered the law like common law jurists, looking to concrete facts, but applied in traditional civil law fashion, modestly and with restraint.

If these three cases are truly representative of how the justices on the ICJ decide cases, then it appears that legal tradition plays, at the most, a very minimal role in judicial decision-making at the ICJ. In each of the cases the majority employed methods from more than one legal tradition; thus most of the justices on the Court did not find and apply the law in a manner reflective of the legal tradition under which they were educated and trained.

Nonetheless, the fact that most of the justices at 
the ICJ were not influenced by legal tradition in their decision does not mean that legal traditions have no significance at the World Court. In two of the cases the American judge adjudicated in traditional common law style. In one case the British judge discovered the law as would a common law judge. In two of the cases at least one civil law judge employed tactics of legal reasoning representative of his legal tradition. And in one case the divergence of two Socialist judges might be explained by reference to their distinct legal education and training.

The analysis of the three cases at the ICJ leads one to conclude that while the legal tradition under which a judge is educated and trained may not determine how she or he discovers and applies the law in most cases, it may in a few cases influence (to what degree is unknown) how a judge at the ICJ reasons and delivers a decision. In other words, legal tradition may not be a significant variable in judicial decision-making, however, one should not hastily disregard it in every case as unimportant. One might also conclude from the analysis that political or national interest is not a significant 
variable in judicial decision at the ICJ. Only one justice in the entire study, Moreno Quintana in the Right of Passage Case, evidenced a concern with the political implications of his vote and, possibly, voted accordingly. I raised the possibility that critics of Judge Jennings's vote in the Phosphate Lands Case might attribute his decision to national interest, but I also noted that his opinion did not substantiate these claims. One pattern that stands out in these three cases involves the judgments of the majority of the Court. In each of these cases the judgment manifests a reliance on common law methods for discovering the law and civil law, and perhaps socialist law, techniques for applying the law. In each of this cases the court finds the law through an interpretation and analysis of the facts of the case and, if they exist, state practice and international agreements on the legal issue under scrutiny. In its search for the law, the Court appears to worry less about what justice requires or what, in principle, is the "correct" answer to the problem and more about the history of the legal relations between the states. 
On the other hand, the majority in each of these cases applies the law in civil law style. There is no evidence to support the claim that the majority tried to create law or establish international precedent. Nor is there any indication in the judgments of a majority that perceives itself as highly independent or influential. Rather, the majority seems to perceive its role as relatively limited. In each of the cases the judgment supplies an answer to the question or disagreement posed by the Parties; the majority appears to try to restrict its reach to those legal issues the Parties ask the court to resolve and which the court sees as within its jurisdiction.

When one considers the context in which the justices at the ICJ are adjudicating legal disputes, this pattern on display in their judgments may not be surprising. Because international law and international legal institutions, like the ICJ, govern states and are created and interpreted by states, the world Court faces constraints that domestic courts may not. It faces the dilemma of trying authoritatively to solve disputes between states which have, through the United Nations, 
created the Court and have the authority to abolish the it. If states cherish their sovereignty as much as most observers of international politics argue they do, then the Court must walk a fine line between upholding international law in the face of violations by states and respecting the states's right of sovereignty. An activist, independent World Court that ignores the realities of international politics might effectively create its own demise. The Court's emphasis on the concrete facts of the case and its unwillingness to answer questions not asked of it seems understandable then, given its position in the international legal structure.

\section{ARE COMMON ILAW \& CIVIL ILAW REALLY DIFFERENT?}

In Chapter Two I introduced and discussed the debate over the convergence and/or divergence of the common law and civil law traditions and suggested that the case studies might shed light on the debate. It seems that the ICJ might be an appropriate context within which to draw some limited conclusions about this debate as the 
World Court is perhaps one of the only tribunals with judges from different legal traditions deciding the same case.

Although the judgments of these three cases, if they reflect a court constrained by international law as opposed to a Court applying methods from two traditions, may not help settle the debate, the breakdown of votes might. As we saw in each of the cases, the majority represented a combination of civil law and common law judges. In none of these cases did the civil law judges build a coalition opposed to the common law judges or vice-versa; the votes did not fall along lines of legal tradition. In all of these cases, civil law and common law judges agreed on many questions of law, and in many cases, discovered and applied the law in a similar manner.

Still, the few instances of justices appearing to have decided a dispute in accordance with their respective legal tradition may suggest that the two traditions haven't entirely converged. It seems, in these opinions, that the methods for discovering and applying the law in civil and common law systems have not 
entirely converged. Jessup and Morelli's opinions in the North Sea Cases and Schwebel's opinion in the Phosphate Lands Case provide evidence for the claim that the differences between common law and civil law legal systems persist. Perhaps Schwebel's decision in the latter case is more pertinent as it is more recent.

Although I am reluctant to draw any further conclusions regarding this debate because of the differences between international and domestic law, the findings here indicate that one might want to take seriously the arguments of those individuals like Merryman and Zweigert and Kotz who argue that the common law and civil law traditions continue to reveal differences while adopting many of the other traditions' methods. Their positions are supported by the fact that civil law and common law jurists at the ICJ can agree on an eclectic method of adjudicating disputes while other justices at the world court continue to rely on methods and techniques of discovering and applying the law that are characteristic of their respective legal traditions. Most justices appear to be able and willing to utilize methods from either tradition while others prefer, at 
least in their decision in these cases, to employ what they have learned from their legal education and training.

\section{Are These Findings Important?}

Even though this study did not reveal the significant variables involved in judicial decisionmaking at the ICJ, it has made a contribution to the body of literature on judicial behavior at the ICJ. Indeed, if one wants to understand how decisions are made at the ICJ, one needs to know how they are not made. Armed with the knowledge that certain variables are of less or no significance to decision-making at the ICJ, scholars and lawyers interested in how members of the ICJ reach decisions are that much closer to being able to offer an explanation of the Court's judgments. If these individuals know that the legal tradition under which a justice at the ICJ was educated and trained does not determine how she or he will find and apply the law in an international legal dispute, then one would expect to see that finding reflected in their arguments. Although this study rules out legal tradition as a significant variable 
in decision making at the ICJ, one is left answering the question: How do these justices decide the cases brought before them? 


\section{NOTES}

\section{CHAPTER ONE}

${ }^{1}$ See, generally, John T. Noonan, Jr. and Kenneth I. Winston (eds.), The Responsible Judge: Readings in Judicial Ethics (Westport, CT: Praeger Publishers, 1993); H.K. Lucke, "The Common Law: Judicial Impartiality and Judge-Made Law," 98 Law Quarterly Review (1982) 51, 5193; See, also, Edith Brown Weiss, "Judicial Independence and Judicial Impartiality: A Preliminary Inquiry," in Lori F. Damrosch (ed.), The International Court of Justice at a Crossroads? (Dobbs Ferry, NY: Transnational Publishers, Inc., 1987), pp. 123-154.

${ }^{2}$ Not surprisingly, this argument has been advanced by judges themselves. See, Manfred Lachs, "A Few Thoughts on the Independence of judges of the International Court of Justice," 25 Columbia Journal of Transnational Law (1987) 593; William O. Douglas, The Court Years 19391975 (New York: Random House, 1980), ch. 2. Also, Robert E. Keeton, Judging (St. Paul: West Publishing Co., 1990), pp. 1-27.

${ }^{3}$ See, Peter J. Van Koppen and Jan Ten Kate, "Individual Differences in Judicial Behavior: Personal

Characteristics and Private Law Decision-Making, " 18 Law and Society Review (1984) 224; Lyndell Prott, The Latent Power of Culture and the International Judge (Abingdon,

Oxon: Professional Books, 1979).

For a slightly different view, see, Joseph C.

Hutcheson, Jr., "The Judgment Intuitive: The Function of the 'Hunch' in Judicial Decision," 14 Cornell Law Quarterly (1929) 274 .

4 See, Prott, The Latent Power of Culture and the International Judge; Manfred Lachs, "Thoughts on the Recent Jurisprudence of the International Court of Justice," 4 Emory Intnl Law Review (1990) 77, 77-94; Edith Brown Weiss, "Judicial Independence and Impartiality: A Preliminary Inquiry," in Damrosch, pp. 
123-154; David P. Forsythe, "The International Court of Justice at Fifty," in A.S. Muller, D. Raic, and J.M.

Thuranszky (eds.), The International Court of Justice: Its Future Role after Fifty Years (The Hague: Martinus Nijhoff Publishers, 1997), pp. 385-406; William Samore, "The World Court Statute and Impartiality of the Judges, 34 Nebraska Law Review (1955) 618; Samore, "National Origins vs. Impartial Decisions: A Study of World Court Holdings," 34 Chicago-Kent Law Review (1956) 193; Il Ro Suh, "Voting Behavior of National Judges in International Courts," 63 AJIL (1969) 224; Daniel D. Nsereko, "The International Court, Impartiality, and Judges Ad Hoc, " 13 IJIL (1973) 207; Herscht Lauterpacht, The Function of Law in the International Community (Hamden, CT: Archon Books, 1966), pp. 202-241; and G.J. Terry, "Factional Behavior on the International Court of Justice: An Analysis of the First and Second Courts (1945-1951) and the Sixth and Seventh Courts (1961-1967)," 10 Melbourne U.L. Rev. (1975) 59 .

${ }^{5}$ The Right of Passage Case, 1960 I.C.J. Reports 6.

${ }^{6}$ The North Sea Continental Shelf Cases, 1969 I.C.J. Reports 3

${ }^{7}$ The Case Concerning the Phosphate Lands in Nauru, 1992 I.C.J. Reports 240

${ }^{8}$ Gary L. Scott, Heather MacGregor Bothwell, and Jennifer Pennel1, "Recent Activity Before the International Court of Justice: Trend or Cycle?" 2 ILSA Journal of Intn'l \& Comp. Law (1997) 1 .

${ }^{9}$ Arthur Eyffinger, The International Court of Justice: 1946-1996 (The Hague: Kluwer Law International, 1996), pp. $374-384$.

${ }^{10}$ See Prott generally.

${ }^{11}$ See note 4.

${ }^{12}$ Prott, p. 199.

${ }^{13}$ See, e.g., Ruggero J. Aldisert, "Rambling Through 190 
Continental Legal Systems," 43 Univ. of Pittsburgh L. Rev. (1982) 935; and Rene David and John E.C. Brierly, Major Legal Systems in the World Today (London: Stevens \& Sons, 1968), p. 9

${ }^{14}$ Ibid.

${ }^{15}$ John H. Merryman, The Civil Law Tradition (Stanford, CA: Stanford University Press, 1969.), p. 2 .

${ }^{16}$ David \& Brierly, p. 9.

17 Craig M. Lawson, "The Family Affinities of Common-Law and Civil-Law Legal Systems," 6 Hastings Intn'l \& Comp. Law Rev (1982) 85.

${ }^{18}$ Ibid. , p. 88 .

${ }^{19} \mathrm{John}$ Henry Merryman, "On the Convergence (and Divergence) of the Civil Law and the Common Law," 17

Stanford J. IntnI Law (1981) 357, 381.

${ }^{20}$ Ibid.

${ }^{21}$ Lawson, p. 89.

${ }^{22}$ Ibid.

${ }^{23}$ Ibid.

${ }^{24}$ Ibid.

${ }^{25}$ Ibid., pp. 90-91. Merryman, "On the Convergence (and

Divergence) of the Civil Law and the Common Law," p. 385 .

${ }^{26}$ Merryman, "On The Convergence (and Divergence) of the Civil Law and the Common Law," p. 385.

${ }^{27}$ Ibid. , p. 380 .

${ }^{28}$ Lawson, p. 91.

${ }^{29}$ David \& Brierly, p. 10. 
${ }^{30}$ Ibid., p. 11

${ }^{31}$ Ibid; Lawson, p. 91.

${ }^{32}$ Lawson, p. 91.

${ }^{33}$ Ibid.

${ }^{34}$ Ibid.

${ }^{35}$ Merryman, The Civil Law Tradition, p. 1.

${ }^{36} \mathrm{John}$ H. Merryman and David S. Clark, Comparative Law:

Western European and Latin American Legal Systems: Cases and Materials (New York: The Bobbs-Merrill Company, Inc. Publishers, 1978), p. 4.

${ }^{37}$ Ibia.

${ }^{38}$ Ibid.

${ }^{39}$ Ibid. , p. 5.

${ }^{40}$ Ibid., p. 6 .

${ }^{41}$ Lawson, $p$.

${ }^{42}$ See, generally, Merryman, "On the Convergence (and Divergence) of the Common Law and the Civil Law." See also, Phillipe Bruno, "The Common Law from a Civil Lawyer's Perspective," Richard A. Danner, Marie-Louise H. Bernal (eds.), Introduction to Foreign Legal Systems (New York: Oceana Publications, Inc., 1994), p 7 ; and Aldisert.

${ }^{43}$ Lawson, p. 88 .

${ }^{44}$ Ibid. , p. 87.

${ }^{45}$ And as Brierly explains, a set of criteria is necessary. "To detect the existence of legal families," he maintains, "it is certainly useless to attempt to select only one criterion." p. 12. 
${ }^{46}$ Lawson, pp. 129-131.

${ }^{47}$ Merryman, p. 6 .

${ }^{48}$ Merryman in Merryman and Clark, p. 3.

\section{CHAPTER TWO}

${ }^{49} \mathrm{~K}$. Zweigert and $\mathrm{H}$. Kotz, An Introduction to Comparative Law (Oxford: Clarendon Press, 1992), p. 278.

${ }^{50}$ Merryman, The Civil Law Tradition, p. 7; Mary Ann Glendon, Michael Wallace Gordon, and Christopher Osakwe, Comparative Legal Traditions (St.Paul, MN: West Publishing Co., 1985), P. 40; and James G. Apple and Robert P. Deyling, A Primer on the Civil Law System (Federal Judicial Center, 1995), p. 5 .

${ }^{51}$ Merryman, The Civil Law Tradition, p. 10.

${ }^{52}$ Ibid.

${ }^{53}$ Ibid.

${ }^{54}$ Ibid.

${ }^{55}$ Ibid. , p. 21.

${ }^{56}$ Merryman, The Civil Law Tradition, p. 11.

${ }^{57}$ Ralf Rogowski (ed.), Civil Law The International Library of Essays in Law \& Legal Theory, Legal Cultures 10 (New York: New York University Press, 1996), p. xi.

${ }^{58}$ Merryman, The Civil Law Tradition, pp. 18-19. ${ }^{59}$ Ibid.

${ }^{60}$ Ibid. 
${ }^{61}$ Peter G. Stein, "Roman Law, Common Law, and Civil Law," 66 Tulane Law Review (1992) 1591, 1595.

${ }^{62}$ Merryman, The Civil Law Tradition, pp. 13-14.

${ }^{63}$ Zweigert and Kotz, pp. 266-267.

${ }^{64}$ Ibid. See also the observations of a common 1aw judge on civil law legal systems in Ruggero J. Aldisert,

"Rambling Through Continental Legal Systems," 43 Univ. of Pittsburgh Law Review (1982) 935, 952.

${ }^{65}$ Phillipe Bruno, "The Common Law from a Civil Lawyer's Perspective," in Richard A. Danner, Marie-Louise H.

Bernal (eds.), Introduction to Foreign Legal systems

(New York: Oceana Publications, Inc., 1994), p. 7.

${ }^{66}$ Ibid., p. 2.

${ }^{67}$ Ibid. , p. 2 .

${ }^{68}$ Ibid.

${ }^{69}$ Bruno, p. 8 .

${ }^{70}$ Ibia.

${ }^{71}$ Ibid.

${ }^{72}$ Stein, p. 1596

${ }^{73}$ Ibid. , p. 1600.

${ }^{74}$ Aldisert, p. 937. Aldisert is an American judge who has spent much time in European courts examining the differences between the common law and civil law systems.

${ }^{75}$ Zweigert and Kotz, p. 188.

${ }^{76}$ Mary Ann Glendon, Michael Wallace Gordon, and Christopher Osakwe, Comparative Legal Traditions (St. Paul, MN: West Publishing Co., 1985), p. 122. 
${ }^{77}$ Mirjan Damaska, "A Continental Lawyer in an American Law School: Trials and Tribulations of Adjustment, "partially reprinted in John H. Merryman and David S. Clark (eds.), Comparative Law: Western European and Latin American Legal Systems (Indianapolis: The Bobbs-Merrill Company, Inc., 1978), pp. 397-406.

${ }^{78}$ Ibid.

${ }^{79}$ Ibid.

${ }^{80}$ Merryman, "Legal Education There and Here: A Comparison," in Merryman and Clark, pp. 406-415.

${ }^{81}$ Glendon et al., p. 123 .

${ }^{82}$ Ibid.

${ }^{83}$ Glendon et al., p. 123.

${ }^{84}$ Damaska, p. 402 .

${ }^{85}$ Ibid.

${ }^{86}$ Ibid.

${ }^{87}$ Merryman, "Legal Education There and Here: A Comparison," in Merryman and Clark, pp. 406-415.

${ }^{88}$ Damaska, p. 402 .

${ }^{89} \mathrm{Glendon}$ et al., p. 123.

${ }^{90}$ Ibid., p. 150 .

${ }^{91}$ Stein, p. 1597; Merryman, The Civil Law Tradition, p. 36; Zweigert and Kotz, p. 129; Glendon et al., p. 156; Craig Lawson, "The Family Affinities of Common-Law and Civil-Law Legal Systems," 6 Hastings Int'1 \& Comp. Law Rev (1982) 85, 127.

${ }^{92}$ Merryman, The Civil Law Tradition, p. 39. 
${ }^{93}$ Merryman, The Civil Law Tradition, p. 36.

${ }^{94}$ Ibid.

${ }^{95}$ Ibid.

${ }^{96}$ Ibid.

${ }^{97}$ Ibid.

${ }^{98}$ Merryman, The Civil Law Tradition, p. 37-38.

${ }^{99}$ Stein, p. 1597. Judges in France have a particularly limited function. Recall the revolutionary reform effectively stripping the judiciary of law-making power. Aldisert observes that the role of the judiciary has not expanded substantially since the reform. (p. 936.)

${ }^{100}$ Ibid. See also Aldisert, p. 952.

${ }^{101}$ Ibid.

${ }^{102}$ Zweigert and Kotz, p. 272.

${ }^{103}$ Zweigert and Kotz, p. 273.

${ }^{104}$ Merryman, The Civil Law Tradition, p. 38; Stein, p. 1597 .

${ }^{105}$ Stein, p. 1597.

${ }^{106}$ Hanns Hohman, "The Nature of the Common Law and the Comparative Study of Legal Reasoning," 38 Amer. J. of Comp. Law (1990) 143, 166.

${ }^{107}$ Ibid. , pp. 166-67.

${ }^{108}$ Merryman, The Civil Law Tradition, p. 37.

${ }^{109}$ Ibid., pp. 37-38. "His function is merely to find the right legislative provision, couple it with the fact situation, and bless the solution that is more or less automatically produced from the union.." 
${ }^{110}$ Ibid., p. 38

${ }^{111}$ Ibid.

${ }^{112}$ To illustrate his point Merryman asks, "Who knows the name of a civil law judge?" The Civil Law Tradition, $p$. 38 .

${ }^{113}$ Zweigert and Kotz., p. 227

${ }^{114}$ Ibid., 227-228. The common law influence is not as significant in African countries; they are primarily governed by customary African law and in some cases the rules of Islamic laws (p. 238)

${ }^{115}$ Rene David and John E.C. Brierly, Major Legal Systems in the World Today (London: Stevens \& Sons, 1968), $p$. 262; Zweigert and Kotz, p. 189; and Glendon et al., pp. 69-70.

${ }^{116}$ David \& Brierly, p. 262.

${ }^{117}$ Ibid.

${ }^{118}$ Ibid., p. 265. Also, Zweigert and Kotz, p. 190.

${ }^{119}$ Ibid.

${ }^{120}$ Merryman, The Civil Law Tradition, p. 52; and Zweigert and Kotz, p. 265 .

${ }^{121}$ Zweigert and Kotz, p. 204.

${ }^{122}$ Ibid., p. 205

${ }^{123}$ Ibid.

${ }^{124}$ Ibid.

${ }^{125}$ Ibid., p. 207.

${ }^{126}$ Ibid. 
${ }^{127}$ Ibid.

${ }^{128}$ A.G. Chloros, "Common Law, Civil Law and Socialist Law: Three Leading Systems of the World, Three Kinds of Legal Thought," in Csaba Varga (ed.), Comparative Legal

Cultures (New York: New York University Press, 1992), p. 85 .

${ }^{129}$ Ibid., p. 87. Also, Alan Brudner, The Unity of the Common Law: Studies in Hegelian Jurisprudence (Berkeley: The University of California Press, 1995), pp. 2-3.

${ }^{130}$ Chloros, p. 86 .

${ }^{131}$ Zweigert and Kotz, p. 202.

${ }^{132}$ Glendon et. al, p. 564.

${ }^{133}$ Ibid., p. 268; Chloros, p. 85.

${ }^{134} \mathrm{Glendon}$ et. al, p. 268.

${ }^{135}$ Ibid.

${ }^{136}$ Ibid.

${ }^{137}$ Bruno, p. 9.

${ }^{138}$ Ibid.

${ }^{139}$ Ibid.

${ }^{140}$ Zweigert and Kotz, p. 266.

${ }^{141}$ Merryman, in Merryman and Clark, p. 408.

${ }^{142}$ Glendon et a1., p. 123.

${ }^{143}$ Stein, p. 1600.

${ }^{144}$ Ibid. 
${ }^{145}$ Ibid.

${ }^{146}$ Merryman in Merryman and Clark, p. 414.

${ }^{147}$ Stein, p. 1596 .

${ }^{148}$ Merryman, The Civil Law Tradition, p. 35.

${ }^{149}$ Ibid.

${ }^{150}$ zweigert and Kotz, p. 218.

${ }^{151}$ Ibid. , p. 219.

${ }^{152}$ Zweigert and Kotz, p. 217.

${ }^{153}$ Merryman, The Civil Law Tradition, p. 35.

${ }^{154}$ Bruno, p. 5.

${ }^{155}$ Ibia. , p. 4.

${ }^{156}$ Ibid.

${ }^{157}$ zweigert and Kotz, p. 274.

${ }^{158}$ See generally Lawson. Also, John H. Merryman, "On the Convergence (and Divergence) of the Civil Law and the Common Law," 17 Stanford J. Intnl Law (1981) 357; J.F. Garner, "The Common Law and the Civil Law," 134 New Law Journal Feb. 2, 1984, pp. 129-130; Jacob Dolinger, "A Civil Law Lawyer looks at a Common Law Lawyer's Views on Civil Law: John Henry Merryman's "The Civil Law Tradition" 17 Brooklyn J. Intn'l Law (1991) 557.

${ }^{159}$ Zweigert and Kotz, p. 278.

${ }^{160}$ Ibid., pp. $278-80$.

${ }^{161}$ Garner, p. 130 .

${ }^{162}$ Aldisert, p. 953. 
${ }^{163}$ Lawson, pp. 104-111.

${ }^{164}$ Ibid.

${ }^{165}$ Ibid., p. 99-104.

${ }^{166}$ Ibid., p. 116 .

${ }^{167}$ Ibid., p. 102 .

${ }^{168}$ Merryman, "On the Convergence (and Divergence) of the Civil Law and the Common Law," p. 387.

${ }^{169}$ Ibid.

${ }^{170}$ Mary Ann Glendon, "The Sources of Law in a Changing Legal Order," 17 Creighton Law Review (1984) 101, 124. ${ }^{171}$ Ibid.

${ }^{172}$ Merryman, "On the Convergence (and Divergence) of the Civil Law and the Common Law," pp. 371-72.

${ }^{173}$ Ibid. , p. 371-381.

${ }^{174}$ Aldisert, p. 953.

${ }^{175}$ Lawson, p. 130 .

${ }^{176}$ Ibid.

${ }^{177}$ Ibid.

${ }^{178}$ Ibid.

${ }^{179}$ Zweigert and Kotz, p. 278.

${ }^{180} \mathrm{Glendon}$ et al., p. 61 .

${ }^{181}$ Zweigert and Kotz, p. 208.

${ }^{182}$ Ibid. 
${ }^{183}$ Ibid., p. 266.

${ }^{184} \mathrm{Alice}$ Erh-Soon Taj, "The Western Legal Tradition and the Internationalization of Law, " 6 Conneticut J. of Intn1 Law (1991) 529.

${ }^{185}$ Ibid. , pp. 544-45.

${ }^{186}$ Ibid., p. 544. She argues that for these reasons common law, and not civil law, ought to be applied to international disputes.

${ }^{187}$ I would like to point out that I do not intend to discuss whether recourse to the methods of a particular legal tradition is a conscious or unconscious exercise. I am simply making the point that there is no international legal tradition comparable to the common and civil law that educates and trains its students in a distinct manner.

${ }^{188}$ It is eighty years old if we accept the 1917 October Revolution in the former U.S.S.R. as its date of origin. ${ }^{189}$ Although the years 1917-1921 have been termed the era of "legal nihilism" in the U.S.S.R., they also represent a part of the history of the Socialist legal tradition.

${ }^{190} \mathrm{Glendon}$ et. al, p. 712. For every ten people in the world in 1985, six lived under Socialist law.

${ }^{191}$ Albert J. Schmidt, "Soviet Union," in Alan N. Katz (ed.) Legal Traditions And Systems: An International Handbook (Westport, CT: Greenwood Press, 1986), p. 331. See also, W.E. Butler, Soviet Law (Stoneham, MA: Butterworths Legal Publishers, 1988), p. 29.

${ }^{192}$ Ibid. Butler notes that Marx and Engels didn't say much about law. (Butler, Soviet Law, p. 31)

${ }^{193}$ Glendon et al, p. 694

${ }^{194}$ Ibid. 
${ }^{195}$ Ibid.

${ }^{196}$ Schmidt, p. 334 .

${ }^{197}$ Glendon et al., p. 697.

${ }^{198}$ Butler, Soviet Law, p. 42.

${ }^{199}$ Ibid.

${ }^{200}$ Schmidt, p. 348 .

${ }^{201}$ Andrei Y. Vyshinsky, The Law of the Soviet state (Westport, CT: Greenwood Press, 1979), p. 6.

${ }^{202}$ Ibid. , pp. 13-15.

${ }^{203}$ Ibid. , p. 13.

${ }^{204}$ Ibid., p. 75.

${ }^{205}$ Ibid. , p. 321 .

${ }^{206}$ Ibid., p. 77.

${ }^{207}$ Ibid., p. 76.

${ }^{208}$ Glendon et al., p. 682

${ }^{209}$ Ibid. , pp . 682-83.

${ }^{210}$ Ibid.

${ }^{211}$ Ibid.

${ }^{212}$ Ibid., p. 685.

${ }^{213}$ Ibid.

${ }^{214}$ Butler, Soviet Law, p. 64.

${ }^{215}$ Ibid. 
${ }^{216}$ Ibid.

${ }^{217}$ Butler, Soviet Law, p. 67

${ }^{218}$ Leo Hecht (ed. \& trans.), The Soviet Union Through Its

Laws (New York: Praeger Publishers, 1983), p. 13.

${ }^{219}$ For a basic law degree the number of years of coursework went up to five in the mid 1940's. It has since returned to four years.

${ }^{220}$ These are the subdepartments of the faculty at Moscow State University, the higher education institution which serves as the model for all of the others throughout the Soviet Union. Hecht, p. 14.

${ }^{221}$ Glendon et al., p. 798 .

${ }^{222}$ Ibid.

${ }^{223}$ Ibid. See also, W.E. Butler, Russian Legal Theory (New York: New York University Press, 1996), p. xi.

${ }^{224}$ Ibid. , p. 801 .

${ }^{225}$ Ibid. , p. 801 .

${ }^{226}$ Ibid. , p. 806

${ }^{227}$ Schmidt, p. 343 .

${ }^{228}$ Ibid. In the Soviet Union many of the judges are women. Schmidt detects a link between this fact and the low socioeconomic status of judges.

${ }^{229}$ Ibid., p. 344. See also, Zweigert and Kotz, p. 301.

${ }^{230}$ Ibid.

${ }^{231}$ Glendon et al, p. 747 .

${ }^{232}$ Ibia., p. 748 . 
${ }^{233}$ Ibid.

${ }^{234}$ Ibid.

${ }^{235}$ Ibid.

${ }^{236}$ Ibid., p. 748 .

${ }^{237}$ Schmidt, p. 348 .

${ }^{238}$ Ibid., p. 345 .

${ }^{239}$ Ibid., p. 346 .

${ }^{240}$ Vyshinsky, p. 81.

${ }^{241}$ E.B. Pashukanis, "International Law, " in Butler, Russian Legal Theory, p. 542 .

${ }^{242}$ James Hildebrand, Soviet International Law (Buffalo: NY: William S. Hein \& Co., Inc. 1969), p. 42 .

${ }^{243}$ Ibid. , pp. 20-21.

${ }^{244}$ Ibid. , p. 22.

${ }^{245}$ Ibid., pp. 44-45. See also, D.I. Feldman, "New Trends in the Theory and Methodology of International Law," in Butler, Perestroika and International Law (Dordrecht:

Martinus Nijhoff Publishers, 1990), p. 33; Butler in same book, p. 2-3.

${ }^{246} \mathrm{G} . I$. Tunkin, Peaceful Coexistence and International Law (Moscow: Progress Publishers, 1969), pp. 20-23.

${ }^{247} \mathrm{Hildebrand}$, pp. 46-47.

${ }^{248}$ Ibid., p.p. 52-68. See also, Butler, Perestroika and International Law, p. 3.

${ }^{249}$ Unless, of course, they left the country to do their legal studies. 


\section{CHAPTER THREE}

${ }^{250}$ Arthur Eyfinnger, The International Court of Justice: 1946-1996 (The Hague: Kluwer Law International, 1996), pp. 374-392.

${ }^{251}$ For more on the role of case studies in social science research, see, John Walton, "Making the Theoretical Case," in Charles Elgin and Howard Becker (eds.), What is a Case? (NY: Cambridge University Press, 1992), pp. 121137. Walton explains that case studies "provide models capable of instructive transferability to other settings." He argues that cases "claim to represent general categories of the social world, and that claim implies that any identified case comes from a knowable universe from which a sample might be drawn. The case is one point in a sampling frame, and cases are made prepossessing the universal characteristics which they represent.

${ }^{252}$ Gary Scott, Heather MacGregor Bothwell, and Jennifer Pennel1, "Recent Activity Before the International Court of Justice: Trend or Cycle," 2 ILSA J. Intn'1 \& Comp. Law (1997) 1 .

${ }^{253}$ Ibid. , p. 8 .

${ }^{254}$ Gary Scott and Karen Csajko, "Compulsory Jurisdiction and Defiance in the World Court: A Comparison of the PCIJ and the ICJ," 16 Denver J. Intn'I Law \& Pol'Y (1988) 377, 386 .

${ }^{255}$ Scott, Bothwell, and Pennell, p. 8 .

${ }^{256}$ Ibid. , p. 10.

${ }^{257}$ Ibid, pp. 10-11. 
${ }^{258}$ Ibid., p. 11.

${ }^{259}$ Ibid.

${ }^{260}$ Ibid. , p. 4.

${ }^{261}$ See, Il Ro Suh, "Voting Behavior of National Judges in International Courts," 63 AJIL (1969) 224, 228; and

Thomas R. Hensley, "National Bias and the International Court of Justice," 12 Midwest Journal of Political

Science (1968) 568, 575 .

${ }^{262}$ Il Roh Suh, p. 230.

${ }^{263} 1960$ I.C.J. Reports 6

${ }^{264}$ Ibid, pp. 8-9.

${ }^{265}$ Ibid. , p. 9.

${ }^{266}$ Ibid. , pp. 13-14.

${ }^{267}$ Ibid. , p. 13.

${ }^{268}$ Ibid. , p. 11.

${ }^{269}$ Ibid.

${ }^{270}$ Ibid., p. 32 .

${ }^{271}$ Ibid. , p. 33.

${ }^{272}$ Ibid., p. 23.

${ }^{273}$ Ibid.

${ }^{274}$ Ibid.

${ }^{275}$ Ibid. , pp. 23-24.

${ }^{276}$ Ibid. , pp. 24-25.

${ }^{277}$ Ibid. , p. 24. 
${ }^{278}$ Ibid. , pp. 45-66.

${ }^{279}$ Ibid. , p. 33.

${ }^{280}$ Ibid. , p. 35 .

${ }^{281}$ Ibid.

${ }^{282}$ Ibid. , pp. 38-39.

${ }^{283}$ Ibid., p. 40 .

${ }^{284}$ Ibid.

${ }^{285}$ Ibid. , pp. 38-43.

${ }^{286}$ The following information on the members of the Court can be found in Arthur Eyfinnger, The International Court of Justice: 1946-1996 (The Hague: Kluwer Law International, 1996), pp. 258-339.

${ }^{287}$ Ibid., p. 44.

${ }^{288}$ State practice refers to the actions of states with regard to a particular dispute or a particular international activity. In order for state practice to be regarded as law it must be supported by an additional psychological component. Opinio juris refers to the understanding among states that a particular repeated practice has evolved into an obligatory or binding rule of law. It is not enough that states repeatedly engage in a particular practice for that practice to be regarded as law. For that practice to become law, or to be regarded as law by the ICJ for instance, it must be regarded as law by the states. See Gerhard Von Glahn, Law Among Nations: An Introduction to Public International Law (New York: MacMillan Publishing Co., 1986), p. 20 .

${ }^{289}$ Ibid., p. 89.

${ }^{290}$ Ibid.

${ }^{291}$ Ibid. , p. 90. 
${ }^{292}$ Ibid., p. 95.

${ }^{293}$ Ibid. , p. 96.

${ }^{294}$ See, e.g., Morris J. Blackman and Ronald G. Hellman (eds.), Terms of Conflict: Ideology in Latin American Politics (Philadelphia: ISHI, 1977); William R. Crawford, A Century of Latin American Thought (Cambridge: Harvard University Press, 1961); Edward J. Williams, Latin American Political Thought: A Developmental Perspective (Tucson: University of Arizona Press, 1974); and Leopoldo Zea, The Latin American Mind (Norman, oK: University of Oklahoma Press, 1963).

${ }^{295}$ Ibid.

${ }^{296}$ Ibid., p. 50 .

${ }^{297}$ Ibid., p. 51.

${ }^{298}$ Ibid. , p. 79.

${ }^{299}$ Ibid., p. 97.

${ }^{300}$ Ibid. , p. 107.

${ }^{301}$ Ibid.

${ }^{302}$ Ibid. , p. 54 .

${ }^{303}$ Comparing the right of access to international enclaved property to the right of access of enclaved land owned by a private individual, he states that "the underlying principle of recognition of such a right, in its essence, is the same. It is the principle of justice founded on reason." Ibid., p. 65.

${ }^{304}$ Ibid., p. 67. 
${ }^{305} 1969$ I.C.J. Reports 3.

306 Ibid., p. 10-11.

${ }^{307}$ Ibid., p. 25.

${ }^{308}$ Ibid. , p. 30 .

${ }^{309}$ Ibid. , p. 12 .

${ }^{310}$ Ibid. , p. 22 .

${ }^{311}$ Ibid. , p. 14.

${ }^{312}$ Ibid. , p. 54.

${ }^{313}$ Ibid. , p. 23.

${ }^{314}$ Ibid. , p. 24.

${ }^{315}$ Ibid. , p. 33.

${ }^{316}$ Ibid. , p. 33-36.

${ }^{317}$ Ibid. , pp. $42-45$.

${ }^{318}$ Ibid.

${ }^{319}$ See Arthur Eyfinnger, The International Court of Justice: 1946-1996 (The Hague: Kluwer Law International, 1996), pp. 258-339.

${ }^{320} 1969$ I.C.J. Reports, 58-66.

${ }^{321}$ Ibid. , p. 66

${ }^{322}$ Ibid. , p. 86

${ }^{323}$ Ibid. , p. 90.

${ }^{324}$ Ibid., p. 153. 
${ }^{325}$ Ibia.

${ }^{326}$ Ibid. , p. 67.

${ }^{327}$ Ibid. , p. 73.

${ }^{328}$ Ibid. , p. 82 .

${ }^{329}$ Ibid. , p. 85.

${ }^{330}$ Ibid. , p. 159.

${ }^{331}$ Ibid.

${ }^{332}$ Ibid. , p. 164.

${ }^{333}$ Ibid. , p. 233.

${ }^{334}$ Ibid. , p. 224

${ }^{335}$ Ibid. , p. 240.

${ }^{336}$ Ibid. , pp. 175-76.

${ }^{337}$ Ibid., p. 177.

${ }^{338}$ Ibid. , p. 178 .

${ }^{339}$ Ibid.

${ }^{340}$ Ibid., p. 179.

${ }^{341}$ Ibid. , p. 197.

${ }^{342}$ See, Chin Kim and Craig M. Lawson, "The Law of the Subtle Mind: The Traditional Japanese Conception of the Law," in Csaba Varga (ed.), Comparative Legal Cultures (New York: New York University Press, 1992), pp. 275-297. It might be more appropriate, and more accurate, to think of law in Japan as a symbol. See, Koichiro Fujikara (ed.), Japanese Law and Legal Theory (New York: New York University Press, 1996), pp. xvi-xvii. 
${ }^{343} \mathrm{Cf}$. Hiroshi Itoh, "How Judges Think in Japan," in Fujukura, pp. 775-804.

${ }^{344} 1969$ ICJ Reports, 203.

${ }^{345}$ Ibid. , p. 205.

${ }^{346}$ Ibid. , p. 199-201.

${ }^{347}$ Ibid. , p. 202.

\section{CHAPTER FIVE}

${ }^{348} 1992$ I.C.J. Reports 240.

${ }^{349}$ Ibid., p. 246

${ }^{350}$ Ibid.

${ }^{351}$ Ibid.

${ }^{352}$ Ibid.

${ }^{353}$ Ellen Fitzgerald, "Nauru v. Australia: A Sacred Trust Betrayed?" 6 Conn. J. Intn'l Law (1990) 209, 209.

${ }^{354}$ Ibid. , pp. 209-210.

${ }^{355}$ Ramon E. Reyes, Jr. "Nauru V. Australia: The International Fiduciary Duty and the settlement of Nauru's Claims for Rehabilitation of Its Phosphate Lands," 16 New York Law School J. of Intn'1 \& Comp. Law (1996) 3 .

${ }^{356}$ Antony Anghie, "The Heart of My Home': Colonialism, Environmental Damage, and the Nauru Case," 34 Harvard Intn'1 Law J. (1993) 445, 446.

${ }^{357}$ Ibid., p. 446 . 
${ }^{358}$ Ibid.

${ }^{359}$ Ibid. , pp. 247-250.

${ }^{360}$ Ibid. , p. 243-244.

${ }^{361}$ Ibid., p. 244.

${ }^{362}$ Ibid.

${ }^{363}$ Ibid. , p. 245.

${ }^{364}$ Ibid. , p. 247.

${ }^{365}$ Ibid. , p. 248.

${ }^{366}$ Ibid., p. 253.

${ }^{367}$ Ibid. , p. 255.

${ }^{368}$ Ibid.

${ }^{369}$ Ibid. , p. 264.

${ }^{370}$ Ibid. , pp. 268-69.

${ }^{371}$ Ibid., p. 260 .

${ }^{372}$ Ibid., p. 261.

${ }^{373}$ Ibid. , pp . 260-61.

${ }^{374}$ Ibid., p. 261.

${ }^{375}$ Ibid.

${ }^{376}$ Ibid., p. 247 .

${ }^{377}$ Ibid., p. 247.

${ }^{378}$ Ibid., p. 253. 
${ }^{379}$ Ibid.

${ }^{380}$ Ibid.

${ }^{381}$ Ibid., p. 254.

${ }^{382}$ Ibid., pp. 254-55.

${ }^{383}$ Ibid., p. 255.

${ }^{384}$ Ibid. , p. 266 .

${ }^{385}$ Ibid. , p. 265.

${ }^{386}$ Ibid., p. 266 .

${ }^{387}$ See Arthur Eyfinnger, The International Court of Justice: 1946-1996 (The Hague: Kluwer Law International, 1996 ), pp. 258-339.

${ }^{388}$ In the international legal system there is no equivalent to the principle of stare decisis that is fundamental to common law legal systems. A decision at the ICJ applies only to the particular case it addresses; there is no tradition of precedent in the ICJ. The Court may apply the reasoning and/or legal standards it created in a previous case to one it is presently deciding, however, the decision of the court in the previous case is not binding on the Parties to the present case.

${ }^{389}$ Ibid., p. 271.

${ }^{390}$ Ibid., p. 279.

${ }^{391}$ Ibid. , p. 282.

${ }^{392}$ Ibid., p. 283.

${ }^{393}$ Ibid. , pp. 284-289.

${ }^{394}$ Ibid., p. 304-24.

${ }^{395}$ Ibid. , p. 311. 
${ }^{396}$ Ibid., p. 322 .

${ }^{397}$ Ibid. , p. 311.

${ }^{398}$ Ibid. , p. 323 .

${ }^{399}$ Ibid., p. 324 .

${ }^{400}$ Ibid. , pp. 325 .

${ }^{401}$ Monetary Gold Removed from Rome in 1943, 1954 I.C.J. Reports 19.

${ }^{402}$ Ibid., p. 32 .

${ }^{403} 1992$ I.C.J. Reports 301.

${ }^{404}$ Ibid., p. 302 .

${ }^{405}$ Ibid., p. 301-02.

${ }^{406}$ Ibid., p. 301.

${ }^{407}$ Ibid. , p. 329.

${ }^{408}$ Nicaragua V. The United States, 1984 I.C.J. Reports 14. ${ }^{409}$ The Case Concerning the Land, Island and Maritime Frontier Dispute, 1990 I.C.J. Reports 92.

${ }^{410} 1992$ I.C.J. Reports 335.

${ }^{411}$ Ibid., p. 340 .

${ }^{412}$ Nicaragua $v$. The United States, 1986 I.C.J. Reports 14. ${ }^{413} 1992$ I.C.J. Reports 326.

${ }^{414}$ Ibid.

${ }^{415}$ Ibid.

${ }^{416}$ Ibid. 
${ }^{417}$ Ibid. , p. 328.

${ }^{418}$ Ibid. 


\section{WORKS CITED}

\section{Books}

Apple, James G. and Robert P. Deyling. A Primer on the Civil Law System (Federal Judicial Center, 1995)

Blackman, Morris J. and Ronald G. Hellmann (eds.) Terms of Conflict: Ideology in Latin American Politics (Philadelphia: ISHI, 1977)

Brudner, Alan. The Unity of the Common Law: Studies in Hegelian Jurisprudence (Berkeley: The University of California Press, 1995)

Butler, W.E. Soviet Law (Stoneham, MA: Butterworths Legal Publishers, 1988)

Butler, W.E. Perestroika and International Law

(Dordrecht: Martinus Nijhoff Publishers, 1990)

Butler, W.E. Russian Legal Theory (New York: New York University Press, 1996)

Crawford, William R. A Century of Latin American Thought (Cambridge: Harvard University Press, 1961)

David, Rene and John E.C. Brierly. Major Legal Systems in the World Today (London: Stevens \& Sons, 1968)

Douglas, William o. The Court Years 1939-1975 (New York:

Random House, 1980)

Eyffinger, Arthur. The International Court of Justice: 1946-1996 (The Hague: Kluwer Law International, 1996)

Fujikara, Koichiro (ed.) Japanese Law and Legal Theory (New York: New York University Press, 1996)

Glendon, Mary Ann, Michael Wallace Gordon, and Christopher osakwe. Comparative Legal Traditions (St. Paul, MN: West Publishing Co., 1985) 
Hecht, Leo (ed. \& trans.) The Soviet Union Through Its Laws (New York: Praeger Publishers, 1983)

Hildebrand, James. Soviet International Law (Buffalo, NY: William S. Hein \& Co., Inc. 1969)

Keeton, Robert E. Judging (St. Paul: West Publishing Co., 1990)

Lauterpacht, Herscht. The Function of Law in the International Community (Hamden, CT: Archon Books, 1966)

Merryman, John H. The Civil Law Tradition (Stanford, CA: Stanford University Press, 1969)

Merryman, John H. and David S. Clark, Comparative Law: Western European and Latin American Legal Systems: Cases and Materials (New York: The Bobbs-Merrill Company, Inc. Publishers, 1978)

Noon, John T., and Kenneth I. Winston (eds.) The Responsible Judge: Readings in Judicial Ethics (Westport, CT: Praeger Publishers, 1993)

Prott, Lyndell. The Latent Power of Culture and the International Judge (Abingdon, Oxon: Professional Books, 1979)

Rogowski, Ralf (ed.) Civil Law The International Library of Essays in Law \& Legal Theory, Legal Cultures 10 (New York: New York University Press, 1996)

Tunkin, G.I. Peaceful Coexistence and International Law (Moscow: Progress Publishers, 1990)

Von Glahn, Gerhard. Law Among Nations: An Introduction to Public International Law (New York: MacMillan Publishing Co., 1986)

Vyshinsky, Andrei Y. The Law of the Soviet State (Westport, CT: Greenwood Press, 1979)

Williams, Edward J. Latin American Political Thought: A Developmental Perspective (Tucson: University of Arizona Press, 1974) 
Zea, Leopoldo. The Latin American Mind (Norman, OK: University of Oklahoma Press, 1963)

Zweigert, $\mathrm{K}$. and $\mathrm{H}$. Kotz. An Introduction to Comparative Law (Oxford: Clarendon Press, 1992)

\section{Journal Articles}

Aldisert, Ruggero J, "Rambling Through Continental Legal Systems," 43 Univ. of Pittsburgh L. Rev. (1982) 935

Anghie, Antony. "'The Heart of my Home': Colonialism, Environmental Damage, and the Nauru Case," 34 Harvard Intn'I Law J. (1993) 445

Brown Weiss, Edith. "Judicial Independence and Judicial Impartiality: A Preliminary Inquiry," in Lori F. Damrosch (ed.), The International Court of Justice at a Crossroads? (Dobbs Ferry, NY: Transnational Publishers, Inc., 1987), pp. $123-154$.

Bruno, Phillipe. "The Common Law from a Civil Lawyer's Perspective," in Richard A. Danner and Marie-Louise H. Bernal (eds.) Introduction to Foreign Legal Systems (New York: Oceana Publications, Inc., 1994), p. 7 .

Chloros, A.G. "Common Law, Civil Law and Socialist Law: Three Leading Systems of the World, Three Kinds of Legal Thought," in Csaba Varga (ed.) Comparative Legal Cultures (New York: New York University Press, 1992)

Damaska, Mirjan. "A Continental Lawyer in an American Law School: Trials and Tribulations of Adjustment," partially reprinted in Merryman and Clark.

Dolinger, Jacob. "A Civil Law Lawyer Looks at a Common Law Lawyer's Views on Civil Law: John Henry Merryman's 'The Civil Law Tradition'," 17 Brooklyn J. Intn'I Law (1991) 557 
Erh-Soon Taj, Alice. "The Western Legal Tradition and the Internationalization of Law," 6 Conneticut J. of Intnl Law (1991) 529

Feldman, D.I. "New Trends in the Theory and Methodology of International Law," in Butler, Perestroika and

International Law

Fitzgerald, Ellen. "Nauru v. Australia: A Sacred Trust Betrayed?" 6 Conn. J. Intn'1 Law (1990) 209

Forsythe, David P. "The International Court of Justice at Fifty," in A.S. Muller, D. Raic, and J.M. Thuranszky (eds.) The International Court of Justice: Its Future Role after Fifty Years (The Hague: Martinus Nijhoff Publishers, 1997)

Garner, J. F. "The Common Law and the Civil Law," 134 New Law Journal Feb. 2, 1984, pp. 129-130.

Glendon, Mary Ann. "The Sources of Law in a Changing Legal Order," 17 Creighton Law Review (1984) 101

Hensley, Thomas R. "National Bias and the International Court of Justice," 12 Midwest Journal of Political Science (1968) 568

Hohman, Hanns. "The Nature of the Common Law and the Comparative Study of Legal Reasoning," 38 Amer. J. of Comp. Law (1990) 143

Hutcheson, Joseph $C$. "The Judgment Intuitive: The Function of the 'Hunch' in Judicial Decision," 14 Cornell Law Quarterly (1929) 274

Kim, Chin and Craig M. Lawson. "The Law of the Subtle Mind: The Traditional Japanese Conception of the Law," in Csaba Varga, Comparative Legal Cultures

Lachs, Manfred. "A Few Thoughts on the Independence of Judges of the International Court of Justice," 25 Columbia Journal of Transnational Law (1987) 593

Lachs, Manfred. "Thoughts on the Recent Jurisprudence of the International Court of Justice," 4 Emory Intnl Law Review (1990) 77 
Lawson, Craig M. "The Family Affinities of Common-Law and Civil-Law Legal Systems," 6 Hastings Intn'l \& Comp. Law Rev. (1982) 85 .

Lucke, H.K. "The Common Law: Judicial Impartiality and Judge-Made Law," 98 Law Quarterly Review (1982) 51

Merryman, John H. "Legal Education There and Here: A Comparison," partially reprinted in Merryman and Clark.

Merryman, John H. "On the Convergence (and Divergence) of the Civil Law and the Common Law," 17 Stanford J. Intnl Law (1981) 357

Nzereko, Daniel D. "The International Court, Impartiality, and Judges Ad Hoc," 13 IJIL (1973) 207

Pashukanis, E.B. "International Law," in Butler, Russian Legal Theory

Samore, William. "The World Court Statute and Impartiality of the Judges," 34 Nebraska Law Review (1955) 618

Samore, William. "National Origins vs. Impartial Decisions: A Study of the World Court Holdings," 34 Chicago-Kent Law Review (1956) 193

Schmidt, Albert. "Soviet Union," in Alan N. Katz (ed.) Legal Traditions and Systems: An International Handbook (Westport, CT: Greenwood Press, 1986)

Scott, Gary L. and Karen Csajko. "Compulsory Jurisdiction and Defiance in the World Court: A Comparison of the PCIJ and the ICJ," 16 Denver J. Intn'l Law \& Pol'y (1988)

Scott, Gary L., Heather MacGregor Bothwell, and Jennifer Pennell, "Recent Activity Before the International Court of Justice: Trend or Cycle?" 2 ILSA Journal of Intn'1 \& Comp. Law (1997) 1

Stein, Peter G. "Roman Law, Common Law, and Civil Law," 66 Tulane Law Review (1992) 1591

Reyes, Ramon E. "Nauru V. Australia: The International Fiduciary Duty and the Settlement of Nauru's Claims for 
Rehabilitation of Its Phosphate Lands," 16 New York Law School J. of Intn'1 \& Comp. Law (1996) 3

Ro Suh, I1. "Voting Behavior of National Judges in International Courts," 63 AJIL (1969) 224

Terry, G.J. "Factional Behavior on the International Court of Justice: An Analysis of the First and Second Courts (1945-1951) and the Sixth and Seventh Courts (19611967) 10 Melbourne U.L. Rev. (!975) 59

Van Koppen, Peter J. and Jan Ten Kate. "Individual Differences in Judicial Behavior: Personal Characteristics and Private Law Decision-Making," 18 Law and Society Review (1984) 224

Walton, John. "Making the Theoretical Case," in Charles Elgin and Howard Becker (eds.) What is a Case? (NY: Cambridge University Press, 1992)

\section{Cases}

Monetary Gold Removed from Rome in 1943, 1954 I.C.J. Reports 19

The Right of Passage Case, 1960 I.C.J. Reports 6 The North Sea Continental Shelf Cases, 1969 I.C.J. Reports 3

Nicaragua v. The United States, 1984 I.C.J. Reports 14 The Case Concerning the Land, Island and Maritime Frontier Dispute, 1990 I.C.J. Reports 14

The Case Concerning the Phosphate Lands in Nauru, 1992 I.C.J. Reports 240 